$$
\text { UNIVERSIDADE DE SÃO PAULO - USP }
$$

FACULDADE DE FILOSOFIA, LETRAS E CIÊNCIAS HUMANAS - FFLCH DEPARTAMENTO DE LETRAS MODERNAS - DLM

DOUTORADO EM ESTUDOS LINGUÍSTICOS E LITERÁRIOS EM INGLÊS

YURI JIVAGO AMORIM CARIBÉ

\title{
TRADUÇÃO, ADAPTAÇÃO E REESCRITA DA OBRA DE VIRGINIA WOOLF POR MICHAEL CUNNINGHAM EM THE HOURS (1998)
}




\title{
TRADUÇÃO, ADAPTAÇÃO E REESCRITA DA OBRA DE VIRGINIA WOOLF POR MICHAEL CUNNINGHAM EM THE HOURS (1998)
}

\begin{abstract}
Tese apresentada à banca examinadora do Departamento de Letras Modernas (DLM) da Faculdade de Filosofia, Letras e Ciências Humanas (FFLCH) da Universidade de São Paulo (USP), como exigência parcial para obtenção do título de Doutor em Letras do Programa de Estudos Linguísticos e Literários em Inglês, subárea Tradução, sob a orientação da Prof. ${ }^{a}$ Dra ${ }^{\mathrm{a}}$. Lenita Maria Rimoli Esteves.
\end{abstract}

\section{VERSÃO CORRIGIDA}

De acordo.

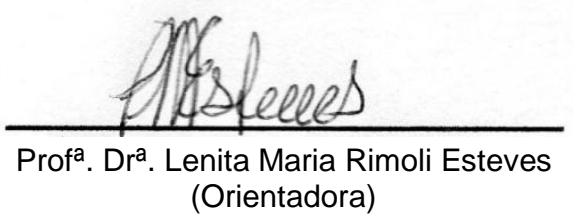


CARIBÉ, Y. J. A. Tradução, Adaptação e Reescrita da Obra de Virginia Woolf por Michael Cunningham em The Hours (1998). Tese apresentada à Faculdade de Filosofia, Letras e Ciências Humanas da Universidade de São Paulo para obtenção do título de Doutor em Letras.

Aprovado em:

Banca Examinadora

Prof. Dr. Instituição:

Julgamento: Assinatura:

Prof. Dr. Instituição:

Julgamento: Assinatura:

Prof. Dr. Instituição:

Julgamento: Assinatura:

Prof. Dr. Instituição:

Julgamento: Assinatura:

Prof. Dr. Instituição:

Julgamento: Assinatura: 
À minha família e amigos, meu porto seguro. 


\section{AGRADECIMENTOS}

Agradeço primeiramente à minha orientadora, Prof. ${ }^{\mathrm{a}} \mathrm{Dr}^{\mathrm{a}}$. Lenita Esteves, pela confiança na realização deste trabalho.

Em seguida, agradeço à minha família e amigos pela paciência e pelo carinho, em especial a Luís Eduardo, a meus pais Maria José e Antonio Julio, à Antonia Ribeiro, Charles e Larissa Caribé.

Aos amigos do GTG.

A Deus, pela certeza de que tudo acontece conforme sua vontade e no tempo certo.

Às minhas primeiras orientadoras: Prof. a Dra . Graça Targino (na graduação) e Prof. ${ }^{a}$ Dra ${ }^{a}$. Jerusa Pires (no mestrado). Também pelo apoio, incentivo e troca de ideias com a querida amiga Prof. ${ }^{a}$ Dr ${ }^{\mathrm{a}}$. Maria do Socorro Reis Cosme (UFPI).

A todos os meus colegas de trabalho, sem exceção. Também agradeço de forma especial à coordenadora Luciana Ginezi pela confiança e parceria.

Agradeço ainda pelo apoio, amizade constante e pelos aconselhamentos profissionais e pessoais de Murilo Jardelino, Rita Couto, Manoel Edson e Maurício Pedro.

Por fim, agradeço também aos amigos Paulo Martins, Luciane Freitas, Tainá de Sandes, Lia Altamir, Rogério Soares, Sílvia Carvalho e Demili Simeão pela força que me deram em alguns momentos mais difíceis dessa jornada de quase cinco anos. 
O que eu queria fazer parecia tão simples. Eu queria criar alguma coisa suficientemente viva e chocante para poder existir ao lado de uma manhã na vida de alguém. A mais comum das manhãs. Imagine, tentar uma coisa dessas. Que tolice. (Richard, personagem de As Horas, falando do que pretendia escrever em seu romance. Trad. Beth Vieira, 1999, p. 158) 


\section{RESUMO}

CARIBÉ, Y. J. A. Tradução, Adaptação e Reescrita da Obra de Virginia Woolf por Michael Cunningham em The Hours (1998). 2015. 170 f. Tese (Doutorado) Faculdade de Filosofia, Letras e Ciências Humanas, Universidade de São Paulo, São Paulo, 2015.

Esta tese propõe uma análise do romance americano The Hours (1998), de Michael Cunningham, que afirmamos ser uma reescrita da obra da escritora canônica Virginia Woolf na contemporaneidade. Trabalhamos com a ideia principal de adaptação, nos referindo de forma particular às adaptações literárias, tendo em vista que Cunningham utilizou para a composição de The Hours diversos trabalhos de fiç̧ão e não ficção que chamamos de 'obra' de Woolf, estando assim inserida no campo dos trabalhos acadêmicos relacionados aos Estudos da Tradução e da Adaptação. Por esse motivo, decidimos utilizar dois conceitos principais de adaptação para embasar esta discussão: o de Linda Hutcheon (2006) e o de Julie Sanders (2006), pesquisadoras que atuam nessas áreas. Embora o trabalho de Hutcheon seja mais direcionado às chamadas adaptações fílmicas, sua importante teorização em torno da adaptação e dos adaptadores foi amplamente utilizada dentro da discussão que propomos sobre Michael Cunningham e a problemática em torno da elaboração do romance em questão. Segundo Hutcheon (2006), a adaptação é vista como um processo que comporta tanto a repetição quanto a novidade, sendo os adaptadores responsáveis pela seleção dos textos adaptados e também pelo modo como esses textos serão configurados em um produto final. Também trabalhamos com os conceitos de adaptação e de apropriação de Sanders (2006). Esse último revela o aspecto autoral e ideológico dos adaptadores nas adaptações. As apropriações servem, segundo nossa conclusão, para mostrar a interferência direta do adaptador na narrativa, seus preceitos e propostas literárias. Também evidenciam sua interpretação particular de temas, argumentos e personagens do texto-fonte. Ainda nos valemos do conceito de reescrita de Lefevere (1992a) para caracterizar The Hours como o trabalho que retomou as discussões em torno da obra virginiana na contemporaneidade. Essa retomada se deu para dois públicos: os professional readers - conhecedores de seus textos de ficção e não ficção, as refrações - e também para os non-professional readers, novo público que não necessariamente teve contato com a obra dessa autora. Esta pesquisa examinou o segundo volume dos Diários (1980), o sexto volume das Cartas (1982), além do romance Mrs. Dalloway (1925), trabalhos de Woolf, para mostrar, através de alguns exemplos e comentários, como se deu o processo de adaptação e apropriação de temas, personagens e outros elementos desses textos. Também serviu para observar de que maneira o adaptador Cunningham alternou adaptações com apropriações para formar a narrativa The Hours, produto literário final. Esse romance reescreve a obra de Woolf no contexto atual porque dialoga principalmente com o conceito pertinente de apropriação, indispensável para a apreciação de formas narrativas que trabalham com a ideia de adaptação. O leitor contemporâneo busca na ideologia do escritor-adaptador seu entendimento particular e propostas atuais para esse diálogo.

Palavras-chave: adaptação; tradução; Michael Cunningham; reescrita; apropriação. 


\begin{abstract}
CARIBÉ, Y. J. A. Translation, adaptation and rewriting of Virginia Woolf's work by Michael Cunningham with the novel The Hours (1998). 2015. 170 f. Tese (Doutorado) - Faculdade de Filosofia, Letras e Ciências Humanas, Universidade de São Paulo, São Paulo, 2015.
\end{abstract}

This thesis proposes an analysis of the American novel The Hours (1998), by Michael Cunningham, which we claim to be a modern-day rewrite of the oeuvre of canonical writer Virginia Woolf. We worked with the main idea of adaptation, referring in particular to literary adaptations, considering that Cunningham used several works of fiction and nonfiction, which we call Woolf's "oeuvre", for the composition of The Hours. As such, it belongs to the field of academic work related to the Translation and the Adaptation studies. Therefore, we used two main concepts of adaptation to provide a basis for this discussion: those of Linda Hutcheon (2006) and Julie Sanders (2006), researchers working in these areas. Although Hutcheon's work is more directed toward so-called filmic adaptations, its important theorizing regarding adaptation and adapters was extensively used in the discussion that we put forward on the subject of adapter Michael Cunningham and the problems surrounding the creation of the novel The Hours. According to Hutcheon (2006), adaptation is considered to be a process that involves as much repetition as it does novelty, and adapters are responsible both for the selection of adapted texts and also for how these texts will be configured in a final product. We also worked with the concepts of adaptation and appropriation of Sanders (2006). The concept of appropriation reveals the authorial and ideological aspect of adapters in adaptations, the direct intervention of the adapter in the narrative, its precepts and literary proposition. Besides, it demonstrates the adapter's particular interpretation of themes, arguments and characters of the source text. We also availed ourselves of Lefevere's concept of rewriting (1992a) to characterize The Hours as the work that resumed the discussions surrounding Woolf's work in current times. This resumption was aimed at two readerships: professional readers - connoisseurs of her works of fiction and nonfiction, and the refractions - and also for non-professional readers - a new readership that has not necessarily had contact with Woolf's oeuvre. This research then examined the second volume of Diaries (1980), the sixth volume of Letters (1982), and the novel Mrs Dalloway (1925) - works by Woolf - to show, through examples and comments, how the process of adaptation of themes, characters and other elements of these texts played out. It was also necessary to observe how the adapter Cunningham alternated adaptations with his appropriations to create the narrative of The Hours, the final literary product. The novel The Hours rewrites Woolf's work in the current context because it principally maintains a dialog with the relevant concept of appropriation, indispensable to the enjoyment of narrative forms that work with the idea of adaptation. Present-day readers seek their own personal understanding and current propositions in the ideology of the writer-adapter for this dialog.

Key words: adaptation; translation; Michael Cunningham; rewriting; appropriation. 


\section{RESUMEN}

CARIBÉ, Y. J. A. Traducción, Adaptación y Reescritura de la Obra de Virginia Woolf por Michael Cunningham en The Hours (1998). 2015. 170 f. Tesis (Doctorado) - Facultad de Filosofía, Letras y Ciencias Humanas, Universidad de São Paulo, São Paulo, 2015.

Esta tesis propone analizar el romance americano The Hours (1998), de Michael Cunningham, el cual afirmamos es una reescritura de la obra contemporánea de la canónica escritora Virginia Woolf. Trabajamos con la idea principal de adaptación, haciendo hincapié en las literarias. Considerando que Cunningham utilizó diversos trabajos ficcionales y no ficcionales para la creación de The Hours éstos son llamados de "obra" de Woolf, ubicándose en el campo de las producciones académicas relacionadas a los Estudios de Traducción y de Adaptación. Utilizamos dos conceptos principales de adaptación para cimentar esta discusión: el de Linda Hutcheon (2006) y el de Julie Sanders (2006), quienes actúan en las áreas mencionadas. A pesar del trabajo de Hutcheon estar más direccionado a las adaptaciones fílmicas su teoría sobre adaptación y los adaptadores fue considerablemente utilizada dentro de la discusión que propusimos sobre la adaptación de Michael Cunningham y su problemática en torno a la producción del romance en cuestión. Según Hutcheon (2006) la adaptación es un proceso que permite la repetición y la novedad, y los adaptadores son responsables por la selección de los textos adaptados, así como de la forma en cómo éstos serán configurados. También trabajamos con los conceptos de adaptación y de apropiación de Sanders (2006). Este último revela el aspecto particular de los adaptadores. Las apropiaciones sirven, según nuestra visión, para mostrar la interferencia del adaptador en la narración, sus políticas y propuestas literarias. También evidencian su interpretación personal sobre los temas, argumentos y personajes del texto-fuente. Además, consideramos el concepto de reescritura de Lefevere (1992a) para caracterizar The Hours como el trabajo que retomó las discusiones de la obra virginiana en tiempos contemporáneos. Esto sobrevino para dos públicos: los "professional readers" - familiarizados con sus textos ficcionales y no ficcionales - y también para los "non-professional readers" - público joven que, no necesariamente, tuvo contacto con la obra de la autora. Esta investigación analizó, de los trabajos de Woolf, el segundo ejemplar de los Diarios (1980), el sexto de las Cartas (1982), además del romance Mrs. Dalloway (1925) para mostrar, a través de ejemplos y comentarios, cómo se realizó el proceso de adaptación de temas, personajes y demás elementos de esos textos. También sirvió para observar de qué forma Cunningham alternó adaptaciones con sus apropiaciones para crear la narración The Hours, producto literario. Este romance reescribe la obra de Woolf en el contexto actual, porque dialoga con el concepto de apropiación, indispensable para apreciar las narraciones que trabajan con el concepto de adaptación. El lector contemporáneo busca en la ideología del escritor-adaptador su comprensión personal y las propuestas para ese diálogo.

Palabras clave: adaptación; traducción, Michael Cunningham; reescritura; apropiación. 


\section{SUMÁRIO}

Introdução

Cap. 1 - Da Adaptação.................................................................... 26

1.1 Estudos da Tradução e Estudos da Adaptação................................ 26

1.2 Reescrita, Refração, Adaptação e Apropriação................................ 35

1.30 romance The Hours................................................................. 54

1.4 Michael Cunningham e a questão ética........................................... 59

Cap. 2 - Adaptações e apropriações em The Hours................................ 67

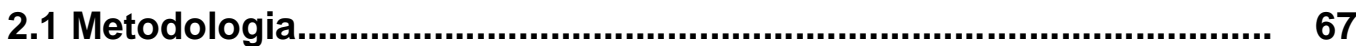

2.2 Das Cartas............................................................................. 69

2.3 Dos Diários................................................................................... 79

2.4 Suicídio, doença, Guerra e morte em The Hours.............................. 84

2.4.1 Suicídio, doença, Guerra e morte pelos Diários e Cartas............ 93

2.5 Insegurança e antipatia em The Hours............................................ 97

2.5.1 Insegurança e antipatia pelos Diários e Cartas......................... 99

2.6 Mrs. Dalloway em The Hours............................................ 104

2.7 Homossexualidade em The Hours, nos Diários e nas Cartas........... 126

Cap. 3 - A reescrita da obra de Virginia Woolf no Brasil........................ 131

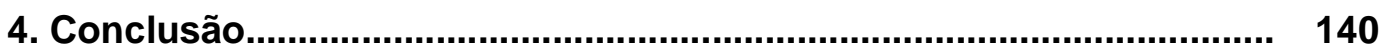

5. Referências bibliográficas................................................................. 156

Anexo 1 - Fotos de Virginia e Leonard Woolf......................................... 168

Anexo 2 - Capas de textos de Virginia Woolf....................................... 169

Anexo 3 - Cunningham e capas de The Hours (1998).......................... 170 


\section{LISTA DE TABELAS}

Tabela 1 - Publicações de Woolf no Brasil em 1946 e 1948 (1 ${ }^{\text {a }}$ fase)..... 134

Tabela 2 - Publicações de Woolf no Brasil de 1976 a 1993 (2ª fase)....... 136

Tabela 3 - Reedições de Woolf no Brasil de 1976 a 1993 (2 ${ }^{\mathrm{a}}$ fase).......... 136

Tabela 4 - Publicações de Woolf no Brasil após As Horas (3ª fase)....... 137

Tabela 5 - Publicações de Woolf após domínio público (2011) (4ª fase). 139 


\section{INTRODUÇÃO}

Sabemos que a história do gênero romance é permeada de discussões quanto às possibilidades de temas e estratégias narrativas que podem ser empregadas para caracterizá-lo dessa forma. São tantos os caminhos que se torna difícil classificar trabalhos tão diferentes dentro da mesma categoria romântica.

Na Inglaterra do século XVIII, por exemplo, o novel (romance inglês) surge querendo se diferenciar das narrativas clássicas tradicionais, segundo as pesquisas do especialista em romance inglês Michael Mckeon (1987). Ele acrescenta, em outro trabalho sobre o tema (MCKEON, 2000), que o novel continuou a modificar-se ao longo dos séculos, inclusive por fatores históricos e geográficos, como o período colonial e pós-colonialista em países como os Estados Unidos da América e em alguns países latinos. Esses fatores fizeram com que os romances escritos nesses lugares e épocas, e diante da situação de dominação política (colonialismo) que enfrentaram, tivessem características mais particulares ainda. Em princípio, entendemos que as particularidades dificultam uma unificação das teorias em torno do romance e indicam uma função que o gênero busca realizar: ser diferente, primar pela originalidade.

Descontente com essa constante atualização em formas e temas, Georg Lukács (2000), em outro importante estudo sobre o romance, chega a declarar - em tentativas sistemáticas de discussão - o fim desse gênero ou, pelo menos, sua crise, já entre 1914 e 1915 (data em que esse trabalho acadêmico foi escrito). O autor faz isso para falar do quanto o romance estava híbrido àquela época e do quanto havia se modificado desde seu surgimento, o que, de certa o forma, o teria descaracterizado. Para Lukács, grande parte dos romances mais conhecidos do 
início do século $X X$ já nem de longe se pareciam com os primeiros romances europeus. Eram narrativas importantes, porém não eram mais romances.

Passados três séculos percebemos que o gênero romance não desapareceu, demonstrando que críticos de literatura, acadêmicos e, principalmente, autores preferiram "discordar" de Lukács. Essas transformações demonstram a capacidade desse gênero literário de incorporar elementos que o atualizam. A partir do início do século XX, por exemplo, alguns autores ingleses chamados de modernistas reivindicaram essa atualização através de ensaios críticos e de seus próprios romances.

O Modernismo foi um movimento ocorrido na primeira metade do século $X X$ que influenciou manifestações culturais de toda ordem. Na literatura, o Modernismo inglês propôs um rompimento com formas e temas dos romances vitorianos e eduardianos. Esse movimento também teve versões (com características peculiares a cada país) nos Estados Unidos e no Brasil, as quais apresentaram como ponto em comum a reivindicação de mudanças nas produções artísticas e o distanciamento dos moldes mais tradicionais.

Um dos exemplos desse cenário foi a romancista, contista e ensaísta inglesa Virginia Woolf (1882-1941) que, em um ensaio crítico sobre o modernismo inglês (1921), chega a dizer que os escritores modernos deveriam centrar suas histórias no perfil psicológico das personagens, aspecto escolhido por ela para criticar os moldes tradicionalistas dos autores eduardianos. Woolf foi uma grande expoente da proposta modernista na Inglaterra, especialmente com os romances Mrs. Dalloway (1925) e Orlando (1928). Além de suas obras de ficção, Woolf expressou o que considerava moderno na literatura mundial em alguns de seus ensaios, inclusive 
usando sua própria literatura como exemplo. De acordo com ela, ousar, propor mudanças, especialmente usando técnicas narrativas e temas mais pertinentes àquele período cultural faziam parte do caminho a ser seguido (WOOLF, 1921). Isso reforçou ainda mais o caráter de diferenciação do modernismo inglês, juntamente com a publicação do romance Ulysses, de James Joyce (1922).

Essas atualizações do gênero refletiam as diversas mudanças na sociedade da época, processo "necessário" de renovação o qual foi apontado por Mckeon (2000) como tendo ocorrido novamente no final do século XX. Esse fato lembra a crise do romance, ocorridas entre 1914 e 1915 e identificada por Lukács (2000). Essa renovação ocorreu porque, segundo Mckeon (2000), as expectativas dos leitores estão cada vez mais diversas, impulsionando a ampliação das formas. Uma tentativa de atender a essa necessidade de renovação foi concretizada na literatura da atualidade através dos escritores do Pós-Modernismo.

O Pós-Modernismo é o movimento cultural do período recente, que vai dos anos 1940, com o fim da Segunda Guerra Mundial, até a atualidade (anos 2010). Nesse período, o preceito de busca pela novidade persiste, mas o movimento envereda também para questões mais filosóficas e reflexões da arte sobre a própria arte. Nesse sentido, incluímos uma tentativa de conceituar o Pós-Modernismo feita pelo filósofo e crítico literário britânico Terry Eagleton (1997 p. vii):

The word post-modernism generally refers to a form of comtemporary culture, whereas the term postmodernity alludes to a specific historical period. Postmodernity is a style of thought which is suspicious of classical notions of truth, reason, identity and objectivity, of the idea of universal progress or emancipation, of single frameworks, grand narratives or ultimate grounds of explanation. [...] Post-Modernism is a style of culture which reflects something of this epochal change, in a depthless, decentred, ungrounded, self-reflexive, playful, derivative, ecletic, pluralistic art which blurs the boundaries between 'high' and 'popular' culture, as well as between art and everyday experience. 
O teórico americano Brian McHale (1992, p. 247), especialista em pósmodernismo literário, vai além à medida que procura caracterizar as ideias dos escritores desse movimento. Baseado nas leituras de alguns romances da atualidade, que ele classificou como sendo pós-modernistas, ele compara o pensamento dos autores de literatura modernista com a concepção vanguardista daqueles que seguem o movimento do Pós-Modernismo. Conclui dizendo que os primeiros escreviam uma literatura orientada pela epistemologia em seus romances modernos e nas narrativas de ficção policial e, assim, preocupavam-se com questões como: o que podemos conhecer do mundo? Quem pode nos dizer isso? Essa informação é confiável? Já os autores pós-modernistas, orientados pela ontologia, preocupar-se-iam com questões como: o que é um mundo? Do que é feito? Há outros mundos além do nosso? Em que diferem?

Percebemos então que, segundo McHale, existe uma grande variedade de temas abordados nos textos do Pós-Modernismo. Nele, as possibilidades de criação incluem discussões de caráter filosófico sobre a ciência, sobre a linguagem etc. A pesquisadora da UNESP Giséle Fernandes (2009, p. 303) dialoga com essas tentativas de caracterização das obras literárias pós-modernistas por McHale (1992) em publicação sobre esse tema e conclui que "a diversidade de escolhas estéticas impede-nos de apresentar uma estética pós-moderna definitiva, pois as experimentações com a linguagem têm sido uma das características marcantes desse período".

Concluímos, então, que nem todos os romances da atualidade podem ser classificados como pós-modernos segundo as ideias propostas por McHale (1992), pois alguns seguem proposições do modernismo e de períodos anteriores. Porém, nos convencemos de que, no cenário recente da literatura, o romance 
contemporâneo é um gênero literário que se reinventa e que não tem um conjunto de traços ou ingredientes para defini-lo como tal. É hoje híbrido, o que destaca sua capacidade de autoironia e autocrítica e esse hibridismo assume várias formas na atualiade.

Na Inglaterra, lan Watt (1996), especialista em romance inglês, reforça as transformações a que o gênero narrativo foi submetido desde a publicação na Inglaterra de Pamela (1740), por Samuel Richardson, Robinson Crusoe (1719), por Daniel Defoe, e The History of Tom Jones, a founding (1749), por Henry Fielding até chegar à atualidade. Esses são considerados os primeiros novels da literatura inglesa. Podemos afirmar que, através dessas narrativas, Richardson, Defoe e Fielding criaram o gênero romântico na Inglaterra e exploraram suas potencialidades, revolucionando a literatura no mundo todo. A partir daí, escrever um romance tornou-se uma missão cada vez mais pautada nos preceitos da busca pela originalidade em temas e formas literárias. Um autor era mais reconhecido pela crítica literária quando mais novidade trouxesse à narrativa que criou.

Ocorre que tal angústia pelo novo pode ser visualizada em muitos romances pós-modernos. Ao mesmo tempo ousar também significa criar uma nova história "adaptando" elementos de narrativas anteriores, o que evoca o tema da intertextualidade. Fernandes (2009, p. 303) confirma esse pensamento ao dizer que "a intertextualidade é uma característica essencial do Pós-Modernismo, pois textos já produzidos surgem em outros textos, mas em um novo contexto".

A "adaptação" de elementos de trabalhos anteriores (ou textos-fonte) em romances da atualidade dialoga com o tema que Julia Kristeva (1980), em trabalho de referência, e também Graham Allen (2000), pesquisam como "intertextualidade". 
Percebemos, dessa forma, que esses conceitos (de adaptação e intertextualidade) se relacionam. Interessamos-nos de forma particular pelo trabalho de Allen (2000) sobre intertextualidade, pois ele estudou esse tema sob perspectivas diferentes: da Literatura Comparada, dos Estudos da Tradução, da Filosofia, da Semiótica e, mais recentemente, dos Estudos da Adaptação. Concluímos que sua preocupação é oferecer um panorama das áreas de pesquisa que dialogam com a ideia de "intertextualidade", ampliando esse conceito. Ele enfatiza a natureza "intertextual" de muitas narrativas do período recente (2000, p. 207), inclusive citando o romance The Hours, de autoria do escritor norte-americano Michael Cunningham (1998) e corpus desta pesquisa.

The Hours é um romance que carrega todo o hibridismo a que nos referimos antes: tem elementos adaptados de outras narrativas, mas que estão envoltos em um mote completamente novo e determinado pelo autor Cunningham. A pesquisadora inglesa Julie Sanders (2006) também se refere a The Hours (p. 115-9), quando discute as aproximações e distanciamentos entre os conceitos de "adaptação" e "apropriação", especialmente a adaptação e a apropriação literária. Uma "adaptação", segundo Sanders (2006), pode ser intralingual ou interlingual. Nesse caso, ela se refere àquelas narrativas publicadas em formato impresso ou digital que adaptam uma narrativa anterior ou apenas elementos de um texto-fonte, atribuindo ao autor desse texto-fonte e também ao profissional adaptador a responsabilidade pelo conteúdo daquela adaptação, definição muito semelhante à de intertextualidade por Kristeva (1980) e Allen (2000).

Pode ainda ser uma adaptação fílmica ou intersemiótica, como os filmes adaptados de romances. Sua ênfase nesse trabalho está nos romances que utilizam elementos adaptados e/ou apropriados de outros, como The Hours, e mesmo 
naqueles que foram classificados pelo mercado editorial como "adaptações". Sanders introduz ainda o conceito de "apropriação" para falar dos aspectos novos que são colocados pelo adaptador (sua ideologia) na obra adaptada e também daqueles reformulados por ele a partir dos textos-fonte. Esses dois conceitos, de "adaptação" e "apropriação", dialogam com a ideia de "intertextualidade" de Allen (2000).

A estratégia narrativa da "adaptação" é algo bastante antigo na história da literatura. Ela foi utilizada pelo escritor inglês Geoffrey Chaucer $^{1}$ ainda na Idade Média para a criação de um conto dos The Canterbury Tales. Chaucer adaptou elementos da narrativa /I Teseida, de Bocaccio, ${ }^{2}$ para escrever o conto The Knights's Tale (SIMPSON; DAVID, 2007, p. 215), tendo seu trabalho reconhecido até hoje como uma das obras mais importantes da literatura inglesa.

Verificamos que "adaptar" formas diversas nos romances do século XXI é também algo muito frequente e que nos chama a atenção, visto que próprio romance - um gênero literário complexo - teve em suas primeiras versões outros gêneros literários mais simples em sua composição, como a carta, o diário e o livro de viagens (WELLEK e WARREN, 1962, p. 299). Exemplo disso é o romance Pamela (1740), de Samuel Richardson, um romance epistolar. Assim, percebemos na atualidade da literatura mundial inclusive um retorno a essas formas narrativas da gênese do romance, como a carta e o diário. Temos uma parcela de autores dos anos 1980 até os anos 2010 que publicaram romances epistolares, além daqueles

\footnotetext{
${ }^{1}$ Chaucer viveu entre 1343 e 1400 . Dentre seus trabalhos mais reconhecidos podemos citar como exemplo The Canterbury Tales, publicado em 1475.

${ }^{2}$ Giovanni Boccaccio foi um escritor italiano que viveu de 1313 a 1375 e publicou, dentre outras obras, o romance clássico Decameron (publicado entre 1349 e 1352).
} 
romances de ficção que mesclam diários e cartas não ficcionais à sua forma narrativa, como The Hours (1998).

The Hours é, portanto, uma narrativa pós-moderna com diversas intertextualidades. É um romance que "adaptou" elementos anteriores em um novo contexto, o que prova que, de forma mais específica, o romance americano também se transformou ao longo dos séculos (se compararmos a proposta narrativa de The Hours a qualquer romance americano do século XIX, por exemplo). A citação de Malcom Bradbury (1991, p. 197), em estudo ${ }^{3}$ sobre o romance americano na atualidade, confirma esse preceito:

\begin{abstract}
Em seus melhores momentos, o romance ${ }^{4}$ não é apenas um tipo infinitamente repetível, um corpo de estilos e modos de expressão habituais e, portanto, aparentemente inocentes, um conjunto de subgêneros fixos e abertos a modernizações locais por autores recentes; ele é um ato de apreensão eternamente cambiante, pertencente ao mundo de nossos pensamentos cambiantes, nossa história cambiante, nossos meios cambiantes de dar nome à experiência, e não pode permanecer parado.
\end{abstract}

Finalmente, podemos dizer que o romance foi assimilado por autores recentes como um gênero literário narrativo infinitamente repetível e aberto a modernizações locais, para que possa congregar na atualidade ineditismo e também elementos adaptados de textos-fonte e assim ser reconhecido pelo público e pela crítica, especialmente através das apropriações dos autores contemporâneos. Esse gênero, portanto, já comporta em si essa possibilidade de mudança, não sendo preciso criar outro. Abre-se, assim, uma possibilidade para discutir uma noção mais flexível sobre gêneros (literários).

\footnotetext{
${ }^{3}$ Em tradução publicada pela editora Jorge Zahar.

${ }^{4}$ Nesse caso o romance americano do período recente, como The Hours.
} 
Ocorre, porém, que romances pós-modernos como The Hours também incluem elementos inéditos e que não podem ser ignorados. Esses elementos é que constroem uma história que, embora repleta de adaptações, revela-se importante como produto literário final e capta a atenção do público. The Hours (CUNNINGHAM, 1998) cita frases, personagens ou situações que remetem o leitor a outros trabalhos já existentes, mas não é classificado pela editora que o publicou como uma "adaptação literária" porque não é. Veremos adiante que o conceito de apropriação parece mais pertinente quando falamos de The Hours.

Nesta pesquisa vamos apontar momentos em que a narrativa The Hours adaptou elementos de textos-fonte virginianos, dialogando com os conceitos de adaptação e/ou apropriação. Dentre as adaptações que citaremos, cabe ressaltar que não vam os discutir se é mais ou menos distante de um texto primeiro, ou mais "fiel", conforme ocorria durante o longo período de trabalhos acadêmicos publicados sob o viés das teorias linguísticas, o que ocorreu aproximadamente até 1990 (Edwin GENTZLER, 2001).

É fato que o autor Michael Cunningham "adapta" diversos elementos do romance de Woolf intitulado Mrs. Dalloway (WOOLF, 1925), bem como de alguns textos de não ficção, como o segundo volume de The Diary of Virginia Woolf (1980) e o sexto de The Letters of Virginia Woolf (1982), conforme menção na ficha catalográfica dessa narrativa. $\mathrm{O}$ autor utiliza ainda ${ }^{5}$ um ensaio de Virginia Woolf (2000), Mrs. Bennet and Mrs. Brown, na criação de uma de suas personagens (Laura Brown), conforme julga Sanders (2006, p. 116), além de depoimentos e biografias diversas.

\footnotetext{
${ }^{5}$ Cunningham declara em "a note on sources" que pesquisou outras fontes. Entretanto, optamos por trabalhar apenas com aquelas citadas na ficha catalográfica.
} 
Também inclui novas discussões em The Hours através de temas de sua preferência, o que Sanders chama de "apropriação". Entendemos que esse fator é que leva romances como esse a serem reconhecidos mundialmente, pois isso mostra o potencial do autor em reproduzir elementos de outros textos em meio aos seus, configurando uma narrativa de formato inédito. O trabalho de apropriação é, portanto, fundamental na literatura mundial e compõe o formato de muitas adaptações.

Entendemos que houve, com o lançamento de The Hours, uma tentativa de retomar a leitura de Virginia Woolf pelo mundo na atualidade (hipótese), apostando em uma possível receptividade do público leitor. Não queremos dizer com isso que o lançamento desse romance pareceu proposital ou encomendado, apenas deduzimos que a data de publicação foi muito feliz no sentido de aproximar leitores interessados e obras em momento oportuno. A proposta de Cunningham, segundo esta tese, foi "reescrever", segundo conceito do pesquisador belga dos Estudos da Tradução André Lefevere (1992a), a "obra" da escritora inglesa, que inclui os textos-fonte de ficção e não ficção citados. Dessa forma, alguns eventos também contribuíram para consolidar essa "reescrita" da obra woolfiana pelo mundo na atualidade iniciada pelo romance The Hours: a repercussão em torno da publicação desse romance; os prêmios literários direcionados a esse trabalho; as reportagens e a crítica literária eminentemente favorável; a rápida tradução e publicação para diversas línguas - no Brasil, seu lançamento ocorreu já no ano seguinte (1999); o relançamento dos romances e contos de Woolf na Inglaterra e nos Estados Unidos e suas subsequentes traduções em vários países; o lançamento em 2002 de um filme homônimo baseado no livro; a repercussão em torno do filme; e, finalmente, o prêmio de melhor atriz recebido na cerimônia do Oscar de 2003 por Nicole Kidman 
por sua atuação como Virginia Woolf. Tudo isso pode ser visto como um convite à leitura de textos de Woolf, autora que ocupa posição importante dentro dos sistemas literários mundiais (Itamar EVEN-ZOHAR, 2000).

Começamos então a investigar o processo de composição e publicação de The Hours. Descobrimos que, segundo o pesquisador John Milton (2001), pesquisas recentes - dos Estudos de Tradução - têm se voltado nos últimos anos à análise dos aspectos históricos que envolvem a publicação de narrativas literárias na atualidade. Esses trabalhos nos informam que é a conjunção com fatores políticos e mercadológicos que possibilita a publicação de determinados romances traduzidos. Podemos inferir que as "adaptações" literárias também são publicadas de acordo com esses fatores. Tratamos aqui da iniciativa de determinados agentes de publicar textos que resgatam outros, como foi o caso de The Hours, pautando-se em objetivos editoriais pré-estabelecidos. A partir daí, são essas conjunções políticas e mercadológicas citadas que sugerem aos novos autores como Cunningham quem, o quê e que período "adaptar" em seus romances.

Destacamos então um elemento bastante pesquisado nos Estudos da Tradução e também nos Estudos da Adaptação: a do "adaptador", aquele que retextualiza e que, portanto, "traduz", fazendo releituras de textos de natureza interlingual clássica, ou intralingual, ou adaptando um determinado texto para uma nova mídia, dentre tantas situações. É importante dizer que entedemos como "adaptadores" todos aqueles que retrabalham um texto-fonte em um novo texto, tais como alguns escritores de romances modernos (classificados ou não pelas editoras como adaptações), tradutores, roteiristas, biógrafos, críticos, editores e diretores de cinema, etc. Sendo assim, entendemos que até mesmo os tradutores podem ser chamados de "adaptadores" nesse contexto. 
Observando The Hours, inferimos dizer que esse trata-se de um trabalho que conseguiu, conforme veremos a seguir, estabelecer uma comunicação com leitores e espectadores contemporâneos sob a ótica woolfiana. Esse fato justifica a nossa principal proposta: a realização de um estudo sobre como elementos de alguns textos-fonte de Woolf foram "adaptados" nesse novo romance.

Esta tese está estruturada em três capítulos: no primeiro, situamos a proposta dentro dos Estudos da Tradução e da Adaptação. Nesse contexto, começamos com o viés da Linguística, evidenciado pelo trabalho pioneiro do linguista russo Roman Jakobson (1959) e os conceitos de tradução "intralingual", "interlingual" e "intersemiótica", relacionando-os à ideia de "adaptação". Nesse mesmo capítulo, discutimos alguns conceitos importantes do campo dos Estudos da Tradução e da Adaptação, como os de "refração" e "reescrita", de André Lefevere (1982a, 1982b, 1992a e 1992b), "adaptação" e "apropriação”, de Julie Sanders (2006).

Também utilizamos o conceito de "adaptação" da pesquisadora canadense Linda Hutcheon (2006) para problematizar a questão de Michael Cunningham como autor/adaptador. Apresentamos ainda uma pesquisa de caráter descritivo sobre o romance The Hours e seu autor/adaptador. Tentamos também entender questões de "visibilidade" dos tradutores e do autor/adaptador Cunningham através do trabalho do tradutor e teórico da tradução Laurence Venuti (2004). Como último item dessa parte, trabalhamos o aspecto ético que permeia as discussões envolvendo narrativas que "adaptaram" elementos de outros trabalhos ou se "apropriaram" (SANDERS, 2006) de elementos deles, como The Hours.

No segundo capítulo, apresentamos o discurso woolfiano pela voz dos personagens de Cunningham. Tentamos, assim, sob a abordagem dos Estudos da 
Tradução e da Adaptação, oferecer um exame acerca do processo de "reescrita" de Mrs. Dalloway (WOOLF, 1925), do segundo volume dos Diários (1980) e do terceiro volume das Cartas (1982) em The Hours. Utilizamos exemplos de trechos desses textos-fonte de Woolf para mostrar de que forma foram adaptados ou apropriados por Cunningham.

Em seguida, no último capítulo, trabalhamos a "reescrita" da "obra" de Virginia Woolf no Brasil. Essa parte discute o impacto do lançamento de As Horas (Companhia das Letras, 1999), traduzido por Beth Vieira, e do filme homônimo (2002) para a consolidação do processo de reescrita dessa escritora inglesa no nosso país. O mesmo capítulo cita ainda reportagens publicadas em jornais brasileiros e estrangeiros relacionadas aos autores Woolf e Cunningham. Também citamos a fala de alguns tradutores de romances woolfianos no Brasil com o intuito de discutir a experiência de "reescrever" (LEFEVERE, 1992a) Woolf. Esperamos, portanto, apresentar conclusões inovadoras diretamente voltadas para os Estudos da Tradução e Estudos da Adaptação.

Com relação à metodologia desta tese, trabalhamos com a pesquisa bibliográfica, através do método analítico-descritivo e do estudo de caso (MARCONI e LAKATOS, 2007), discutindo textos acadêmicos sob a forma de livros, artigos, teses e dissertações das áreas de Literatura Comparada, Estudos da Tradução e Estudos da Adaptação. Também consultamos textos jornalísticos e biográficos relacionados à Cunningham e Woolf, bem como websites relacionados à tradução desses autores, como o de Denise Bottmann (2013). Como nossa bibliografia acadêmica preferencial para consulta e citações é formada em sua maioria por autores estrangeiros (e que, portanto, publicaram seus trabalhos em língua inglesa), optamos por não traduzir as citações diretas. Adotamos o mesmo procedimento para 
os exemplos de trechos dos diários e cartas de Woolf apresentados no segundo capítulo, todos inéditos em língua portuguesa.

O corpus desta pesquisa é composto basicamente pelo romance The Hours (1998), de Michael Cunningham. Inclui ainda os textos especificados de forma direta em The Hours (1998): The Diary of Virginia Woolf vol. 2 (1980), The Letters of Virginia Woolf vol. VI (1982) e Mrs. Dalloway (1925). Assim, observamos as estratégias narrativas desenvolvidas pelo autor para reconfigurar personagens, enredo e situações primeiramente apresentadas por Virginia Woolf nesses textos.

Considerando-se que o romance The Hours (1998) como sendo uma "reescrita" ou uma "tradução" da "obra" de Woolf recodificada por Cunningham, a comparação dos textos-fonte com The Hours (1998) poderá fornecer ao analista um campo rico de estudos em novas possibilidades de leitura e interpretação de textos de ficção e não ficção da escritora inglesa. Acredita-se que esta tese seja relevante para o avanço das pesquisas relacionadas às seguintes áreas: os Estudos Linguísticos e Literários em Língua Inglesa, Estudos da Tradução e Estudos da Adaptação. Vale ressaltar que pesquisas voltadas para o tema da "adaptação" trazem uma pauta, neste momento, bastante explorada dentro de importantes grupos de pesquisa, congressos e simpósios nacionais e internacionais das áreas citadas. 


\section{CAPÍTULO 1 - DA ADAPTAÇÃO}

\subsection{Estudos da Tradução e Estudos da Adaptação}

Percebemos que o mercado editorial da atualidade aponta para uma tendência adaptativa em muitas das narrativas publicadas. Nisso, incluímos as traduções intra e a interlinguística de clássicos da literatura mundial a fim de trazêlos para mais perto de outros públicos. Esses termos, criados por Roman Jakobson em sua obra On linguistic Aspects of Translation (1959), são definidos da seguinte forma: tradução intralingual é a releitura de um romance feita por outro autor, reconfigurado-o em um novo texto (porém no mesmo idioma); tradução interlingual é o conceito mais comumente associado ao trabalho de passagem de textos-fontes para outras línguas, refletindo, de acordo com o autor, "a tradução em si".

Jackobson refere-se ainda na mesma obra às traduções intersemióticas, que incluem, por exemplo, os filmes traduzidos de romances. Sendo assim, embora valorizando o conceito de tradução interlingual, ele termina por ampliar o conceito de tradução nos anos 1960 ao considerar filmes baseados em livros já publicados como um de seus exemplos. Esses conceitos foram acolhidos nos Estudos da Tradução, tendo em suas bases a Linguística e Semiótica. Assim, estudar um romance em inglês que foi traduzido intralingualmente, porém em linguagem mais simples que a do texto-fonte, passou também a ser um objeto dessa área de estudo (Susan BASSNETT, 2002), embora a questão não seja apenas a da simplificação da linguagem. Foi também a partir de Jakobson que os pesquisadores desse campo puderam analisar filmes elaborados a partir de romances e chamá-los de traduções (intersemióticas) desses romances, passando também a fazer parte de pesquisas dentro dos Estudos da Tradução. 
Em épocas mais recentes, a ideia de tradução intersemiótica de Jakobson passou a ser chamada de adaptação (fílmica). Esse termo também é usado no mercado editorial do mundo todo para falar das traduções intralinguais ou interlinguais em que houve intervenção direta de um adaptador. Dessa forma, percebemos as adaptações literárias e fílmicas como objetos de estudos de grande interesse na atualidade.

Assim, nos propomos inicialmente a apresentar o conceito-chave que permeará toda esta tese: o de "adaptação". Referimo-nos particularmente a narrativas que são assim classificadas pelas editoras, provocando o reconhecimento imediato de um texto-fonte e de seu autor por um determinado público (AMORIM, 2005). Também falaremos de trabalhos que, como The Hours, de Michael Cunningham, configuram um texto novo, tendo embora adaptado elementos de um texto-fonte.

O emprego do termo adaptação ocorreu concomitantemente a um considerável aumento na quantidade de pesquisas relacionadas a adaptações verificado nos últimos vinte anos. Para atender a essa demanda, foi criada em 2008 pela Oxford University Press (ALLEN, 2000, p. 204) a revista acadêmica Adaptation, periódico de importância internacional destinado exclusivamente a publicações de trabalhos que tinham como objeto de estudo uma adaptação. O ano de 2008 marca, assim, o nascimento dos Adaptation Studies (Estudos da Adaptação), umam área de pesquisa dedicada somente a adaptações de todos os tipos, especialmente às fílmicas. Atualmente, destaca-se também a publicação do periódico acadêmico de referência internacional Journal of Adaptation in Film and Performance. 
John Milton (2010), em artigo sobre o tema, dá exemplos de outros tipos da adaptação, como a tradução de clássicos da literatura tanto para crianças como para o grande público, a tradução de canções etc. Esses são exemplos de obras que podem ser consideradas adaptações ou que incluem processos de adaptação. Milton lembra ainda que as adaptações em um determinado trabalho vão depender do público, de sua idade, classe social e possíveis deficiências físicas, como no caso das audiodescrições, filmes em que a imagem é narrada em áudio para espectadores cegos.

Um caso que nos chama a atenção é também relatado por Milton em trabalho importante sobre sua experiência de tradutor no "Clube do Livro" (MILTON, 2001). autor descreve que nessa época ele tinha que traduzir interlingualmente, junto com uma equipe, clássicos da literatura inglesa e norte-americana para um público de massa e que seriam categorizados como traduções. Contudo, precisava com frequência condensar os textos (diminuí-los), retirar palavras e frases de ordem política, religiosa, sexual etc., o que acabava caracterizarindo o trabalho como uma adaptação. Esses procedimentos realizados por Milton revelam, então, que adaptar é intervir diretamente na linguagem dos textos segundo acordos pré-estabelecidos.

Ressaltamos que as pesquisas relacionadas às adaptações fílmicas representam grande parte dos trabalhos acadêmicos sobre adaptação. Esses trabalhos são com frequência baseados nos estudos internacionais de Mireia Aragay (2006), da dupla Debora Cartmell e Imelda Wheleham (1999), Seymour Chatman (1980) e de Robert Stam (2004), que tratam da relação entre literatura e cinema, levando em conta inclusive as teorias do cinema para analisar a passagem de um texto (signo verbal escrito) para outros signos ou meios. 
A pesquisadora canadense Linda Hutcheon (2006), com foco nas adaptações fílmicas, consolida a fundação dos Estudos da Adaptação ao tentar elaborar uma teoria exclusiva desse campo de estudos. O resultado desse trabalho é a publicação em 2006 de Theory of Adaptation. Caminho semelhante ao de Hutcheon é tomado por Laurence Venuti em artigo sobre o tema da adaptação (VENUTI, 2007) em que o autor chega a sugerir uma nova metodologia para a discussão de filmes adaptados de romances, com o viés dos Estudos da Tradução. Tratando como equivalentes os conceitos de tradução e adaptação, Venuti critica o modelo atual de pesquisa sobre filmes adaptados, adotado por pesquisadores como Robert Stam (2004), e sugere uma nova forma, baseada no que ele chama de modelo comunicativo.

A crítica feita por Venuti tem como base a ideia de que existem muitas possibilidades de análise das adaptações, quase todas partindo de uma abordagem hermenêutica. Ele sugere então, que, para se realizar um estudo sob a abordagem dos Estudos da Tradução (BASSNETT, 2002), é preciso que se dê mais atenção ao interpretante do tradutor, conceito trabalhado na Semiótica e na Linguística, que nesse caso faz referência às ideias que o tradutor tem do romance (texto-fonte) em sua mente e o que espera encontrar na adaptação.

Essa sugestão para que se aplique uma metodologia mais definida para a análise de filmes "traduzidos" ou adaptados a partir de romances (a serem analisados sob a ótica dos Estudos da Tradução) dialoga com a proposta do pesquisador Gilden Toury (1995). Ele sugere que os tradutores operam sob alguns regimentos, mesmo inconscientemente. Venuti quer, portanto, mostrar que há um modelo mais adequado dentro da área dos Estudos da Tradução para analisar filmes e de acordo com os preceitos desse campo. Ele dá diversos exemplos sobre como deveria ser essa análise e conclui seu pensamento dizendo que as pesquisas 
seguintes à sua deveriam seguir esses padrões. Só assim, segundo ele, trabalhos sobre adaptações acrescentarão ao campo de estudos das teorias de tradução (VENUTI, 2007).

Nacionalmente, também existem diversos trabalhos que tratam dessa passagem de uma obra literária para o formato audiovisual, como é o caso do livro da professora brasileira Thaís Diniz, Literatura e cinema (1999). Há ainda um grande número de artigos publicados ora usando o termo tradução intersemiótica, ora adaptação. Há, por fim, teses e dissertações acadêmicas que aqueceram as relações entre literatura e cinema no Brasil sob o ponto de vista dos Estudos da Tradução e da Adaptação. A tese de doutorado de Carlos Silva (2007), por exemplo, analisa a passagem da personagem Clarissa Dalloway do romance Mrs. Dalloway (WOOLF, 1925) de Virginia Woolf primeiro para o filme homônimo (1997), depois para The Hours (1998 e 2002).

O termo adaptação, agora pensando nas adaptações literárias, evoca questões que envolvem resumo, resenha crítica, ponto de vista, escolha das palavras, destino dos personagens, discurso e etc, tudo isso envolvendo o nome de um autor (geralmente canônico) de um texto-fonte e também o nome de um adaptador. Na discussão acadêmica brasileira relacionada à tradução literária, esse termo (adaptação) era há alguns anos citado apenas como um procedimento técnico de tradução, como fez Heloísa Gonçalves Barbosa (1990) em seu estudo a partir da obra dos linguistas franceses Jean Vinay e Paul Darbelnet (1977), o que mostra certa relação entre os conceitos de tradução e adaptação.

No Brasil, há também a pesquisa de Lauro Amorim (2005) que tenta esclarecer as relações entre os conceitos de tradução e adaptação, tratados como 
equivalentes por Venuti (2007). Amorim explica que a ideia de adaptar é comumente confundida com simplificar. Isso ocorre porque o mercado editorial atribui o "selo" de adaptação apenas para obras em que, segundo esse mercado, houve interferência direta de um adaptador, especialmente na linguagem.

Nas adaptações, segundo Amorim (2005), há uma liberdade maior de composição do que a que seria permitida a um tradutor e isso provoca inclusive discussões sobre autoria, pois tanto adaptador como autor do texto-fonte aparecerão na obra adaptada ocupando posições semelhantes. Por isso, para muitos autores da atualidade, ter sua obra publicada enquanto adaptação a desqualificaria. Amorim mostra ainda que adaptações acontecem também nos textos que os editores publicam como traduções (interlinguais), e uma tradução deveria indicar um texto mais fiel ou mais próximo ao texto-fonte, o que nem sempre acontece. Nesse sentido, os critérios de classificação das editoras são no mínimo frágeis e contraditórios.

Amorim também aponta as fragilidades entre esses dois conceitos (tradução e adaptação) dando exemplos de traduções que, em determinado momento, adaptaram elementos. Opta, então, por não assumir distinções entre os termos e conclui sugerindo que, no âmbito da atualidade, o conceito de tradução seja ampliado para além do pensamento tradicional. Lembra ainda que, especialmente na tradução interlinguística de literatura estrangeira, a adaptação é um processo muito utilizado.

Diante das semelhanças verificadas por Amorim (2005) optamos nesta pesquisa por também não fazer distinção entre os conceitos de tradução e adaptação. Dessa forma, um filme adaptado de um romance é também uma 
tradução desse filme e, do mesmo modo, um romance como The Hours se constituiria na tradução da "obra" da escritora inglesa Virginia Woolf num sentido mais amplo, como será descrito a seguir. Portanto, poderíamos empregar o termo adaptação nos mesmos casos. Os dois conceitos serão reconhecidos no contexto deste trabalho como equivalentes, embora seus papeis sejam comumente encarados como diferentes pelo público. Como forma de atualização deste trabalho, preferimos o termo mais recente, qual seja adaptação. Assim, tendo em vista as incoerências do mercado editorial na classificação de trabalhos como "tradução" (quando na verdade são adaptações), e ainda pela forte presença dos elementos de trabalhos de Woolf adaptados por Cunningham nessa construção, poderemos, ao longo desta tese, nos referir a esse romance como uma adaptação (embora percebendo muito mais as apropriações que adaptações).

Internacionalmente, outros pesquisadores que publicaram trabalhos clássicos dos Estudos da Tradução, como Gerardo Vásquez-Ayora (1977) e Peter Newmark (1988), também se referiram à palavra adaptação como sendo um passo, uma técnica aplicada exclusivamente na tradução de textos interlinguais. Quando se referem ao termo adaptação, esses pesquisadores falam apenas em trocar situações citadas em textos fonte que inexistem na realidade do público do texto traduzido. Isso acontece porque essas situações são típicas e não farão o menor sentido para o público de chegada.

Umberto Eco, escritor e semioticista da atualidade, também dedica um tópico de seu trabalho teórico sobre tradução, Quase a mesma coisa (2007), para falar das adaptações. Ele relata ao longo desse texto alguns de seus preceitos sobre tradução, ao mesmo tempo que comenta traduções de trechos de seus romances para outras línguas. Eco apenas se refere brevemente ao termo adaptação para 
falar do caso das traduções intersemióticas, ou àqueles filmes adaptados a partir de romances, por exemplo.

Podemos concluir a partir dessas leituras e também de nossa experiência enquanto tradutor e professor de tradução literária que sempre ocorrem situações em que o tradutor adapta de alguma forma um texto ao traduzi-lo intralingualmente, interlingualmente ou intersemioticamente. O tradutor é, portanto, um adaptador, ou seja, aquele que retextualiza e que "traduz" o texto-fonte, fazendo releituras de natureza interlingual ou intralingual, ou adaptando um determinado texto para uma nova mídia, dentre tantas situações. Além dos autores recentes que, como Michael Cunningham, adaptaram textos-fonte em uma nova proposta, também chamamos de adaptadores os tradutores, roteiristas, biógrafos, críticos, editores e diretores de cinema, etc, reafirmando que também os tradutores serão chamados de adaptadores no contexto desta tese (HUTCHEON, 2006).

No caso das adaptações literárias formais - aquelas que foram assim classificadas pelas editoras -, destaca-se o nome do autor do texto-fonte, o título do texto-fonte e, muitas vezes, o nome do adaptador. Se encararmos os adaptadores como "tradutores", veremos que essa dinâmica editorial, exclusiva das adaptações, reforça a proposta de Venuti (2004). Esse autor sugere uma maior visibilidade aos tradutores nas obras literárias traduzidas interligualmente, através de, por exemplo, sua identificação na capa dos livros, algo que raramente ocorre. Em um romance clássico ou em um conto adaptado para outras linguagens (ou mesmo para outras 
línguas), os adaptadores costumam figurar na capa dos trabalhos com expressões da língua portuguesa como "recontado por", "contado por", "adaptador por", 6 etc.

O adaptador, sem dúvida, é muito mais valorizado editorialmente em uma adaptação literária que os tradutores interlinguais em uma tradução. Mas veja como funciona essa relação de tradutor, novo autor (como Cunningham) e autor canônico no mercado editorial: muitas vezes o tradutor ou o adaptador é citado em um romance da capa ao material de divulgação. Isso ocorre porque ele geralmente é também um escritor representativo naquele contexto de publicações, trazido pela editora para dar credibilidade à edição. O autor do texto-fonte será reconhecido em determinado país de chegada via tradutor/adaptador. Da mesma forma, esse tradutor / adaptador ganha fama diante da relação com o texto de um escritor coanônico.

Podemos citar dois exemplos disso no Brasil, ambos com traduções pioneiras de Virginia Woolf: Mário Quintana (autor da tradução de Mrs. Dalloway, em 1946, reeditada em 1980) e Cecília Meireles ${ }^{8}$ (autora da tradução de Orlando, em 1948, reeditada em 1978). Nos anos 1940, ao promover o lançamento dos primeiros trabalhos de Woolf no Brasil, verificamos que os nomes desses escritores/tradutores tiveram fundamental importância, visto que já eram reconhecidos por diversos públicos leitores do nosso país. O mesmo não podia ser afirmado sobre Virginia Woolf, autora relativamente desconhecida no Brasil, e que dependeu da atuação de ambos como "apresentadores" para um público mais amplo de sua literatura para passar a ser lida nesse país.

\footnotetext{
${ }^{6}$ Os termos citados são equivalentes em tradução aos utilizados em edições norte-americanas e inglesas a ver: told by, adapted by, retold by ou interpreted by.

7 Mário Quintana (1906-1994), escritor gaúcho, é também autor também de vários trabalhos de tradução.

${ }^{8}$ Cecília Meireles (1901-1964), reconhecida poeta carioca, foi também autora de traduções literárias.
} 
Dizemos, então, que a publicação de adaptações literárias promove uma revalorização de autores mais antigos para públicos ambientados aos cânones e também uma apresentação desses autores aos que os desconhecem, algo que muitas editoras consideram como importante e lucrativo. Para os primeiros leitores, as adaptações funcionam como uma forma de resgate dos textos-fonte ou uma tentativa de rememorá-los. No caso do Brasil utilizar escritores conhecidos para fazer a tradução desses cânones seria uma forma de assegurar mais ainda essa recepção. Tratamos aqui de um nicho do mercado editorial mundial: trabalhar com enredo, personagens e outros elementos adaptados de narrativas anteriores já bem conhecidas e aclamadas pela crítica, porém em linguagem e cenários modernos, como fez Cunningham ao compor o romance The Hours.

\subsection{Rescrita, Refração, Adaptação e Apropriação}

Analisar o processo de composição de uma narrativa elaborada a partir de alguns textos-fonte como The Hours nos remete inicialmente aos importantes conceitos de "refração" (1982a e 1982b) e" reescrita" (1992a e 1992b), de André Lefevere. Esses conceitos, amplamente utilizados em trabalhos acadêmicos dos Estudos da Tradução (BASSNETT, 2002) da atualidade, fazem parte do grupo dos estudos descritivistas da Tradução (Gilden TOURY, 1995).

Embora em seus escritos Lefevere se refira de forma mais direta às traduções interlinguais como textos que refratam (e também reescrevem) textos anteriores na literatura, podemos afirmar que o conceito da "refração" também inclui os chamados textos adaptados para um novo público/meio. Ele cita como exemplo de refrações as traduções, resenhas críticas de textos, os resumos, historiografias, antologias e tudo mais que evoque um texto-fonte de alguma forma (1982a), levando em consideração 
também o sistema de onde provém esse texto e o sistema (diferente) para o qual será publicado (EVEN-ZOHAR, 2000), medidas que também são tomadas quando se publica uma adaptação.

O conceito de refração de Lefevere antecede o de reescrita em alguns anos, o que nos mostra que esse pesquisador persistiu nessa ideia e procurou desenvolvê-la mais ainda. Atualmente a maior parte dos trabalhos acadêmicos prefere trabalhar somente com o conceito mais recente, o de reescrita. Ainda assim, acreditamos ser importante colocar nossas impressões sobre as refrações de Lefevere.

As "refrações" chamadas de comuns cumprem na verdade diversos papéis. Elas podem funcionar como um meio de trazer de volta trabalhos anteriores, direcionados por uma determinada ideologia, porém sem um caráter mais profissional ou especializado. Também introduzem trabalhos de literatura de sua própria cultura para leitores que os desconhecem, como um verbete, uma resenha ou um resumo descompromissado. Alguns adaptadores literários, por exemplo, refratam clássicos da literatura mundial para crianças. Nas refrações comuns a linguagem simples "refrata" (reflete) o texto fonte. É como se Lefevere dissesse que os leitores comuns devem enxergar os textos-fontes através dessas refrações. Os tradutores literários refratam textos estrangeiros para um público diferente daquele em que o texto-fonte foi publicado. Enfim, são muitas as possibilidades de refração. A intenção é apenas descrever o texto-fonte de formas diversas, não de julgá-lo, por isso chamamos essas refrações de comuns.

Por outro lado, temos também as refrações em resposta aos trabalhos literários lançados no mercado editorial. Assim, se hoje lançamos um romance, 
teremos uma série de refrações promovidas principalmente pela academia (crítica literária) e pelo jornalismo especializado para apoiá-lo ou criticá-lo. Em estudo posterior (1982b), Lefevere classifica chama essas refrações de "refrações críticas": são as introduções, notas de rodapé, resenhas e artigos feitas por especialistas, com juízo de valor, notas, recomendação ou reprovação. Dessa forma, apenas as refrações especializadas são "críticas". Os jornais mais importantes de cada país costumam publicar resenhas dos lançamentos de importantes romances nacionais e também das traduções ou reedições publicadas. Esses textos são fundamentais para promover uma maior visibilidade e compreensão desse trabalho editorial. A academia e o jornalismo, então, publicam refrações críticas sobre determinada obra com vistas a difundi-la, explicá-la e até rechaçá-la.

Contudo, o intuito principal da resenha (tipo de refração crítica) é apresentar o texto, funcionando como um convite à sua leitura. Lefevere (1982b, p. 18) confirma esse preceito ao dizer que as refrações críticas são responsáveis diretamente pela difusão de trabalhos de literatura para públicos que não estão interessados ou motivados o suficiente para chegarem aos textos-fonte, que ele chama de nonprofessional readers (1992b). Para caracterizar esse grupo de leitores, basta dizer que muitos deles lêem apenas refrações críticas relacionadas à obra de um determinado escritor e, talvez, nunca cheguem a ler seus principais trabalhos de ficção, tomando conhecimento apenas do enredo principal e algumas frases desses textos através da leitura das resenhas a respeito. São os famosos leitores de resumos de obras e de mais nada.

Algumas refrações críticas são tão detalhadas, didáticas e refratam textos canônicos tão complexos que verificamos, segundo Lefevere (1982a e 1982b), que muitos pesquisadores do âmbito acadêmico, por exemplo, começam suas leituras 
analíticas sobre determinado autor e romance via refrações críticas. A academia incentiva esse aspecto para promover uma maturidade literária sobre narrativas mais complexas e formacão de professional readers, leitores que de fato estudam textosfonte de determinado autor (1992a), além das refrações críticas. O professional reader é aquele que conhece os clássicos da literatura mundial ou cânones, aquelas obras que, ao longo dos anos, foram elevadas a um patamar de importância tal que o público e a crítica não se atrevem a manipular.

Qualquer recolocação de um cânone no mundo atual pode ser, no mínimo, perigosa, pois o responsável por isso, seja ele um autor, tradutor ou adaptador, precisa ser também um professional reader e esse tipo de leitor é cada vez mais raro no cenário da literatura. No caso de uma pesquisa acadêmica, nos parece fundamental ler a maior quantidade de refrações críticas possíveis sobre determinado texto antes de começar a analisá-lo. Concluímos que, no caso de uma pesquisa aprofundada, é essencial que se leia textos-fonte e refrações críticas (uma vez que atuam de forma complementar).

De qualquer forma, as refrações críticas podem desempenhar um papel fundamental: formar o público leitor de determinado escritor em um país. Como exemplo podemos citar as muitas refrações críticas relacionadas à obra de Virginia Woolf publicadas no Brasil dos anos 1940 até 1999. Contudo, pelo menos até 1999 (quando foi publicada a tradução em língua portuguesa "As Horas"), nenhuma delas conseguiu de fato promover um acesso mais representativo aos textos woolfianos. Isso pode ter ocorrido porque especialmente as refrações críticas costumam direcionar os trabalhos refratados apenas para um público mais adepto desse tipo de leitura. Em outras palavras: pessoas relacionadas às diretrizes da academia e do jornalismo, um público restrito. As refrações comuns ou não-críticas têm seu papel. 
Foi exatamente o que aconteceu no Brasil. As refrações publicadas até 1999 atendiam apenas àquelas pessoas ligadas à academia e ao jornalismo. Eram, portanto, e em sua maioria, refrações críticas e muito direcionadas. Não estamos falando de tentar popularizar Woolf, mas afirmamos que faltava um trabalho que pudesse apresentá-la a leitores da atualidade e que não necessariamente a conheceriam pelas discussões intelectualizadas daqueles dois eixos. As refrações que circularam no Brasil até 1999, além das resenhas, foram os próprios romances de Woolf traduzidos em língua portuguesa, a publicação esporádica dos contos em edições coletivas, uma única edição dos Diários de Woolf (1989), as adaptações fílmicas Orlando (1992) e Mrs. Dalloway (1997) e algumas poucas resenhas sobre esses lançamentos. Sim, as traduções são refrações especializadas segundo Lefevere. Todas essas refrações de textos de Woolf foram publicadas de forma inconstante, às vezes em longos intervalos de tempo.

Esse fator (da não reedição de seus trabalhos em ritmo frequente) atesta que essas refrações não conseguiram, segundo nossa conclusão, atingir seu propósito de levar o leitor brasileiro a conhecer e se interessar pela "obra" woolfiana, passando assim a lê-la. Isso denota que não houve um retorno por parte dos leitores, sendo necessário "reescrever" Woolf no cenário atual.

O conceito de "reescrita" de Lefevere (1992a e 1992b) é um sequenciamento de sua ideia de "refração". Os dois conceitos dialogam e se confundem, mas há um aspecto novo abordado: a ideia de manipulação da fama literária pela reescrita, o que nos lembra o caso de The Hours. A esse respeito Lefevere diz (1992b, p. xi): 
Rewriting is manipulation, undertaken in the service of power, and in its positive aspect can help in the evolution of a literature and a society. Rewritings can introduce new concepts, new genres, new devices, and the history of translation is the history also of literary innovation, of the shaping power of one culture upon another.

As "reescritas" precisam de alguma forma dialogar com a atualidade, pois o contexto é importante para o público leitor da atualidade. A ideia de reescrita inclui, assim, a questão da inovação. Ela é, segundo nossa conclusão, um produto final do mercado literário e também o resultado de um processo movido por agentes editoriais, que Lefevere chama de "patronos" (1992b). Segundo ele, há diversas motivações ideológicas por trás das reescritas publicadas na história da literatura, que são a força motora da evolução literária (LEFEVERE, 1992a, p. 02). Repetimos: no caso de The Hours não queremos apontar uma intenção que norteou a escrita dessa obra por Cunningham, mas inferir que o momento de publicação foi oportuno.

Os "patronos" são as grandes empresas que têm relação com o lucrativo mercado editorial: as grandes editoras, os jornais, empresas de publicidade e de mídia. Eles delegam aos editores, professores, tradutores, críticos e revisores o que vai ser publicado, represando certos trabalhos que consideram ruins ou contra a ideologia da época. A "patronagem" se interessa de forma mais objetiva em articular os interesses das empresas com os do mercado, integrando intelectuais e outros públicos leitores. O interesse dos patronos é financeiro, mas é também de status (LEFEVERE, 1992a, p. 14-6).

Deduzimos que, tratando-se do lançamento de The Hours (texto-fonte) nos Estados Unidos, os patronos decidiram que seria rentável reescrever Woolf na atualidade. Para assumir essa proposta, confiaram no já reconhecido trabalho do autor Michael Cunningham. O conceito de reescrita de Lefevere (1992a e 1992b) em The Hours se confirma mais ainda se pensarmos na quantidade de elementos novos 
inseridos por Cunningham ao longo dessa narrativa, como uma exposição mais aberta das vivências homossexuais entre seus personagens, o tema da AIDS, da vida da mulher americana etc.

Sendo assim, afirmamos que The Hours, sob essa perspectiva, é uma reescrita da "obra" da escritora inglesa Virginia Woolf, porque retextualiza não apenas personagens do romance Mrs. Dalloway, mas também elementos de não ficção percebidos por Cunningham nos Diários, Cartas e biografias de Woolf. The Hours refratou-se em uma tradução desse mesmo trabalho no Brasil em 1999 e, a partir daí, em várias refrações dos próprios textos de Woolf de forma mais frequente (reedições, lançamento de inéditos, repercussão do filme homônimo etc.). Portanto, por detrás da "reescrita" da obra de Woolf no Brasil estão envolvidos os processos de tradução e de adaptação ao mesmo tempo.

Nesse bojo, entendemos que é importante discutir mais um pouco o conceito de "adaptação", que se relaciona com o de refração (1982a e 1982b) e reescrita (1992a e 1992b), de Lefevere. Escolhemos o trabalho de Hutcheon (2006) no qual ela analisa particularmente as adaptações fílmicas, mas como se propõe a teorizar essa passagem de um meio a outro como um "processo", acaba por fazer importantes considerações sobre o conceito de adaptação que dialogam com esta tese. Ela acrescenta (2006, p. 07):

Adaptation is repetition, but repetition without replication. And there are manifestly many different possible intentions behind the act of adaptation: the urge to consume and erase the memory of the adapted text or to call it into question is as likely as the desire to pay tribute by copying.

Assim, o conceito de adaptação de Hutcheon (2006) evoca a ideia de uma necessidade de adaptar um cânone baseado em ideologias. Ela diz também que o 
termo adaptação se refere tanto ao produto adaptado (uma adaptação) quanto ao processo de criação desse produto (por reinterpretação e recriação). Adaptação, então, seria a transposição de um ou mais trabalhos reconhecíveis através de um ato de apropriação e resgate. Isso mostra um compromisso intertextual do texto adaptado com o texto fonte que se estende a toda a obra adaptada. Analisar o processo de criação do romance The Hours é uma das tentativas desta pesquisa, visto que The Hours possui elementos adaptados. Isso será feito com base no produto final, o romance em si, levantando hipóteses e nos esforçando para oferecer uma argumentação coerente e sólida.

Para Hutcheon, adaptação é ainda uma nova forma de tradução, como contar a mesma história sob outro ponto de vista. É, portanto, um segundo trabalho, mas não secundário. O termo também pode ser aplicado ao processo de recepção desse mesmo produto (adaptação) pelo público, que ocorre de forma diferente. Nesse caso, temos o público que conhece o texto fonte e o público novo, o que Lefevere (1992a) prefere chamar, respectivamente, de profissional readers e non-professional readers.

Porém, é importante que a obra adaptada estabeleça um diálogo entre esses dois públicos, os que conhecem e os que não conhecem o texto fonte. Nesse sentido, Hutcheon complementa (2006, p. 121):

Indeed, adapters rely on this ability to fill in the gaps when moving from the discursive expansion of telling to the performative time and space limitations of showing. Sometimes they rely too much, and the resulting adaptation makes no sense without reference to and foreknowledge of the adapted text. For an adaptation to be successful in its own right, it must be so for both knowing and unknowing audiences. 
Uma adaptação coerente com a teoria dessa autora é, portanto, aquela que, como The Hours, autoexplicativa. Em outras palavras, uma adaptação não deve exigir dos seus leitores essas referências. Não é preciso conhecer os textos-fonte de Woolf para apreciar e entender o romance do autor/adaptador Cunningham.

Ocorre que o nome adaptação traz sempre consigo a ideia de utilizar algo previamente existente e isso gera expectativas, especialmente porque o nome do autor do texto-fonte figura na obra adaptada. O reconhecimento e a lembrança desse nome fazem parte do contato com a adaptação, assim como também a rejeição pelo distanciamento com o texto-fonte. Por isso é que colocamos as mudanças propostas pelo adaptador como tão importantes e significativas para uma boa recepção da obra adaptada (HUTCHEON, 2006).

$\mathrm{Na}$ medida em que uma obra é publicada como adaptação isso gera um comprometimento maior de representar fidelidade ao texto-fonte e, ao mesmo tempo, ser capaz de atrair novos leitores que desconhecem o texto-fonte. Quando uma editora publica um texto que se não se coloca como derivado, isso dá ao autor uma autonomia curiosa, que lhe permite recorrer a adaptações, sem ter que se comprometer com as origens. As próprias apropriações feitas por Cunningham não fazem com que a editora entenda que essa versão é menos fiel do que seria uma adaptação convencional. Portanto, seria um risco mercadológico publicar esse romance como adaptação. Assim, Cunningham passa a ser valorizado como autor, e não como adaptador. É uma questão de status importante.

O conceito formulado por Julie Sanders é próximo ao de Hutcheon. Sanders (SANDERS, 2006, p. 116) diz (em tradução nossa) que "uma adaptação pode ser uma simples tentativa de tornar um texto 'relevante' ou mais fácil de compreender 
para novos públicos e leitores, através do processo de reconhecimento e atualização desse romance. [...] Também pode ser uma forma de reinterpretação de textos 'primeiros' em novos contextos genéricos, com recolocações do cenário temporal e cultural do texto fonte, que podem ou não envolver uma mudança genérica desse texto".

$\mathrm{Na}$ relação com a tradução (quase sempre vista como mais próxima do original) a adaptação parece ocupar o lugar da transformação, da autoria, da diferença e da criatividade. Mas, quando justaposta ao conceito de apropriação, a adaptação passa a funcionar como tradução, ocupando justamente o lugar da maior proximidade aos textos fontes, enquanto a apropriação torna-se o espaço da diferença, da criatividade e até da radicalidade.

Inferimos que, como adaptação ou apropriação, o romance norte-americano The Hours reinterpreta assim alguns acontecimentos já contados por Woolf em trabalhos anteriores de ficção e não ficção, tudo sob a ótica de Cunningham. Porém, não podemos esquecer que ler esse romance não é um meio de entender, por exemplo, tudo o que se passava na mente da escritora inglesa Virginia Woolf e, tampouco, deve ser tomado como base para o entendimento sobre o suicídio da autora em 1941. Como dissemos, The Hours é feito das interpretações particulares de seu autor para diversos acontecimentos, personagens, nomes e situações descobertas a partir de uma leitura particular dos Diários, Cartas e biografias de Virginia Woolf. A questão analítica mais importante, quando se trata de uma adaptação, não é de julgamento, mas de analisar metodologia, processo e ideologia da obra adaptada (SANDERS, 2006, p. 20). 
Entretanto, na adaptação como produto final, o elemento novo também é fundamental. Vejamos o que diz Lefevere (1992b, p. xi) sobre isso:

But rewriting can also repress innovation, distort and contain, and in an age of ever increasing manipulation of all kinds, the study of the manipulative processes of literature as exemplified by translation can help us towards a greater awareness of the world in which we live.

Ao invés de congregar a ideia da inovação no mesmo conceito, como fez Lefevere (1992b, p. xi) falando da "reescrita", Sanders (2006, p. 26-32) prefere apresentar o conceito de "apropriação". Nele, ela inclui o uso de citações e trechos (embedded texts) de forma velada e não convencional em obras tratadas como inéditas:

The gesture towards the source text(s) can be wholly more shadowy than in these explicit situations, and this brings into play, sometimes in controversial ways, questions of intelectual property, proper acknowledgment, and, at its worse, the charge of plagiarism.

Por conta dessa primeira definição, o conceito de apropriação se revela inicialmente polêmico e pode levar a discussão sobre adaptações inclusive para o campo da ética, conforme faremos adiante. Contudo, podemos entendê-lo também como um processo de elaboração em romances inéditos como The Hours e em uma adaptação que, ao invés de mostrar apenas similaridades com o texto clássico, infere as novas propostas/ideologias do seu autor/adaptador e suas reformulações, muitas vezes radicais.

Apropriar-se significa tornar algo próprio. Nesse aspecto, o adaptador que usa apropriação faz um cruzamento interessante na obra adaptada: torna suas as questões do autor canônico. Também levanta questões do texto-fonte pouco 
exploradas ou nem sequer percebidas, tornando-as objeto de discussão dentro de sua proposta narrativa. Ao final, especialmente o leitor que não conhece os clássicos (os non-professional readers) é sugestionado a não saber o que de fato foi "reescrito" ou "adaptado".

Já ao leitor profissional, que conhece os textos-fonte, cabe sua avaliação sobre como essa apropriação se desenhou na proposta de leitura final da obra adaptada. Esse conceito é fundamental na discussão que propomos nesta tese: a de colocar nas apropriações de Cunningham o grande potencial de reescrita do romance The Hours. Na verdade são os novos elementos propostos por Cunningham que reescrevem a "obra" de Woolf na atualidade. Portanto, vemos como mérito de uma adaptação literária a apropriacão de questões atuais, como fez Cunningham. Ele forma um diálogo com textos anteriores de Woolf em uma narrativa contemporânea. Portanto, se fossemos classificar o romance The Hours entre adaptação ou apropriação, ele seria, sem dúvida, uma apropriação.

Então há uma proposta criativa na ideia de apropriação que nos interessa e que procuramos perceber em The Hours. Há temas percebidos pelo autor/adaptador que se transformaram em abordagens novas. Isso pode dar origem a diversos pontos de criação na adaptação, o que inclui, por exemplo, a temática da AIDS. A respeito das políticas trazidas pelas apropriações, Sanders (2006, p.98) acrescenta:

\footnotetext{
Many appropriations have a joint political and literary investment in giving voice to those characters or subjectpositions they perceive to have been oppressed or repressed in the original.
}

Em resumo, as apropriações de Cunningham em The Hours são especialmente baseadas nessa proposta de incluir temas inéditos e situações contemporâneas percebidas por ele. O texto apropriado interage com o texto fonte 
gerando novos significados, novas interpretações e ressonâncias. O resultado final é a concretização de um romance com todo o aspecto de originalidade que os modernistas ingleses, por exemplo, esperavam alcançar nos anos 20 do século XX. E ocorreu da mesma forma com os ingleses buscando ineditismo. Inclusive algumas críticas aos trabalhos de modernistas ingleses eram baseadas no que os escritores haviam "adaptado" (e não criado). Foi assim que alguns poucos criticaram o "Ulysses" de James Joyce, por adaptar o clássico A Odisséia, de Homero.

Entedemos, assim, que adaptar ou apropriar-se de elementos de textos canônicos para a criação de novas narrativas é algo possível. Aliás, como vimos isso é bastante comum em literatura e deveria ser tratado como tal. O mérito de Joyce e de Cunningham é ter conseguido fugir da obviedade da simples imitação e desenvolver obras com um enredo sólido, personagens profundos e alcançar o reconhecimento da crítica literária.

No trabalho de Linda Hutcheon (2006) há uma teorização importante sobre o profissional que ela chama de "adaptador". No caso de um filme, o adaptador é todo aquele que se envolve no processo de adaptação de um ou vários textos-fonte para o formato audiovisual: o diretor, os atores, o roteirista, o figurinista etc. Lefevere (1992a, p. 13) se referia a todos esses profissionais como rewriters. Trazendo esse conceito para o cenário exclusivo da literatura, já que temos como corpus desta pesquisa um romance que adaptou e se apropriou de elementos de outros textos, encontramos dois adaptadores principais: o tradutor e o adaptador literário, ambos rewriters (LEFEVERE, 1992a e 1992b). Para o mercado editorial, esses são profissionais diferentes porque, ao adaptador, é dada uma maior liberdade de criação literária (interferência nas questões da narrativa), sendo essa liberdade às vezes contratada juridicamente. Isso é devido à ideia de que a adaptação no 
mercado editorial parte de uma proposta que pode ser a decodificação de signos linguísticos, de marcas textuais, a interpretação de metáforas, a simplificação da linguagem, a "refração" de uma personagem de obra canônica etc. Tudo isso acontece sob o ponto de vista do adaptador, ou pela necessidade de atender as diretrizes impostas pela editora. Essas diretrizes, como já dissemos, provem de ideologias do adaptador e também do grupo de agentes envolvidos com a publicação editorial dessa adaptação.

Por enquanto, ressaltamos apenas que Michael Cunningham usa isso a favor da narrativa que propõe, porque dialoga com temas particulares e atuais, como a causa gay. Hutcheon parece concordar com essa proposta nas adaptações quando $\operatorname{diz}(2006$, p. 107):

Political, aesthetic, and autobiographical intentions of the various adapters are potentially relevant to the audience's interpretation. They are often recoverable, and their traces are visible in the text. The political dimension - in, for instance, feminist, queer, postcolonial, race, or ethnic studies - has been rescued.

Também percebemos uma diretriz editorial recorrente em adaptações: sugerir que o adaptador promova uma linguagem menos complexa ao clássico adaptado, o que não é o caso de The Hours. Segundo Emer O'Sullivan (2006, p. 151) esse procedimento é bastante aplicado, pois é imprescindível que se "adapte o texto fonte às normas literárias e tradições da cultura alvo, para que, assim, o texto seja mais bem recebido pelos novos leitores em questão" (tradução nossa). Dessa forma, esse autor frisa o caráter didático que cumprem algumas adaptações. O próprio conceito de boa literatura, segundo Lefevere (1992a, p. 03), também sugere isso: traduzir um texto pensando em seu público (grifo nosso), como fizeram os irmãos Charles e Mary Lamb $(1933,1956)$ quando adaptaram Shakespeare para crianças. Isso 
aconteceu porque a leitura em drama das peças de Shakespeare ficaria restrita a leitores familiarizados com esse gênero.

Assim, a ideia dos primeiros editores que propuseram adaptar peças de Shakespeare foi de publicá-las em linguagem mais próxima dos romances modernos, aproximando Shakespeare de non-professional readers (LEFEVERE, 1992a). Editoras como a Longman publicaram adaptações de peças shakespearianas para crianças, em forma de conto e em linguagem bem familiar pelos Lamb. Eles fizeram as adaptações que julgaram pertinentes (principalmente nas tragédias) para que a obra shakespeariana dialogasse também com o público infantil.

No Brasil, um exemplo dessa valorização em torno das adaptações intralinguais pode ser atribuído à obra clássica Os Lusíadas, de Luís Vaz de Camões (1572). Dada sua importância histórica e cultural, esse épico é bastante trabalhado nas aulas de Literatura Portuguesa das escolas nacionais (sejam públicas ou privadas) e cobrado em diversos vestibulares de universidades nacionais. Nessa perspectiva, muitas instituições de ensino encomendaram adaptações às editoras. Rubem Braga (1987), autor brasileiro aclamado pela crítica literária nacional, foi um dos adaptadores e, ao seu trabalho de retextualização, sucederam outros. É sabido que é bastante comum no mercado literário brasileiro encontrarmos clássicos da literatura mundial "recontados" por grandes escritores nacionais.

Além do viés pedagógico das adaptações, é também comum nos deparamos com textos contemporâneos internacionais em narrativas inéditas que adaptaram elementos de obras anteriores, como é o caso de The Hours. Tanto pela forma nova como pela grande quantidade de elementos inseridos pelo autor/adaptador nesse 
texto (apropriações), estabelecer as ligações precisas de The Hours com seus textos-fonte é algo complicado para o público como um todo (professional e nonprofessional readers). São personagens, nomes e acontecimentos que foram reproduzidos de vários textos e contextos, reiterando a forte presença da intertextualidade a que Graham Allen (2000) se referiu em seu estudo. Assim, quando as editoras não conseguem estabelecer essas ligações com o texto-fonte de forma clara, elas optam por não classifcar a narrativa como adaptação. É quando as apropriações são mais evidentes e a obra é realmente inédita.

As adaptações e apropriações presentes em romances contemporâneos são completamente intencionais, e essa prática, como já dissemos, é bastante comum na literatura desde seu início. O que podemos perceber é que, no Pós-Modernismo, ela tem sido mais valorizada. O romance The Hours utiliza elementos adaptados e apropriados de alguns livros de Virginia Woolf (1882-1941), em meio a novos elementos, personagens, roupagens e cenários, organizados de forma bastante criativa por Cunningham.

Esse autor utilizou os fluxos de consciência de Woolf percebidos por ele nos Diários (1980), em Mrs. Dalloway (1925) e nas Cartas (1982) para construir três personagens centrais em The Hours (1998), dividindo o livro em capítulos (intitulados Mrs. Brown, Mrs. Dalloway e Mrs. Woolf) nos quais as descrições de cada uma delas se sucedem de forma alternada.

Ademais, Cunningham foi buscar nos diários de Woolf, principalmente no segundo volume (1980), a inspiração para descrever em The Hours (1998) um período na vida da própria Virginia Woolf, que também atua como personagem do 
romance. Cunningham narra as memórias da autora inglesa ao escrever Mrs. Dalloway (1925) e também os últimos dias de sua vida.

Cunningham pode ser visto como alguém que recoloca a leitura sobre vida e obra de Virginia Woolf no mundo, pois nunca se falou tanto nessa escritora desde a publicação do livro e a veiculação do filme (1998 e 2002, respectivamente). The Hours foi publicado apenas três anos antes do aniversário de 60 anos da morte de Woolf, comemorados em março de 2001. O aniversário de nascimento e morte de um escritor costuma ser um momento editorial/comercial bastante propício para as editoras. Nessas datas, elas geralmente republicam clássicos no intuito de relembrar ao público a importância da obra desses escritores, mas podem também incluir reescritas que os homenageiam, como The Hours.

Talvez Cunningham tenha acreditado que refratar (LEFEVERE, 1982a e 1982b) uma Mrs. Dalloway em tempos modernos, por exemplo, seria bastante conveniente naquele momento literário (o ano de 1998, final do século XX). Assim, criou uma nova Clarissa, dessa vez moradora de Nova lorque no final dos anos 1990 e que se prepara para dar uma festa (para seu amigo Richard), tal qual fez Clarissa Dalloway no romance de Woolf.

Lefevere (1992a, p. 7) nos diz ainda que algumas reescritas são inspiradas por motivações ideológicas (de Cunningham, nesse caso) e pela convergência dos reescritos com "motivações atuais", o que também nos remente ao conceito de apropriação de Sanders (2006). As motivações ideológicas de Cunningham delineiam toda a narrativa e dão o desfecho a personagens como Richard e a própria Woolf. São questões que não foram aprofundadas nos diários, cartas ou em Mrs. Dalloway, mas que Cunningham quer contar (ou tornar próprias dele). Talvez 
Woolf tenha passado por elas de forma sutil, mas Cunningham queria mais, por isso norteia seu romance no sentido de suas preferências.

As reescritas manipulam e são eficazes, além de funcionarem sempre em adaptações para filme (2002) ou TV (LEFEVERE, 1992a, p. 07). É que o audiovisual congrega muitas vezes os professional e os non-professional readers. Então a partir de um filme, muitos cinéfilos procuram ler o romance (texto-fonte) e muitos leitores também procuram assistir as adaptações para julgá-las. Há, então, uma grande convivência entre literatura e cinema na atualidade, o que favorece os autores dos textos-fonte, adaptadores e novos autores.

Woolf e Cunningham, sem dúvida, passaram a ter uma visibilidade mundial maior ainda com a adaptação fílmica The Hours (2002). Os patronos cinematográficos inclusive perceberam que o romance de Cunningham já continha naturalmente formato e linguagem cinematográfica, como o monento em que a personagem Clarissa Vaughan diz ter visto alguém na rua que se parecia com Meryl Streep ou com Vanessa Redgrave (1999, p. 28). Convém lembrar que Cunningham colaborou junto com David Hare no roteiro do filme The Hours e também aparece em uma cena do início desse longa-metragem como figurante. Meryl Streep foi a atriz que representou Clarissa Vaughan a pedido de Cunningham nessa adaptação.

Algumas semelhanças com trabalhos de Woolf são percebidas pelo leitor familiarizado logo no início de The Hours (1998, p. 6-7), como a carta de suicídio deixada ao esposo Leonard. Essa carta é apresentada como prólogo de The Hours e foi adaptada a partir do Letters vol. VI (1982). Essa identificação continua ocorrendo por toda obra, seja com menções biográficas provavelmente recriadas a 
partir do Diaries vol. II (1980), seja com a utilização de elementos do romance Mrs. Dalloway (1925).

Sendo assim, Cunningham decide dar seguimento à história por meio de mais uma apropriação em The Hours: ele cria Laura Brown, que também representa a natureza humana nesse romance. Ela está infeliz e até cogita a possibilidade de suicídio. Opta por não confrontar essa realidade, mas dela fugir, como é apresentado ao leitor ao final do romance. Fuga essa, concluímos, que também é trabalhada como possibilidade de solução para as questões vividas pela personagem.

A atualidade sobre a qual discorre Lefevere (1992a) quando se refere às reescritas é bastante evidente nas personagens Laura Brown e Clarissa Vaughan, o que promove a identificação do público leitor (1998) e espectador (2002). Elas atualizam Woolf e Clarissa Dalloway em situações domésticas problemáticas do século XX. Lefevere (1992a) afirma ainda (1982a, p. 18) que, antes de publicar uma reescrita, alguns questionamentos são feitos, como: o livro pode trazer à tona a discussão em torno de Virginia Woolf? Parece comercialmente rentável? Tem chances de ser traduzido? $\mathrm{O}$ argumento pode virar filme? A resposta a cada uma dessas perguntas parece positiva.

Concluindo: em The Hours (1998) Cunningham, leitor de Woolf, atendeu a interesses pessoais quando publicou esse romance. Mas são as apropriações colocadas por ele no enredo de The Hours que de fato reescrevem a "obra" de Woolf no período recente. Isso ocorre porque essas apropriações dialogam de forma mais dinâmica com os leitores contemporâneos pela escolha assertiva dos temas levantados pelo autor. 


\subsection{0 romance The Hours}

Nacionalmente, existem algumas obras de referência acadêmica que já pesquisaram esse romance. Podemos citar o trabalho de Carlos Silva (2007) que, conforme já dissemos, investiga a construção de uma Mrs. Dalloway pós-moderna na adaptação fílmica de 1997 e depois em The Hours (1998 e 2002). O autor também trabalha especialmente com o conceito de reescrita de Lefevere (1992a) para analisar a tradução dessa personagem por Cunningham e também pelos diretores das adaptações fílmicas.

Temos ainda o artigo da professora Genilda Azeredo (2005) e o livro da professora Thaís Diniz (2005), ambos direcionados especialmente à releitura desse romance no cinema. Nossa intenção, portanto, não é esgotar o debate sobre The Hours, mas mostrar que ainda há possibilidades de investigação nesse contexto, por conta da natureza intertextual dessa narrativa.

Em The Hours o autor constrói sua narrativa com base em três personagens principais e em cenários distintos. Porém, em determinado momento, as histórias se entrecruzam. A técnica estilística empregada por Cunningham em The Hours (1998) é a mesma trabalhada por Woolf em Mrs. Dalloway (1925): o monólogo narrado ou discurso indireto livre. Nessa técnica, segundo Dorrit Cohn (2000, p. 494-7) ocorre a passagem da linguagem figurativa do pensamento da personagem para dentro da narrativa textual em terceira pessoa. Essa é uma forma de dar mais autenticidade e autonomia psicológica às personagens e de mostrar que o discurso pertence muito mais a elas que ao narrador. Podemos perceber o discurso indireto livre quando, por exemplo, o narrador imita a voz de uma personagem falando consigo mesma. Abre- 
se então uma diferença entre fato narrado (pelo narrador) e um pensamento da personagem.

Logo no início da narrativa, Cunningham faz uma introdução (em terceira pessoa) para descrever a caminhada de Woolf até o rio onde se afogou. Tudo isso é feito com base na leitura dos diários, biografias, cartas e, principalmente, em uma carta de suicídio deixada por ela. Em seguida, ele apresenta essa carta como se quisesse que Woolf (personagem) pensasse alto. As personagens, segundo constatamos, são estratégias de Cunningham para "contar" sua versão sobre determinadas passagens de textos woolfianos que serviram de inspiração à obra.

Em "a note on sources", o autor (1998, p. 229) menciona que, além dos três romances citados, teve também acesso a várias biografias acerca da vida da escritora, além de prefácios de vários editores das obras publicadas e diversas outras fontes que o ajudaram a construir seu romance. Então, reiteramos nossa conclusão parcial, de que esse autor tentou contar várias histórias relacionadas à escritora inglesa Virginia Woolf e, principalmente, atualizar passagens e personagens do romance Mrs. Dalloway na contemporaneidade. Também introduz novos temas, ora apropriando-se de questões semelhantes ventiladas por Woolf, ora colocando outras completamente novas.

A reconfiguração da personagem principal homônima do romance Mrs. Dalloway em duas outras (Clarissa Vaughan e Laura Brown) é outro ponto interessante de The Hours. A personagem do romance homônimo de Woolf (1925) "renasce" como personagem de mesmo pré-nome (Clarissa), mas agora vivendo na cidade de Nova lorque no final dos anos 1990. Essa semelhança parece inicialmente uma tentativa de Cunningham trazer a Mrs. Dalloway de Woolf para a 
contemporaneidade. Por isso, afirmamos que a personagem Clarissa Vaughan mostra o grau de comprometimento do escritor americano com a possibilidade de integração dos textos de Woolf na atualidade.

A segunda personagem, Laura Brown, parece "reencarnar" a Mrs. Dalloway do texto original sob o olhar crítico e descritivo do autor. Brown mora em um subúrbio de Los Angeles (Estados Unidos) nos anos 1940. Cunningham, nesse momento, atua como interlocutor entre Woolf e Brown. Ele capta todo sofrimento, solidão e nostalgia dessas personagens. Assim, ele descreve Laura Brown como leitora do romance woolfiano Mrs. Dalloway, dona de casa, infeliz no casamento com Dan, com desejos secretos, reprimidos e, enfim, angustiada com a situação de vida que se apresenta a ela. Seu filho Richie parece perceber o sofrimento da mãe, mas ele é apenas uma criança.

O nome da personagem Laura Brown e outras características de sua personalidade foram reproduzidos do ensaio Mrs. Bennet and Mrs. Brown (WOOLF, 2000). Nesse ensaio, Woolf rebate as críticas do escritor Arnold Bennet ${ }^{9}$ relacionadas aos seus romances, ao mesmo tempo em que critica a ele, e também aos autores H. G. Wells e John Galsworthy. Woolf defende uma nova forma de escrever romances de ficção àquela época (anos 1920) e esses autores eduardianos, mais tradicionalistas, estariam então na via contrária à sua proposta.

O nome Brown surge logo no início do ensaio, quando Woolf conta uma história que na verdade pretende tratar do velho e do novo, do tradicional e do

\footnotetext{
9 Arnold Bennet (1867-1931) foi um escritor inglês que publicou suas obras em período contemporâneo ao de Woolf. Apesar de ser amplamente bem reconhecido naquela época, Bennet foi frequentemente criticado por ela em seus ensaios por ser tradicional. Woolf defendia uma nova proposta literária em temas e formas narrativas que ficou conhecida como modernismo inglês. Em resposta às críticas da autora, Bennet disse que a ela seria incapaz de criar personagens eternos.
} 
antigo, do fazer o que se espera ou fazer oposição ao que não agrada. Ela conta que, certa vez, viu duas pessoas no trem (um homem e uma mulher de idade) e começou a descrever o comportamento dos dois através de divagações ficcionais. $\mathrm{O}$ homem ela chamou de Mr. Smith e, a mulher, de Mrs. Brown. Nesse casal, o homem parecia ter certo poder sobre a mulher. Na história criada por Woolf os dois travam um diálogo bem seco, no qual fica clara a dependência emocional de Brown por Smith. Logo em seguida, Mr. Smith deixa o trem e Mrs. Brown começa a chorar. Com essa metáfora, Woolf quer ilustrar como Arnold Bennet (o Mr. Bennet do título) e outros autores eduardianos são obcecados apenas com a construção de personagens, quando, na verdade, deveriam se voltar mais à natureza humana (representada pela Mrs. Brown). Essa personagem representaria inclusive o público leitor daquela época que, desapontado, não se vê representado em obras como as de Arnold Bennet.

Brown está grávida de seu segundo filho. Sua vida parece perfeita aos olhos dos outros, mas ela vive angustiada. Percebemos, através do discurso de Cunningham sobre essa personagem, que ela é a grande heroína desse romance, inclusive porque ele se faz mais presente nas narrações dedicadas a ela. Isso se repete ao final, quando as personagens Clarissa Vaughan e Laura Brown se encontram. A partir desse momento, o que se vê são os discursos das duas personagens dando o desfecho da história.

As atitudes, pensamentos e discursos de Laura Brown, descritos por Cunningham (1998), ora lembram os da personagem Mrs. Brown do ensaio de Woolf (2000), ora lembram Clarissa Dalloway do romance Mrs. Dalloway. O autor mostra, através da descrição de Laura Brown nos anos 1940, que ela vivia como a Clarissa de Woolf (1925), fazendo as mesmas coisas banais e sofrendo por isso. Era infeliz 
no casamento, como a Clarissa de Woolf (1925) e tem anseios distintos. A Mrs. Brown do ensaio de Woolf (2000, p. 747) é descrita como "alguém com um olhar de sofrimento, apreensão, que deixou para trás uma vida perturbada" (tradução nossa), tal qual Laura Brown em The Hours.

A terceira protagonista de The Hours é a própria escritora inglesa Virginia Woolf, que aparece no prólogo em 1941, ano de sua morte. Depois, ela reaparece no capítulo 2 (“Mrs. Woolf”) nos arredores de Londres (Inglaterra), onde vivia em 1923, época em que escrevia o romance Mrs. Dalloway. Na passagem de 1923, nos parece que o anseio principal do autor foi mostrar o processo de criação daquele livro por Woolf. Ele nos mostra a escritora inglesa imaginando qual o enredo principal daria para a personagem central do romance, Clarissa Dalloway. Em seguida, decide descrever um dia "comum" na vida de Clarissa, no qual ela daria uma festa em homenagem a um amigo.

No antepenúltimo capítulo de The Hours, a vida de Woolf volta a ser contada em apenas mais duas páginas para retratar sua mente confusa, já bastante acometida pelos distúrbios psiquiátricos que a perturbaram durante toda sua vida, e que, naquele momento, tornaram-na impotente. Ela não podia sequer escrever, nem ler, nem sair sozinha.

Por fim, entendemos que Cunningham apresenta sua visão sobre uma mulher dos anos 1940, outra no final dos anos 1990 e também sobre a vida da escritora inglesa Virginia Woolf dos anos 1920 aos 1940. Percebemos em The Hours três discursos, em épocas, lugares e ambientes distintos que, na verdade, refletem uma possível intenção do autor: a de promover uma revalorização da obra de Virginia Woolf com base em sua leitura particular dessa mesma obra. Segundo Hutcheon 
(2006, p. 107) as intenções políticas, estéticas e autobiográficas dos adaptadores são potencialmente relevantes para a interpretação do público e seus traços são bem visíveis no texto-fonte. Assim, percebemos uma convivência de discursos que espelha as intenções narrativas de seu autor/adaptador.

\subsection{Michael Cunningham e a questão ética}

A inspiração em escritores do cânone é algo bastante comum para os escritores da atualidade, e essa inspiração inclui citações e intertextualidade adaptadas em trabalhos inéditos. Começaremos esse debate, então, mostrando uma declaração de Michael Cunningham sobre quem o inspirou. Em entrevista traduzida e publicada no jornal O Estado de São Paulo ele descreve o quanto a leitura de Woolf e Joyce o influenciaram (CUNNINGHAM, 2011b):

Difícil é imaginar muitos escritores contemporâneos que não sejam influenciados por ela. [...] Woolf e Joyce, juntos, são os maiores modernistas, e muito do que introduziram na literatura se tornou parte do gênero desde então. Eles escreveram sobre personagens que parecem ordinários, ao contrário de heroicos. Eles insistiam que cada pessoa embarcava na sua própria viagem épica, ainda que a vida da maioria, vista de fora, parecesse consistir em trabalho e casamento, saídas triviais e sestas. [...] Qualquer autor contemporâneo que capricha no som de uma frase, nas suas qualidades musicais, tem uma dívida com Woolf e Joyce.

Percebemos que, como Woolf, Cunningham também não compõe suas narrativas pensando em acontecimentos ou personagens específicos, mas no perfil psicológico de algumas poucas personagens em um dia comum. Assim, se mostra um verdadeiro discípulo de Woolf e Joyce. Em outro depoimento (2011a), Cunningham revela que o romance Mrs. Dalloway (WOOLF, 1925) de forma mais direta foi seu grande impulso para a criação de The Hours (1998) e mostra o prazer que tem de falar sobre esse como seu primeiro e inesquecível romance. 
Percebemos, assim, o olhar desse escritor para esse texto-fonte e sua curiosidade e ansiedade em tentar reproduzí-lo para leitores da atualidade.

Porém, a utilização de elementos de um texto-fonte em uma nova narrativa eventualmente gera debates no campo da ética. De acordo com verbete do The Cambridge Dictionary of Philosophy (1999, p. 283-4), podemos definir ética como sendo o estudo filosófico da moralidade e da ação correta. No mesmo verbete, encontramos ainda referências ao termo "princípios morais". Sabemos que em The Hours (1998) seu autor recebeu permissão legal para adaptar e se apropriar de elementos dos livros Mrs. Dalloway, The Diary of Virginia Woolf vol. II e The Letters of Virginia Woolf vol. VI. Não haveria, portanto, nenhuma transgressão ética/legal. Mas a falta de critérios definidos por editoras e autores para o uso indiscriminado desses textos-fonte muitas vezes gera polêmica. Cunningham, por exemplo, reproduziu trechos de cartas de Woolf diretamente do texto-fonte, dentre outros elementos adaptados. Também se apropriou do título provisório que teria o romance Mrs. Dalloway e o deu à sua narrativa. Por fim, recontou vários momentos relatados pela autora inglesa em seus Diários e Cartas.

Questionamos então qual seria o limite ético para adaptar, atualizar, reescrever, refratar, interpretar ou apropriar-se de elementos de um texto literário primeiro. Há esse limite? Qual o parâmetro para fazer isso? Normalmente, esse parâmetro é dado pelas editoras ou pelos autores. Queremos dizer com isso que, muitas vezes, algumas obras adaptam elementos de outras anteriores, intralingualmente ou interlinguisticamente, para se promoverem e a seus escritores. Eles seguem diretrizes de agentes que pretendem lançar o novo trabalho baseandose e aproveitando-se também na figura do reconhecido autor de um texto canônico. 
Não há limites para o que as editoras pretendem alcançar com elementos adaptados de textos canônicos. É sabido que, como fez Cunningham em The Hours (1998) em relação a personagens, nomes, trechos, acontecimentos, biografia e cartas de Woolf, também o fazem muitos escritores, não talvez com a mesma aceitação por parte do público leitor e da crítica literária especializada.

Assim, consideramos que a procura por parte dos leitores especialistas (professional readers) pela semelhança com elementos de um texto-fonte canônico é o que causa desconforto e convoca muitas adaptações ou narrativas com elementos adaptados para serem discutidas no campo da ética. Essa procura pode levar o especialista a encontrar ou não essas semelhanças com o texto primeiro e, nesse caso, as diferenças serão a base para a crítica, até hoje centradas na questão da fidelidade.

Mas como funcionaria, em termos de permissão editorial, a adaptação acordada de elementos de um texto literário? A editora precisaria especificar no contrato de compra dos direitos autorais dessa primeira obra que ela será publicada como adaptação, ou que terá alguns de seus elementos adaptados. Assim, o correto seria que, ainda como projeto editorial, a editora tomasse esses cuidados. Quando essas medidas são tomadas, há um acordo pré-estabelecido de cessão de direitos e uso do texto-fonte. Dessa forma, qualquer acusação de plágio pode ser rebatida pela editora.

Outro caso ocorre quando as obras literárias de qualquer autor chegam ao chamado "domínio público" - após setenta anos da morte do escritor. Nesse contexto, passa a ser permitido a qualquer editora traduzir, retraduzir, publicar como adaptação ou apenas adaptar elementos de um texto original, ainda que o resultado 
possa ser bastante passível de crítica. Isso aconteceu a partir de março de 2011 com os romances de Woolf no Brasil. Entendemos que é a partir daí que começam os questionamentos envolvendo o tema da ética.

Baker (1998, p. 5), em verbete sobre o tema da adaptação, alerta que as adaptações assim categorizadas não deverão ser reconhecidas como tradução de um texto-fonte, afirmando que por trás do termo existem palavras mais polêmicas, como é o caso de "imitação". Ela explica:

Adaptation may be understood as a set of translative operations which result in a text that is not accepted as a translation but is nevertheless recognized as a representing a source text of about the same length. As such, the term may embrace numerous vague notions such as imitation, rewriting, and so on.

A palavra "imitação", em leituras da Filosofia, também nos remete ao tema da adaptação. Essa conexão se evidencia no ponto em que o texto adaptado parte da imitação de outro, ainda que novos elementos sejam colocados na obra mais recente. Na época clássica, a questão da imitação no contexto da produção de novos trabalhos de literatura era tratada com bastante naturalidade, sendo inclusive algo estimulado. Isso nos faz perceber uma corrente de pensamento bastante antiga que defende a realização dessa prática pelos que aqui chamamos de adaptadores no contexto das adaptações literárias, embora sabendo que ainda não existia a ideia de direito autoral e textos como os de Platão (2005) reiteram isso.

E por que então algumas adaptações publicadas na atualidade causam tanto mal-estar na crítica literária especializada e em muitos leitores? A resposta envolve a figura do adaptador. 
A ideia de discutir o papel do adaptador surgiu a partir de uma colocação de Pym (2001, p. 137). Esse autor afirma que, no contexto dos debates sobre ética, o foco primeiro recai sobre as pessoas e só depois nos textos. Explicando: ele fala de textos que reproduziram elementos de outros textos-fonte e reitera a importância de se estudar os autores desses novos-textos, suas ideologias e intenções. Quer dizer ainda que, na atualidade dos Estudos da Tradução, as pesquisas levam muito em consideração o que chamamos de contexto de tradução, o que diretamente leva em conta o profissional-tradutor.

Então não há como analisar a problemática em torno da adaptação de uma narrativa sem analisar o adaptador. Reforçando um ponto importante: uma vez sob a classificação de obra adaptada, a editora julga poder utilizar o argumento do texto de partida (usando um termo dos Estudos da Tradução) como lhe for conveniente. Ela (a editora-empresa) direciona qualquer princípio moral e ético em prol dos seus interesses e encontra adaptadores que executam a tarefa de adaptação proposta por ela.

Acreditamos que a motivação ideológica e comercial das editoras com relação ao lançamento de adaptações seja atrair outro público para o conhecimento dessas narrativas. Do outro lado, temos o público que já conhece o texto inicial (os fãs). Como o texto adaptado se propõe (enquanto utiliza o nome do texto de partida e seu autor) a fazer referência à primeira obra, esses leitores buscarão exatamente a familiaridade e o reconhecimento. Muitas vezes, eles serão surpreendidos por uma visão que se afasta bastante do que conhecem.

Robert Eaglestone (2005, p. 137), em trabalho sobre a questão da ética e seguindo a mesma linha de conceitos de Lefevere (1992a), parece dizer a tradutores 
e adaptadores que se sintam à vontade para adaptar trabalhos por iniciativa própria ou por uma proposta editorial, sem qualquer constrangimento de ferir a ética e os princípios morais citados há pouco, por considerar que a obra adaptada tenha se afastado do texto inicial.

Assim, entendemos que os autores contemporâneos, de maneira geral, precisam se preocupar mais com o público a que nos referimos há pouco, inclusive com aquele que vai começar a "ler" clássicos a partir de adaptações. Recordamos ainda mais um caso em que a publicação de uma obra como adaptação pode vir a gerar discussões em torno da ética do tradutor ou do adaptador, qual seja: o uso da imagem do autor para facilitar o reconhecimento da obra e também a utilização de tradutores, escritores ou adaptadores renomados para agregar valor a uma publicação. Vejamos: durante a primeira fase de publicação dos romances de Woolf no Brasil $^{10}$, as editoras da época convidaram escritores de renome no cenário nacional - Mário Quintana para traduzir Mrs. Dalloway (1946) e Cecília Meireles para traduzir Orlando (1978). Por qualquer motivo (mesmo que fosse a ausência de tradutores literários conhecidos para realizar essa função nos anos 1940), essa foi sem dúvida uma estratégia para favorecer a recepção de Virginia Woolf pelo público leitor desse período. Para tanto, trataram de promover uma interlocução entre leitores desses escritores e os propensos leitores de Woolf.

O feito se repetiu na segunda fase de publicações, com o convite para Lya Luft traduzir A viagem (1993) e retraduzir As Ondas (2004). Um ponto a ser analisado é que esses escritores se declararam em entrevistas diversas como verdadeiros fãs do estilo woolfiano. É possível que uma das variáveis analisadas

\footnotetext{
${ }^{10}$ Trabalharemos as fases de publicação dos romances de Woolf no Brasil no capítulo 3.
} 
pelas editoras tenha sido a de procurar tradutores-escritores com um estilo no mínimo parecido com o de Woolf, se é que isso é possível.

De fato, essas traduções foram muito bem recebidas pela crítica literária especializada. Esse fato nos remete ao conceito de "visibilidade" formulado por Venuti (2004), e essa situação ainda não se revela em fato comum no mercado de tradução: tradutores destacados pelo atual sistema de divulgação das publicações (traduções). É que no percurso de reconhecimento do valor de uma obra estrangeira em outro país ou sistema há que se ter cautela com a relação autor $\mathrm{X}$ tradutor.

Algo diferente ocorreu depois do lançamento no Brasil de As Horas (1999), com tradução de Beth Vieira, ${ }^{11}$ e da publicação de alguns ciclos de tradução dos romances de Woolf: formou-se um grupo de leitores da escritora inglesa em território nacional. As mídias impressa e eletrônica destacaram As Horas (1999) como o romance que tinha Virginia Woolf como uma de suas personagens. A partir daí, pouco se falou em Michael Cunningham - o autor - e muito se falou em Virginia Woolf. O filme lançado aqui em 2002 também explorou esse lado.

Dessa forma, as imagens e personagens de Woolf apropriados por Cunningham e pelo diretor do filme homônimo de certa forma sufocaram sua autoria, mas, sem dúvida, divulgaram ou reescreveram a "obra" de Woolf para um público mais amplo. Acreditamos que o texto adaptado corre mais risco de ser criticado porque utiliza um texto inicial como mola propulsora para sua possível aceitação pelo público leitor e pela crítica literária, passível, portanto, de inevitáveis comparações com obras anteriores. O confronto ético das adaptações e de obras que, como The Hours (1998), adaptaram elementos de textos já publicados, na

\footnotetext{
${ }^{11}$ Título nacional do livro The Hours, de Michael Cunningham.
} 
verdade não se relaciona apenas às identificações entre ambos, mas à qualidade dos mais recentes e, principalmente, às apropriações colocadas pelo autor contemporâneo.

Em suma, os elementos reconfigurados do texto inicial não são suficientes para fazer da adaptação um texto lido por muitos, conforme desejavam a editora ou o novo autor. O tradutor e o autor/adaptador precisam então também ser escritores criativos, versáteis, preocupados com a questão da empatia com a leitura, com a assimilação da história e do enredo pelo público leitor. Os críticos, assim, não julgaram a reescrita dos textos de Woolf em The Hours (1998) com base em aproximações ou afastamentos de Mrs. Dalloway, dos Diários e das Cartas, mas através da qualidade do texto de Cunningham, que supera a maior parte dos questionamentos. 


\section{CAPÍTULO 2 - ADAPTAÇÕES E APROPRIAÇÕES EM THE HOURS}

\subsection{Metodologia}

Neste capítulo, pretendemos destacar exemplos de trechos que inspiraram Cunningham em The Hours (1998) e discuti-los à luz dos conceitos apresentados anteriormente, especialmente relacionando o que foi "adaptado" e/ou "apropriado" segundo Sanders (2006). Isso será feito através da compilação de alguns trechos ou descrição de temas adaptados dos Diários (1980) e das Cartas (1982). Esta será, então, a forma que escolhemos para estudar o processo de criação do romance The Hours (1998).

Com relação a Mrs. Dalloway (1925), descreveremos as principais interextualidades entre The Hours e esse texto. Encontramos pesquisas como a tese de Silva (2007) e mesmo a descrição de Sanders (2006) que mostram algumas dessas intertextualidades. Vamos citá-las, acrescentar outras e descrever como foram propostas por Cunningham, conforme nosso entendimento de adaptação.

Os trechos compilados dos diários e cartas serão apresentados em Inglês e dentro de caixas de texto, especialmente porque esses dois trabalhos de Woolf não foram publicados em Língua Portuguesa. Também não é nossa proposta apresentar uma tradução.

$\mathrm{Na}$ passagem para esta tese também, não vamos adequar esses trechos selecionados aos padrões da norma culta em Língua Inglesa, a fim de manter sua singularidade. Portanto, optamos por transcrevê-los para esta tese exatamente como aparecem nos livros de Woolf. As passagens de The Hours aparecem como citações longas, recuadas da margem esquerda a seis centímetros (padrão que 
adotamos nessa tese para todas as citações), como as outras citações acadêmicas desta pesquisa. Em alguns exemplos de The Hours, das Cartas (1982) e dos Diários (1980), marcaremos algumas passagens em negrito para comentar em seguida. Apenas para conferência, incluímos em notas de rodapé, em alguns momentos que consideramos como necessários, trechos da tradução de The Hours feita por Beth Vieira (1999).

Nossa proposta inicial dentro deste capítulo é apresentar alguns trechos importantes de The Hours que evidenciam de forma mais clara as adaptações dos textos-fonte e a forma como foram colocados dentro desse romance. Agrupamos essas adaptações por temas, pois acreditamos que o autor procurou desenvolver suas personagens em The Hours confrontando-as a certo tema. Essa foi sua proposta principal ao adaptar a obra woolfiana, inferimos. 


\subsection{Das Cartas}

Afirmamos nesta tese que alguns trechos e temas das cartas presentes no último volume da série The Letters of Virginia Woolf vol. VI (1982), coleção editada por Nigel Nicolson ${ }^{12}$ e Joanne Trautmann, ${ }^{13}$ foram ora "adaptados" ou "apropriados" por Cunningham em The Hours, conforme os conceitos formulados por Sanders (2006).

Sabemos que os seis volumes da série completa - publicada originalmente entre 1975 e 1982 - reúnem as principais cartas escritas por Woolf entre os anos de 1888 (quando tinha apenas seis anos de idade) e 1941 (ano do seu falecimento, aos 59 anos de idade) para alguns de seus amigos, familiares e pessoas com quem manteve parceria profissional. Também vale ressaltar que em cada edição alguns temas relacionados à vida de Woolf naquele período são destacas. No volume VI, consultado por Cunningham quando da elaboração de The Hours, podemos destacar a temática de sua própria doença (e o agravamento desta), a finalização e edição de seu último romance, Betwen the acts (1941), e as cartas de suicídio.

Virginia Adelaide Woolf foi uma escritora inglesa que viveu de 1882 a 1941, tendo seu trabalho discutido no âmbito do modernismo inglês (século $X X$ ). Ela publicou romances, contos e ensaios críticos. Nos romances, inovou ao introduzir, como Joyce, os fluxos de consciência. Também explorou o lado psicológico de suas personagens. Seus temas são bem autobiográficos e alguns trazem nuances

\footnotetext{
${ }^{12}$ Nigel Nicolson (1917-2004), conforme consta em matéria do jornal britânico The Guardian (DE-LANOY, 2004), foi um editor britânico e também autor de várias obras. Nicolson era filho de Vita Sackville-West, apontada como uma das amantes de Virginia Woolf.

${ }_{13}$ De acordo com artigo da revista científica The Lancet (ORANSKY, 2007), Joanne Trautmann (1941-2007) foi uma editora americana e professora da Pennsylvania State University Medical School que, juntamente com Nigel Nicolson, editou os seis volumes das cartas de Woolf, publicados entre 1975 e 1980.
} 
históricas do período em que viveu: especialmente os acontecimentos relacionados à Primeira e a Segunda Grande Guerras.

O que mais chamou a atenção dos críticos literários em Woolf foi, sem dúvida, a profundidade de suas personagens. Acontecimentos simples do dia a dia são retratados, como em Mrs. Dalloway (1925), de maneira bastante reflexiva. Esse feito agradou a crítica literária modernista internacional. Pelo menos até 1941, ano de sua morte, Woolf foi bastante reconhecida como escritora, tendo recebido diversos elogios da crítica da época. Após algum tempo, especialmente nos anos 1970, a "crítica literária feminista" retomou os estudos woolfianos. Mais recentemente, também os Queer Studies discutem suas obras.

As edições de seus diários trazem inclusive correspondências de Woolf para prováveis amantes. Por exemplo: algumas são endereçadas a Vita Sackville-West, apontada pela pesquisadora Karyn Sproles (2006) como sua principal amante na obra Desiring Women: the partnership of Virginia Woolf and Vita Sackville-West. Convém ressaltar que, até o fechamento desta pesquisa em julho de 2014, não havia qualquer edição traduzida das cartas de Woolf publicada no Brasil. Não há uma coletânea sequer, como aconteceu com os diários em 1989, conforme veremos no próximo item. Os leitores brasileiros que, por qualquer motivo, não tenham acesso aos originais das cartas em inglês, precisam, dessa forma, aguardar. Talvez, a reescrita da obra de Woolf concretizada em/por "As Horas" (1999) ainda não tenha influenciado a descoberta dos editores/patronos brasileiros pelas cartas de Woolf, fazendo, assim, com que permaneçam inéditas em edição brasileira. 
Conforme dissemos, o volume VI, obra particularmente consultada por Cunningham quando da elaboração do romance The Hours, ${ }^{14}$ traz as correspondências escritas por Woolf nos últimos anos de sua vida (entre 1936 e 1941). Essas cartas aparecem adaptadas especialmente nos capítulos de The Hours intitulados Mrs. Woolf, que são organizados de forma alternada para contar a história da escritora sob a interpretação de Cunningham em dois momentos: o da escrita do romance Mrs. Dalloway (que ocorreu entre os anos 1920 e 1925) e dos dias que antecederam sua morte por suicídio, em 1941. Identificaremos essa proposta nos subitens "Suicídio, doença, Guerra e morte em The Hours" e "Suicídio, doença, Guerra e morte pelos Diários e Cartas de Woolf".

Nosso estudo demonstra ainda que Cunningham, a partir de sua leitura das cartas de Woolf, desenvolveu outros temas em The Hours que discutiremos em posterior subitem deste trabalho. Inicialmente, o que se vê é que Cunningham preocupou-se em criar um contexto para apresentar o conteúdo dessas correspondências, normalmente, um contexto de justificativa e exploração de temas segundo sua interpretação. Cunningham organiza os elementos que escolheu em sua pesquisa em torno dos romances, cartas, ensaios, biografias e diários de Woolf para criar uma narrativa de cunho pessoal, interpretativo, baseada em seu entendimento da obra woolfiana e também da vida particular da escritora.

Um ponto importante e, ao mesmo tempo, simples, que ressaltamos agora está relacionado a uma reflexão sobre a composição de uma carta: é escrita, em sua primeira intenção autoral, como forma de comunicação entre duas pessoas apenas. Tratando-a como gênero literário, temos então um gênero de fronteira, um texto que expressa algo entre o público e o privado. Isso porque a carta revela frequentemente

\footnotetext{
${ }^{14}$ Conforme ficha catalográfica.
} 
algo muito íntimo de seu autor, e o texto de Woolf prova essa intimidade pelas confissões que a autora faz em várias de suas cartas, além das críticas a escritores e editores, pontos esses jamais debatidos em seus contos ou romances. Temos ainda as marcas de oralidade, ausência de apóstrofos e uso de expressões mais coloquiais que podem ser conferidas através da leitura de alguns exemplos mostrados a seguir. Marcos Moraes (2007, p. 30), em importante estudo brasileiro sobre as cartas de escritores enquanto gênero literário, diz que elas podem funcionar:

\begin{abstract}
como 'arquivo da criação', espaço onde se encontram fixadas a gênese e as diversas etapas de elaboração de uma obra artística, desde 0 embrião do projeto até 0 debate sobre a recepção crítica favorecendo a sua eventual reelaboração. A carta, nesse sentido, ocupa o estatuto de crônica da obra de arte. A crítica genética, ao considerar a epistolografia um "canteiro de obras" ou um "ateliê", busca descortinar a trama da invenção, o desenho de um ideal estético, quando examina as faces dos processos da criação.
\end{abstract}

Dessa forma, é assim que investigamos The Hours: examinando seu processo de criação por Cunningham com base na leitura sobre as cartas de Woolf. Acreditamos que a influência das cartas está na gênese da ideia de The Hours e inferimos que o autor buscou a intimidade de Woolf para desenvolver seu próprio trabalho, comercializado editorialmente como um romance inédito, mas que, segundo nossa discussão, também é uma adaptação de diversos elementos da obra woolfiana.

O trabalho da pesquisadora brasileira Zenoi Santos (2009) reitera que as cartas, em um processo de investigação histórica ou antropológica, podem e devem ser utilizadas como fonte documental. O estudo organizado por Walnice Galvão e Nádia Goltlib (2009), pesquisadoras brasileiras, nos alerta inclusive para a escassez de pesquisas acadêmicas no Brasil e no exterior sobre as cartas de grandes 
escritores. Esse dado, sem dúvida, motivou nossa pesquisa e nos fez reler The Hours pensando na forte influência das cartas de Woolf dentro do processo criativo de Cunningham.

Também preferimos nos concentrar especialmente no processo de adaptação das cartas e diários de Woolf por Cunningham pensando inclusive no aspecto de uma tentativa de ineditismo desta tese. Sabemos que, apesar de já existirem trabalhos como os de Silva (2007) e de Sanders (2006) que tocam o nosso tema, esses se limitam a descrever as confluências entre o romance Mrs. Dalloway e The Hours, deixando em segundo plano a questão da adaptação das cartas e diários. Decidimos, então, preencher essa lacuna, além do viés de oferecer um panorama das traduções de obras de Woolf no Brasil e mostrar o processo de reescrita de sua obra no nosso país.

Quanto às cartas e seu papel dentro dos diversos sistemas literários do mundo, ocorre que, internacionalmente, a abordagem da pesquisa acadêmica até os anos 2010 sobre esse tema parecia mais voltada ao estudo dos chamados romances epistolares. Os romances epistolares são obras de ficção que agregam cartas como capítulos ou uma narrativa de ficção contada através de cartas. 0 trabalho de Janet Altman (1982) discute bem essa questão e também o que ele chama de "epistolarity", o uso formal das cartas para criar significados e também uma tendência de escrever romances epistolares observada por essa pesquisadora entre alguns escritores a partir dos anos 1970 do século XX. Ressalta ainda, dentro desse trabalho, como as cartas estão cada vez mais presentes na literatura mundial e como o público da contemporaneidade se identifica com o gênero. Esse fato ocorre, segundo inferimos, porque a carta enquanto gênero literário de ficção ou não ficção sugere uma ideia de exposição de confissões e de textos privados que é 
bastante apreciada pelo leitor dos anos 2010. Esse leitor elegeu gêneros de fronteira, como os diários e as cartas de não ficção de escritores, por exemplo, como alguns de seus prediletos. Talvez isso ocorra porque as editoras perceberam que esses textos dialogam com os leitores de forma mais particular, especialmente porque mostram a intimidade desses escritores, fato que aguça a curiosidade. Os diários e as cartas de não ficção incorporam características da narrativa romântica clássica que os tornam muito próximos a ela.

Observamos que as cartas de escritores como Woolf nos remetem a uma outra categoria literária diferente dos romances epistolares: são as cartas privadas ou "familiares", conforme classifica William Todd III (1999) em estudo voltado a esse tema. Nesse caso, não falamos de uma carta elaborada como obra literária de ficção. Tratamos, sim, de cartas reais, registros de conversas entre duas pessoas que, em princípio, jamais foram pensadas para publicação. A pesquisadora alemã Marianne Alenius (2012), em trabalho sobre o tema das cartas familiares, chega mesmo a afirmar que a escrita de cartas sempre foi algo apreciado pelas mulheres desde a antiguidade greco-romana:

The private letter as semi-public aesthetic-literary genre was not the invention of the eighteenth century. In Europe, this kind of letter was current in Greco-Roman Antiquity; the genre was highly-developed in the Roman period, and the Renaissance considered Cicero and Pliny to be its finest representatives. The naturalness of their smooth sentences written in colloquial language was imitated with mixed results.

Esse gosto tem certamente relação direta com o fato de que nessa época, de forma geral, quase não era permitido à mulher expressar-se artisticamente. Assim, ao longo dos séculos, esse impedimento foi gradativamente infuenciando as mulheres a se expressarem através da escrita. Essas correspondências - bem como 
os diários - funcionavam como uma libertação pela escrita. Mesmo no caso de mulheres escritoras, para além da produção de romances, contos, poemas, trocar correspondências costumeiramente reveladoras com amigos, familiares e amantes também permaneceu como prática comum na história da literatura.

Nesse trabalho, em que trata mais diretamente das cartas da escritora francesa Madame de Sévigné (1626-1696), Alenius (2012) reitera o aspecto levantando por Todd III (1999) do papel autobiográfico desse gênero. Isso pode ser facilmente entendido no caso de escritoras femininas que, conforme já dissemos, encontravam pouco espaço para se expressarem. Com Woolf, não foi diferente. Diversos aspectos de sua personalidade são facilmente percebidos através de uma leitura atenta sobre suas cartas e diários. Um desses aspectos é a possível relação amorosa que mantinha com Vita Sackville-West.

A relação com Vita Sackville-West revela dois vieses para discussão: o fato de Woolf ter amantes e, o fato de ter atração por pessoas do mesmo sexo. Esses dois temas obviamente foram trabalhados por Woolf em seus romances. Contudo, em nenhum deles a escritora se define como biografada.

Aliás, para mostrar que Woolf também passeou, em termos de criação literária, pelo gênero da biografia, vale informar que, além dos romances, contos e ensaios, ela intitulou três de seus trabalhos dessa forma, sendo eles Orlando: a biography (1928), dedicado a Vita Sackville-West, Flush: a biography (1933), em homenagem a um cão que teria pertencido a poeta vitoriana Elizabeth Barrett Browning, ${ }^{15}$ e Roger Fry, a biography (1940), em homenagem a esse amigo e crítico

\footnotetext{
${ }^{15}$ Elizabeth Barrett Browning (1806-1861) foi uma poeta inglesa da época vitoriana (século XIX). Seus trabalhos eram muito apreciados por Woolf.
} 
literário. ${ }^{16}$ Mesmo assim, esses trabalhos são categorizados pela crítica literária também em outras vertentes por mesclarem elementos do romance com dados reais (não ficção).

Woolf nunca pretendeu se autodefinir nos trabalhos que criou para serem publicados. Também não a agradava que a crítica literária a rotulasse, o que deixou claro em alguns trechos dos diários e cartas. De acordo com esses escritos, ela sempre achou que sua vida não daria um romance e, também, que seu prazer era escrever livremente, mas não sobre sua vida privada.

Ainda assim, a partir do momento em que, por exemplo, a família de um escritor reúne e edita suas cartas particulares (no geral, postumamente), essas cartas cumprem, no contexto da literatura, o mesmo papel dos romances epistolares. Em outras palavras, elas são tratadas como obras literárias pelo leitor, com o diferencial de que despertam grande curiosidade pelo fato de serem, nesse caso, cartas íntimas e, em princípio, legítimas, autênticas e verossímeis.

A ideia de uma realidade não imaginada pelo escritor, mas, sim, vivida por ele, atrai o público. Recordamos o tema das histórias "baseadas em fatos reais" muito frequente em filmes nacionais e internacionais, que têm o mesmo intuito: chamar a atenção do público através da ideia de realidade e da verossimilhança. Essa mensagem nada subliminar costuma causar frisson em grande parte dos espectadores, que ficam mais curiosos e ansiosos para ver o filme. A nosso ver, isso também pode estar ocorrendo na literatura mundial.

\footnotetext{
${ }^{16}$ Roger Fry (1866-1934) foi um artista, crítico de arte e membro do Bloomsbury Group que conviveu de perto com Virginia Woolf. Ela admirava seu trabalho e inteligência.
} 
Talvez, diante do crescente interesse do público leitor pelo mundo das cartas de não ficção é que percebemos, a partir dos anos 1980 do século XX, um interesse particular dos patronos editoriais do mundo todo pela publicação das cartas familiares de escritores (canônicos) e um considerável aumento de publicações desse tipo disponíveis nas livrarias. Possivelmente, esse interesse é direcionado para aumentar para além dos intelectuais, acadêmicos e demais pessoas que tiveram acesso à sua obra o público leitor desses escritores na atualidade.

Sabemos que, uma vez publicadas, as cartas de escritores de realidades tão distintas das do público contemporâneo humanizam sua imagem, aproximando os dois lados: público novo e escritores canônicos. As cartas privadas de grandes escritores, como as de Woolf, mostram seu lado de escritor comum, e essa veracidade a respeito de um grande autor e do cenário em que viveu é muito apreciada pelo público leitor. Podemos confirmar essa informação através do que percebemos ser um aumento do número de obras literárias desse tipo publicadas nos últimos vinte anos. Citamos e recomendamos como exemplo para reforçar nosso argumento a recente obra Letters do escritor americano e Nobel de literatura Saul Bellow, editada por Benjamim Taylor (2010), na qual algumas das cartas trocadas entre Below e outras personalidades famosas, incluindo escritores como William Faulkner, ${ }^{17}$ são organizadas de forma bastante alusiva a revelar essa cena de intimidade do escritor. O mesmo caso se apresenta para o livro $A$ life in letters, com algumas das principais cartas do escritor britânico George Orwell (2010). ${ }^{18}$

As cartas de um escritor podem ainda refratar (LEFEVERE, 1982b), por exemplo, obras escolhidas por ele para leitura e dados de seus romances de ficção.

\footnotetext{
17 FAULKNER, William. The Sound and the fury. Londres: Jonathan Cape, 1929.

${ }^{18}$ ORWELL, George. A life in letters. Londres: Harvill Secker, 2010.
} 
As adaptações literárias atuam da mesma forma, podendo levar o leitor a conhecer a obra de ficção desse escritor canônico.

Porém, não acreditamos que essa seja a única possibilidade de interação. Para começar a ler as obras de ficção de determinado escritor canônico não é necessário começar via adaptações, cartas e diários para, só depois, ler seus romances. Acreditamos que esse acesso é sempre muito circunstancial. Lefevere (1982b, p. 248) confirma essa ideia quando diz

\begin{abstract}
A systems approach does not try to influence the evolution of a given literary system, the way critical refractions and many translations avowedly written in the service of a certain poetics tend to do. It does not try to influence the reader's concretization of a given text in a certain direction. Instead, it aims at giving the reader the most complete set of materials that can help him or her in the concretization of the text, a set of materials he or she is free to accept or reject.
\end{abstract}

Percebemos, assim, que não são os sistemas literários mundiais (ZOHAR, 2000) em si que direcionam o gosto dos leitores pela obra de determinado escritor. isso é feito, na verdade, pelas traduções e refrações críticas. Podemos incluir nesse grupo também as adaptações literárias. Lefevere (1982b) destaca que, nesse caso, são as ideologias particulares dos adaptadores, tradutores e resenhistas - inseridas nos textos por eles trabalhados - que influenciam o leitor comum e também os professional readers a conhecer a obra de ficção de determinado escritor. Essas refrações fazem toda a diferença na formação de um público leitor de determinado autor.

Sobre os escritores canônicos há sempre uma considerável quantidade de informações publicadas que se relacionam às suas obras de ficção. Àquelas que são feitas por estudiosos, biógrafos e especialistas (como os prefácios das obras e resenhas críticas), chamamos de refrações críticas. Textos de não ficção, como 
cartas e diários de um escritor, também são refrações porque, de alguma forma, remetem à obra principal desse autor. Assim, as cartas são refrações que se incluem nessa variedade editorial de materiais que o leitor possa interessar-se pela leitura de suas obras de ficção.

O fato é que as cartas de escritores, publicadas também como obra literária, revelam um texto muito particular. Elas sem dúvida podem fazer com que o leitor contemporâneo estabeleça relações importantes com os romances de determinado escritor.

\subsection{Dos Diários}

Os diários de Woolf foram publicados pela primeira vez na Inglaterra entre o final dos anos 1970 e o começo dos anos 1980 em série de cinco volumes editados por Anne Olivier Bell ${ }^{19}$ (1916-?) e Andrew McNeillie ${ }^{20}$ (1946-?). Através da matéria publicada no periódico inglês The Guardian pelo jornalista Charles Smith (2013), descobrimos que o trabalho de pesquisa e também de transcrição, seleção de passagens e escrita de notas de rodapé - levou ao todo vinte e cinco anos para ser concluído.

Apesar dessa quantidade grande de edições originais no Brasil, foi publicada apenas uma em 1989 pela editora Companhia das Letras. O trabalho de seleção e tradução das passagens dos diários para o português do Brasil ficou a cargo do

\footnotetext{
19 Anne foi casada com Clive Bell (sobrinho de Woolf) e está atualmente com 97 anos. Foi condecorada com dois prêmios honorários pela publicação dos diários de Woolf e também convidada a tornar-se membro da Royal Society of Literature (MONUMENTS MEN FOUNDATION, 2014).

${ }_{20}$ Poeta britânico e, atualmente, editor da Oxford University Press aos 67 anos (LITERATURE WALES, 2014).
} 
tradutor José Antonio Arantes. ${ }^{21}$ Nesse caso, Arantes fez um apanhado dos momentos que considerou mais relevantes sobre a vida de Woolf e reuniu tudo isso em um único volume. ${ }^{22}$ A proposta é bem diferente da publicação original, que divide as passagens em grupos de cinco anos, perfazendo a vida da escritora desde 1915 até 1941, ano em que faleceu.

Os diários de Woolf, bem como as cartas, também são carregados de relatos sobre sua vida particular. Pensando outra vez na questão da proposta autoral de um texto como o diário, ao trabalhá-lo como gênero literário, concluímos que é possível perceber uma intimidade maior ainda do que aquela percebida na leitura de suas cartas. Dizemos isso porque, durante o processo de escrita em um diário, seu autor, em princípio, não prevê leitores. Trata-se de um texto em que a dinâmica é a do livre registro de memórias acumuladas ao longo de um dia. Seu autor pretende, em princípio, apenas arquivá-las para poder recordá-las em algum momento futuro. A pesquisa de Bruce Merry (1979, p. 3) confirma nosso entendimento quando compara o diário a outros gêneros literários. Esse trabalho relata ainda que, quanto a fornecer ao leitor características da época e dos hábitos de um povo, o diário se iguala a outros gêneros literários, porém se destaca por um aspecto: ressalta as características de opiniões e relatos mais íntimos do escritor-autor sobre esses itens. Ele acrescenta:

We might be tempted to say that all other literary forms are bound to the age and habits of the period which produced them, but the diary stands outside these constraints; the diary is an intimate journal, a personal dialogue between the writer and his private persona, in which anything can be discussed outside the push and pull of editorial fashion.

\footnotetext{
${ }^{21}$ José Antônio Arantes é tradutor em atividade da editora Companhia das Letras (COMPANHIA DAS LETRAS, 2014). Foi elogiado pelo jornalista, poeta e crítico de literatura Ivo Barroso pela tradução de poemas do irlandês Seamus Heaney (BARROSO, 1998) e já traduziu diversos autores ingleses.

${ }^{22}$ Os Diários de Virginia Woolf. Trad. José Antônio Arantes. São Paulo: Companhia das Letras, 1989.
} 
Normalmente, os diários físicos (o bloco de textos de memórias) são guardados com cuidado por seus autores por conta das revelações feitas neles e para preservar as pessoas citadas. O objetivo primeiro, reforçamos, é apenas recordar. Woolf registrava suas memórias quase que diariamente. Os assuntos, registrados, por vezes, de maneira longa, consistiam principalmente em afazeres profissionais e domésticos, suas experiências de leitura e edição das obras de outros escritores, suas impressões sobre outras pessoas com quem convivia, as festas que frequentava, sua saúde (ou a falta dela), sua família e amigos.

Para esta pesquisa, buscamos no volume II dos Diários da escritora (1980) alguns exemplos que nos remetessem ao processo de criação de Mrs. Dalloway, romance que elaborou entre 1920 e 1924, por estarem presentes nesse volume as suas angústias em torno da elaboração da obra em questão. Também estão presentes ali outros temas que são desenvolvidos/adaptados/apropriados em The Hours por Cunningham ao logo dos capítulos Mrs. Woolf.

Dessa forma, novamente afirmamos que os capítulos de The Hours intitulados Mrs. Woolf são aqueles em que as adaptações dos Diários (1980) e Cartas (1982) nos parecem mais evidentes. Isso ocorre porque essas edições narram o dia a dia de Virginia Woolf especialmente durante o processo de criação do romance Mrs. Dalloway (em seus medos, angústias e impressões sobre si mesma), suas reflexões sobre o ato de escrever, sobre a sociedade, os criados, os amigos, etc.

A seguir, apresentamos pelo menos quatro depoimentos de Woolf retirados dos Diários (1980) relacionados ao processo de criação de Mrs. Dalloway, principal afazer de Woolf no romance The Hours. 


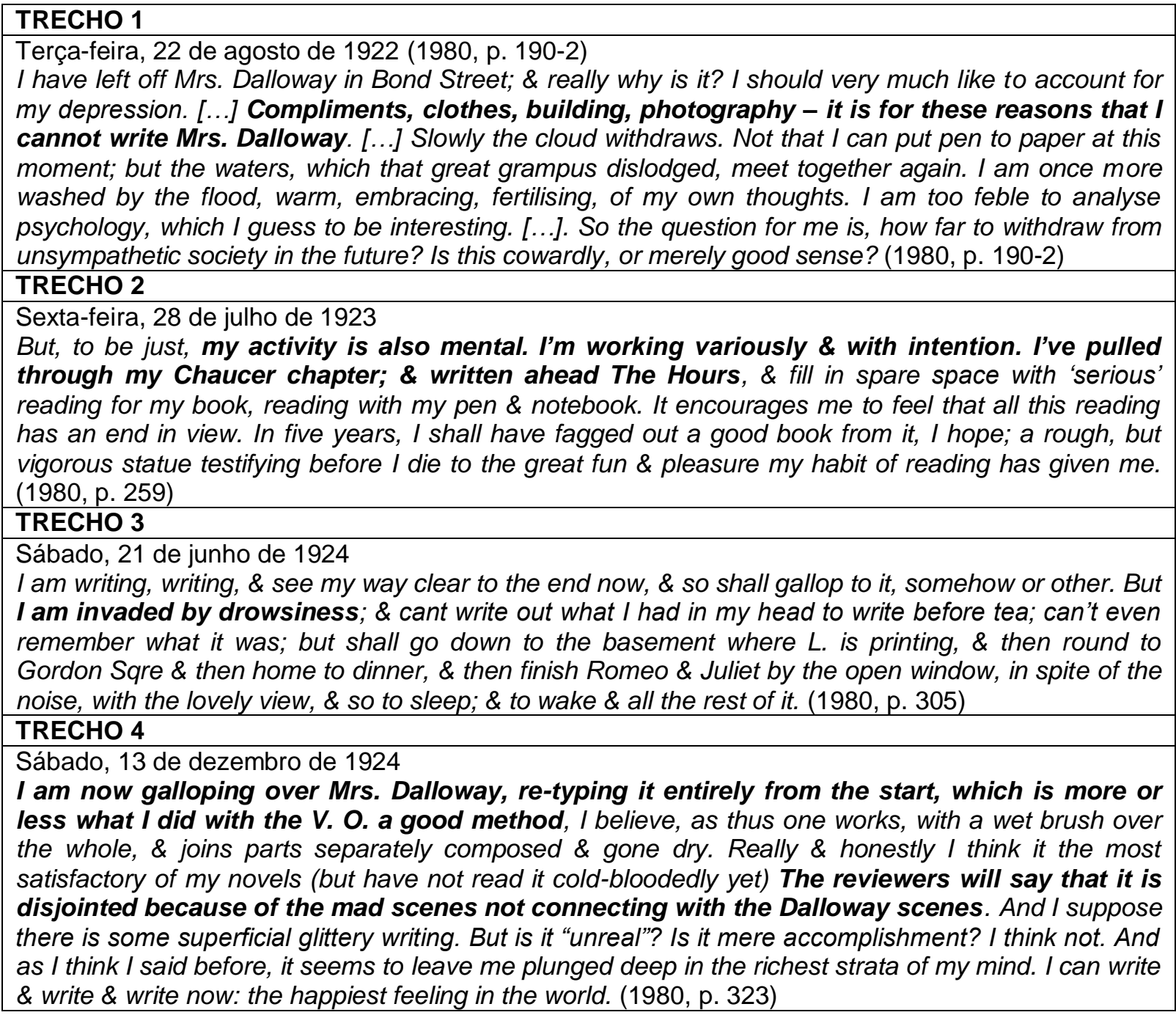

Nessas passagens, Woolf fala de aspectos que atrapalham a escrita do romance Mrs. Dalloway, como os afazeres do dia a dia e sua mente inquieta (TRECHO 1), o sono e a solidão (TRECHO 3), bem como alguns momentos de estagnação na criação desse trabalho. A autora também descreve o proceso intuitivo de criação (TRECHO 2) e a revisão final do livro (TRECHO 4). Sem dúvida, esse trabalho impulsionou Woolf a continuar escrevendo e, vê-lo pronto, Ihe trouxe grande prazer.

Essa edição pesquisada dos diários (1980) obedece àquela única citada pelo autor Michael Cunningham na ficha catalográfica de The Hours, apesar de seu 
depoimento em a note on sources (p. 229-30) revelar que esse autor também pesquisou biografias diversas, além de artigos e depoimentos sobre a escritora inglesa. Sendo assim, essa edição (1980) nos parece a mais importante para a criação do romance The Hours em sua versão final e a que foi, diante das outras, mais diretamente adaptada e/ou apropriada.

Recapitulando, o principal tema da edição pesquisada dos diários de Woolf é o processo de criação do romance Mrs. Dalloway, publicado em 1925, porém escritos nos quatro anos anteriores. Descobrimos, através de pesquisa em textos ficcionais e não ficcionais sobre/de Woolf, que o principal casal de personagens desse romance, Clarissa Dalloway e Richard Dalloway, já haviam sido apresentados ao leitor em The Voyage Out (1915), mas apenas como personagens secundários.

Depois, verificamos que, inicialmente, Woolf pretendia escrever apenas um conto sobre a personagem Clarissa. Assim, Woolf criou Mrs. Dalloway in Bond Street, provavelmente escrito em 1922, mas publicado apenas em 1923 (LEVY, 2010, p. 08). A autora primeiramente ofereceu o texto à revista britânica The Criterion (publicação que existiu de 1922 a 1939, com tiragem quadrimestral), criada e editada pelo amigo e reconhecido escritor americano naturalizado britânico, T. S. Eliot (1888-1965), para possível publicação. Eliot recusou o texto, que foi publicado somente no ano seguinte pela também conceituada The Dial, revista norteamericana responsável principalmente pela publicação de trabalhos de escritores transcedentalistas dos EUA entre 1840 e 1929. Essas informações, presentes em prefácios de várias edições traduzidas para o português - e também em edições em inglês de Mrs. Dalloway -, são ainda reforçadas em notas de rodapé pelos editores Bell e McNeillie na edição pesquisada dos diários (1980). 
Nesse conto, Clarissa era bastante dependente e frívola, sendo que Richard era sofisticado e dominador. Ambos foram mantidos dessa forma pela autora também em Mrs. Dalloway. Outro detalhe é que a provável inspiração à personagem Clarissa Dalloway vem de uma amiga da vida real de Woolf, Katherine Maxse, a quem Woolf chamava de Kitty.

Empolgada com a personagem Clarissa Dalloway (o que evidencia sua preferência pelas personagens femininas), Woolf decidiu que o conto seria ampliado em um livro (1980, p. 207), conforme podemos conferir em anotação de 14 de outubro de 1922. Ela comenta ainda a ideia da personagem Septimus Smith.

I want to be writing unobserved. Mrs. Dalloway has branched into a book; \& I adumbrate here a study of insanity \& suicide: the world seen by the sane \& the insane side by side - something like that. Septimus Smith? Is that a good name? - \& to be more close to the fact than Jacob: but I think Jacob was a necessary step, for me, in working free.

\subsection{Suicídio, doença, Guerra e morte em The Hours}

Logo no início do romance The Hours, temos um prólogo que é, na verdade, um pano de fundo criado por Cunningham para a apresentação de uma das cartas de suicídio deixadas por Woolf para seu esposo Leonard. No prólogo, também encontramos logo de início outros temas que serão abordados por Cunningham ao longo do romance: a insegurança de Woolf como escritora (o quanto ela, nesse momento da vida, não se julga boa nessa tarefa) e a referência à doença mental.

Uma vez que Cunningham escolheu abrir The Hours com uma narração tão dramática acerca do episódio do suicídio de Woolf, dá a ideia de que ele desejava contar essa história antes de qualquer outra. É como se quisesse mostrar ao leitor que Woolf já desenvolvia a ideia do suicídio há tempos e que sua atual condição mental, aliada a outros fatores, só apressou essa decisão. 
Começaremos apresentando um trecho desse prólogo em The Hours para que seja analisada a forma como Cunningham introduz ao leitor a escritora Virginia Woolf como personagem. O prólogo abre o romance e é logo sequenciado pelo primeiro capítulo intitulado Mrs. Woolf. Dessa forma, o autor mostra ao leitor dois momentos distantes da vida da escritora: o dia do seu suicídio (em um subúrbio de Londres, 1941), e alguns acontecimentos do ano 1923, época em que escrevia o romance Mrs. Dalloway.

Através da leitura do prólogo, constatamos que o primeiro passo de Cunningham na elaboração de The Hours foi o de tentar "adaptar", conforme conceito de Sanders (2006), o final trágico da vida de Woolf. Para tanto, colheu informações principalmente das últimas páginas de The Letters of Virginia Woolf vol. VI (1982) - mais precisamente, das chamadas "cartas de suicídio" - reproduzindo depois uma delas no início de The Hours. Eis o prólogo de The Hours (1998, p. 3-4) que cria o contexto para a apresentação de uma das cartas de suicídio de Woolf:

\begin{abstract}
She hurries from the house, wearing a coat too heavy for the weather. It is 1941. Another war has begun. She has left a note for Leonard, and another for Vanessa. She walks purposefully toward the river, certain of what she'll do, but even now she is almost distracted by the sight of the downs, the church, and a scattering of sheep, incandescent, tined with a faint hint of sulfur, grazing under a darkening sky. She pauses, watching the sheep and the sky, then walks on. The voices murmur behind her; bombers drone in the sky, though she looks for the planes and can't see them. She walks past one of the farm workers (is his name John?), a robust, small-headed man wearing a potato-colored vest, cleaning the ditch that runs through the osier bed. He looks up at her, nods, looks down again into the brown water. As she passes him on her way to the river she thinks of how successful he is, how fortunate, to be cleaning a ditch in an osier bed. She herself has failed. She is not a writer at all, really; she is merely a gifted eccentric. Patches of sky shine in puddles left over from last night's rain. Her shoes sink slightly into the soft earth. She has failed, and now the voices are back, muttering indistinctly just beyond the range of her vision, behind her, here, no, turn and they've gone somewhere else [...]. (grifos nossos) ${ }^{23}$
\end{abstract}

\footnotetext{
${ }^{23}$ Ela sai de casa apressada, vestida com um casaco pesado demais para a época do ano. Estamos em 1941. Há uma outra guerra em andamento. Deixou um bilhete para Leonard, outro para Vanessa. Caminha decidida em direção ao rio, certa daquilo que fará, mas mesmo assim, um tanto distraída, observando as colinas, a igreja e um grupo de carneiros, incandescentes, matizados por um vago tom cor de enxofre, que pastam sobre um céu enfarruscado. Para, vendo os carneiros e o céu, depois retoma o caminho. As vozes murmuram atrás dela; bombardeiros zumbem no alto, ainda que procure
} 
Sobre os trechos em negrito do prólogo de The Hours apresentados acima, em primeiro lugar, constatamos uma forte referência feita pelo narrador Cunningham à Guerra em curso, qual seja a Segunda Grande Guerra, que havia começado dois anos antes. O narrador cita os aviões que lançavam bombas (bombers), e a personagem descrita por Cunningham apenas pelo pronome she é Virginia Woolf. Dessa forma, Cunningham descreve as emoções, pessoas e acontecimentos que Woolf provavelmente encontrou no trajeto entre sua casa e o rio, onde se afogou e morreu. Embora compenetrada em seu pensamento suicida, Woolf faz constantes referências ao bombardeio e o quanto a situação de guerra a incomodava em termos de solidariedade humana com os povos envolvidos nesse triste e, ao mesmo tempo, importante evento da história.

Logo após o prólogo, em outro trecho, Cunningham descreve de maneira metafórica o corpo de Woolf já sem vida, preso ao fundo do mesmo rio, ao mesmo tempo que descreve um garotinho que passa sobre uma ponte com sua mãe e atira um galho nesse memo rio. Esse garoto quer tanto acompanhar visualmente o galho seguindo pela correnteza quanto que sua mãe o erga nos braços para ver os soldados que passariam por ali. A sugestão de Cunningham (narrador) é que, nesse contexto, o leitor imagine o garotinho, sua mãe, os soldados, a ponte, o rio e todo compondo o triste cenário da morte de Woolf. Esse contexto é advindo da leitura das últimas cartas de Woolf.

os aviões e não os veja. Passa por um dos empregados da fazenda (seria John, o seu nome?), um homem robusto, de cabeça pequena, que usa uma camisa cor de batata e limpa um rego entre os chorões. Ele ergue os olhos para ela, faz um gesto com a cabeça, baixa a vista de novo para a água pardacenta. Ao cruzar com ele, a caminho do rio, pensa em como é bem sucedido, no quanto é feliz ao limpar um rego que corre entre chorões. Ela mesma fracassou. Não é escritora coisa nenhuma, não é de verdade; é apenas uma excêntrica bem dotada. Pedaços de céu brilham nas poças de água deixadas pela chuva da noite anterior. Seus sapatos afundam ligeiramente na terra fofa. Ela fracassou, e agora as vozes voltaram, resmungando de modo indistinto bem atrás do seu campo de visão, atrás dela, aqui, não, basta virar que elas somem e vão para um outro canto. (1999, p. 9). 
Na sequência do romance, o leitor de The Hours se depara com um texto compilado por Cunningham a partir das cartas de suicídio, ${ }^{24}$ deixadas por Woolf pouco antes de sua morte (1998, p. 6-7):

Leonard goes upstairs to the sitting room to listen to the news. He finds a blue envelope, addressed to him, on the table. Inside is a letter.

Dearest,

I feel certain that I am going mad again: I feel we cant go through another of these terrible times. And I shant recover this time. I begin to hear voices, and cant concentrate. So I am doing what seems the best thing to do. You have given me the greatest possible happiness. You have been in every way all that anyone could be. I dont think two people could have been happier till this terrible disease came. I cant fight it any longer, I know that I am spoiling your life, that without me you could work. And you will I know.

You see I cant even write this properly. I cant read. What I want to say is that I owe all the happiness of my life to you. You have been entirely patient with me \& incredibly good. I want to say that everybody knows it. If anybody could have saved me it would have been you. Everything has gone from me but the certainty of your goodness. I cant go on spoiling your life any longer. I dont think two people could have been happier than we have been.

V.

Leonard races from the room, runs downstairs. He says to the maid, "I think something happened to Mrs. Woolf. I think she may have tried to kill herself. Which way did she go? Did you see her leave the house?"

The maid, panicked, begins to cry. Leonard rushes out and goes to the river, past the church and the sheep, past the osier bed. At the riverbank he finds no one but a man in red jacket, fishing. (grifos nossos) ${ }^{25}$

\footnotetext{
${ }^{24}$ Tradução das mesmas expressões usadas no livro The Letters of Virginia Woolf, v. 6, qual sejam "the last letters" ou "suicide letters".

${ }^{25}$ Leonard sobe até a sala de estar para ouvir o noticiário. Encontra um envelope azul, endereçado a ele, sobre a mesa. Dentro, há uma carta.
} 
O texto acima foi "adaptado" a partir da primeira carta - dentre as chamadas cartas de suicídio - direcionada para Leonard Woolf, esposo da escritora, de acordo com a edição The Letters of Virginia Woolf (1982, p. 481). Nesse caso, Cunningham transcreveu o texto integral, provavelmente escrito em 18 de março de 1941 na Monk's House (Sussex, Inglaterra). Nesse mesmo dia, ela tentou o suicídio por afogamento, mas sem sucesso. Porém, no dia 28 daquele mesmo mês, ela saiu de casa rumo ao rio Ouse, encheu os bolsos de pedras e se atirou na água, dando fim à própria vida. Cunningham conta toda essa história em The Hours.

Essa carta a Leonard, uma segunda enviada ao editor John Lehmann ${ }^{26}$ e uma terceira endereçada à irmã, Vanessa Bell, fazem parte do grupo das chamadas "últimas cartas" de Woolf, todas escritas na famosa Monk's House, que fica no condado de Sussex, na Inglaterra. Woolf adorava Londres, mas mudou-se para um lugar mais tranquilo por motivos diversos (sendo a Guerra o principal deles). Isso aconteceu pouco antes de sua morte.

Tenho certeza de que estou ficando louca outra vez: sinto que não podemos passar por mais uma dessas temporadas terríveis. E desta vez eu não vou me recuperar. Começo a ouvir vozes e não consigo me concentrar. Por isso estou fazendo o que parece ser o melhor a fazer. Você me deu toda a felicidade que eu poderia ter. Você tem sido, sob todos os aspectos, tudo o que alguém podia ser. Não creio que pudesse haver no mundo duas pessoas mais felizes, até que veio essa doença terrível. Não posso mais combatê-la, sei que estou estragando sua vida, que sem mim você poderia trabalhar. E vai, eu sei. Você vê que nem estou conseguindo escrever isso direito. Eu não consigo ler. O que eu quero dizer é que devo toda a felicidade que tive na vida a você. Você foi imensamente paciente comigo e tremendamente bom. Eu quero dizer isso - e todo mundo sabe. Se alguém pudesse ter me salvado, esse alguém teria sido você. Tudo o que eu tinha se foi, exceto a certeza de sua bondade. Eu não posso continuar estragando sua vida. Não creio que duas pessoas poderiam ter sido mais felizes do que nós fomos.

\section{V.}

Leonard sai às pressas da sala, desce as escadas. Diz para a empregada: "Acho que aconteceu alguma coisa com a senhora Woolf. Receio que ela possa ter tentado se matar. Em que direção ela foi? Você a viu saindo de casa?"

A empregada, em pânico, começa a chorar. Leonard sai correndo e vai para o rio, passando pela igreja, pelas ovelhas, pelos chorões. Na margem, não encontra ninguém, exceto um homem de paletó vermelho, pescando (1999, p. 11-12).

${ }^{26}$ Segundo Willis (1992), nos anos 1930 John Lehmann (1907-1987) trabalhou para Virginia e Leonard Woolf como editor da Hogarth Press, fundada em 1917, e era amigo pessoal do casal. Escreveu uma das biografias de maior referência sobre Virginia Woolf (LEHMANN, 1989). 
Em suma: todas essas últimas cartas apresentam trechos em que a intenção suicida de Woolf se mostra bastante clara e o texto é marcado pelo tom de despedida. Nelas, Woolf ressalta vários aspectos de sua vida nessa carta: seu amor e gratidão por Leonard ("You have been in every way all that anyone could be"), a impossibilidade de recuperação da doença ("And I shant recover this time") e a frustração por não conseguir mais escrever, sua grande paixão ("You see / cant even write this properly").

A escolha dessa carta a Leonard, "adaptada" por Cunningham, não foi aleatória, visto que é a principal carta de suicídio deixada por Woolf (adiante, mostraremos também a carta à Vanessa Bell). Assim, funciona como um convite para que o leitor prossiga com a leitura do romance. Também funciona como um momento de apropriação (SANDERS, 2006) em que Cunningham recria a situação de morte da escritora para o público dos anos 2010 como se quisesse dar sua versão particular em torno desse acontecimento. Ao trazer Woolf para ser personagem de The Hours (e, logo na primeira página desse romance, descrever a cena do seu suicídio) Cunningham reelabora a morte da escritora como se quisesse torná-la uma heroína. O impacto que o suicídio de Woolf causa no leitor comum poderá fazer com que prossiga na leitura do romance e tente descobrir o contexto para aquele acontecimento tão trágico.

Na sequência, e logo após a apresentação do texto da carta de suicídio de Woolf, Cunningham narra o momento em que Leonard encontra essa carta e sai desesperado atrás da esposa ("Leonard rushes out and goes to the river, past the church and the sheep, past the osier bed", p. 7). A leitura comove o leitor e o impulsiona às próximas páginas. Outras cartas serão citadas ao longo da tese, pois também serviram como fonte de informação para Cunningham elaborar sua 
narração sobre os instantes finais da vida da escritora inglesa, narrados no prólogo apresentado.

Em The Hours, há ainda referências ao pensamento suicida com outra personagem: Laura Brown. Após citar uma passagem de Mrs. Dalloway, o narrador/adaptador Cunningham descreve o pensamento de Laura Brown da seguinte forma (1998, p. 151):

It is possible to die. Laura thinks, suddenly, of how she - how anyone - can make a choice like that. It is a reckless, vertiginous thought, slightly disembodied - it announces itself inside her head, faintly but distinctly, like a voice crackling from a distant radio station. She could decide to die. It is an abstract, shimmering notion, not particularly morbid. Hotel rooms are where people do things like that, aren't they?

Nesse caso, Cunningham preferiu tomar um rumo diferente daquele que tomou a trajetória real da escritora inglesa Virginia Woolf. Ao mesmo tempo em que percebemos na personagem Laura Brown um grande reflexo de Woolf e também da própria Mrs. Dalloway em termos de personalidade, acreditamos que a desistência do suicídio de Brown nos alerta para a intenção do adaptador de querer mostrar que há sempre uma possibilidade a ser tomada na vida, ao menos nesse momento da narrativa. Assim, Brown, apesar de fã assídua dos romances e biografias de Woolf, não se deixou influenciar por completo. Ela conhecia o final trágico de Woolf, mas seu desejo de libertação não passava por dar cabo à própria vida, concluiu a personagem.

Brown, segundo Cunningham, descobre que pôr fim à própria vida, algo aparentemente complexo, pode ser algo simples. Ela decide se testar, mas fica apenas na imaginação de como teria sido a morte de Woolf e como teria sido a sua própria, caso tivesse levado essa ideia até o fim. Ela deixa o filho Richie com uma 
babá, vai para um hotel, se tranca em um quarto, pensa bastante e acaba desistindo. Por último, declara ao leitor que tudo é uma questão de escolha, escolhendo em seguida a fuga e a vida.

Ainda assim, Cunningham não se afasta dessa ideia. O romance começa com o suicídio da própria Woolf, segue a com a tentativa de Brown, continua com a descrição do momento em que Woolf escreve o suicídio da personagem Septimus Smith em Mrs. Dalloway e termina com o de Richard.

Na passagem que apresentaremos, a personagem Clarissa Vaughan vai ao apartamento de Richard para ajudá-lo a se preparar para a festa que dará em seu apartamento como homenagem à premiação que ele recebeu pelo romance publicado. Encontrando-o atordoado e sentado à janela do apartamento prestes a se deixar cair (talvez por ter tomado vários medicamentos), Clarissa inicia uma conversa na tentativa de convencê-lo a desistir desse ato. Richard então relembra os bons momentos que os dois tiveram juntos, enquanto Vaughan implora para que ele não faça o que visualmente está prestes a fazer.

Durante toda a cena, é possível perceber que a decisão de Richard está tomada. O trecho apresentado mostra o final do encontro, no momento em que Richard se despede, citando ainda uma frase da principal carta de suicídio de Woolf, a mesma apresentada no início do romance (1998, p. 200): 
Richard smiles. He shakes his head. He says, "I don't think two people could have been happier than we've been."

He inches forward, slides gently off the sill, and falls.

Clarissa screams, "No-"

He seems so certain, so serene, that she briefly imagines it hasn't happened at all. She reaches the window in time to see Richard still in flight, his robe billowing, and it seems even now as if it might be a minor accident, something reparable.

Richard se atira do quinto andar e morre. A sequência da cena mostra Clarissa descendo apressada e pensando nele, no quanto o amava, no quanto vai sofrer com aquela perda e com a sensação de encontrá-lo morto. Podemos perceber nas personagens Woolf e Richard uma combinação percebida por Cunningham: depressão e suicídio. Cunningham se apropria da mesma temática aplicada por Woolf no romance Mrs. Dalloway nos anos 20: criar uma personagem deprimida e que comete suicídio - nesse caso, Septimus Smith. Cunningham cria então três personagens deprimidos: Virginia Woolf, Laura Brown e Richard. Woolf e Richard chegam a consumar o ato, mas Laura não, o que nos remete a uma proposta diferente de adaptação do autor. Mostrar que a fuga pode ser um alento à insegurança, à insatisfação e a angustia das horas e até mesmo à dor.

Outro ponto importante é que Woolf usa a Primeira Grande Guerra como possível fator de desequilíbrio para a piora do estado psicológico da personagem Septimus Smith (que sofria de depressão) em Mrs. Dalloway. Já em The Hours, ocorre mais uma "apropriação" de Cunningham quanto ao caso de Virginia Woolf (que realmente se suicidou), Laura Brown (que faz uma tentativa de suicício) e Richard (que também comete suicídio). Para as duas primeiras personagens, apenas o dia a dia era suficiente para deprimi-las. Woolf sofria de depressão e Brown de uma profunda tristeza. Para Richard o motivo é mais sério e também convoca a obra para o cenário contemporâneo: está deprimido porque sofre de AIDS. 
Além da referência à palavra vozes ("voices") no prólogo, encontramos em The Hours outros dois momentos em que a personagem Virginia Woolf se refere às doenças que a afligiam. Virginia também se queixava de fortes e constantes dores de cabeça, sofria de depressão e era tratada como louca. Ainda assim, ela parecia gozar de plena sanidade e ironizava a forma como era tratada por todos, em especial pelos médicos.

She can feel the headache creeping up the back of her neck. She stiffens. No, it's the memory of the headache, both of them so vivid as to be at least briefly indistinguishable from an onset of the headache itself. (1998, p. 164)

On the steps of Hogarth House, she pauses to remember herself. She has learned over the years that sanity involves a certain measure of impersonation, not simply for the benefit of husband and servants but for the sake, first and foremost, of one's own convictions. (1998, p. 83)

Através dessas passagens, podemos perceber que Woolf parecia bastante lúcida mesmo nos momentos em que sentia mais dores. Também mostra o quanto ela refletia sobre sua condição aparente de louca. A sanidade (mental) era um bem, mas dependia das convicções das pessoas.

\subsubsection{Suicídio, doença, Guerra e morte pelos Diários e Cartas}

Percebemos que em algumas cartas de Woolf para amigos o tema da Guerra também é recorrente, como nesta, de 13 de março de 1941 (apenas alguns dias antes de morrer), em que Woolf relata à amiga Elizabeth Robins sua constante preocupação com a Guerra então em curso:

Its amazingly peaceful here, you can almost hear the grass grow; and the rooks are building; you wouldn't think that at 7:30 the planes will be over. Two nights ago they dropped incendiaries, in a row, like street lamps, all along the downs. Two hay stacks caught and made a lovely illumination - but no flesh was hurt. Indeed, every bomb they drop only casts up a crater so far. Its difficult, I find, to write. No audience. No private stimulus, only this outer roar (1982, p. 479). 
A Guerra apavora Woolf e a mantém preocupada. Ela teme pela vida de seus parentes e amigos. Segundo vários relatos dos diários e cartas, a Guerra para Woolf só traz dor e morte. O tema da Guerra, portanto, está ligado ao da morte nos diários, cartas e também em Mrs. Dalloway. Em carta de 11 de setembro de 1940 a Ethel Smyth, amiga de longa data, Woolf já dizia, por exemplo: "Bombs were dropping round Sissinghurst" (1982, p. 430). Depois, em outro momento, ela diz: "now and then a bomb drops" (1982, p. 431). Em outra correspondência à mesma amiga, escrita em 20 de setembro de 1940, ela fala inclusive de como tentava desviar o pensamento sobre esse tema que tanto a preocupava e entristecia, como podemos ver a seguir: "I try to let down a fire proof curtain and go on reading, writing, cooking" (1982, p. 433).

Ao pesquisar mais algumas cartas de Woolf dessa mesma edição (1982), percebemos que ela de fato parecia bastante preocupada agora com as consequências da Segunda Grande Guerra (1939-1945), especialmente com os bombardeiros. Isso pode ser conferido em várias correspondências trocadas com amigos entre 1940 e 1941, seus dois últimos anos de vida. A seguir, apresentamos quatro trechos de cartas para diferentes amigos e em diferentes datas. Nesses excertos, ela externa sua preocupação com a segurança dos amigos e da família, sua inquietude em relação a algo que, como a Guerra, só causa dor e que parece não ter fim.

À William Plomer, em 15 de setembro de 1940.

I wish you were out of London. The bombs are getting much too close to one's friends (1982, p. 431). À Hugh Walpole, em 29 de setembro de 1940.

We drove up to Meck Sqre on Tuesday morning and found - well, what you saw. The bomb had fallen that night. I'm glad we weren't there (1982, p. 435).

$\dot{A}$ Lady Simon, em 25 de janeiro de 1941.

I dont see whats (to) be done about war. Its manliness; and manliness breeds womanliness - both so hateful (1982, p. 464). 
O tema da morte é uma constante nos escritos de Woolf. Em quase todos os seus romances, alguma personagem morre - inclusive, de maneira trágica, como foi o caso de Septimus Smith em Mrs. Dalloway (1925). Percebemos que em seus diários e também em correspondências com amigos e familiares Woolf também já demonstrava certa afeição por esse tema. No trecho abaixo, por exemplo, Woolf fala da intenção de escrever sobre a morte, de suas incertezas sobre uma vida longa por conta da doença. Esse trecho foi retirado do volume dos diários de Woolf discutido nesta tese (1980). Aqui percebemos ainda a menção que Woolf faz ao cenário de natureza em que vivia e do quanto isso a distrai por alguns instantes dessa ideia.

I meant to write about death [...]. I have taken it into my head that I shan't live till 70. Suppose, I said to myself the other day this pain over my heart suddenly wrung me out like a dish cloth \& left me dead? - I was feeling sleepy, indifferent, \& calm; \& so thought it didn't much matter, except for L. Then, some bird or light I daresay, or waking wider, set me off wishing to live on my own - wishing chiefly to walk along the river \& look at things (sexta-feira, 17 de fevereiro de 1922). (1982, p. 168)

Para reforçar nossa tese do quanto especialmente as cartas de suicídio influenciaram a elaboração da personagem Virginia Woolf em The Hours, transcrevemos a seguir outra correspondência para Leonard Woolf (1982, p. 485-7), provavelmente ${ }^{27}$ escrita no dia 28 de março de 1941, e destacamos alguns trechos em negrito:

Dearest,

I want to tell you you have given me complete happiness. No one could have done more than you have done. Please believe that.

But I know that I shall never get over this: and I am wasting your life. It is madness. Nothing anyone says can persuade me. You can work, and you will be much better without me. You see I cant write this even, which shows I am right. All I want to say is that until this disease came on we were perfectly happy. It was all due to you. No one could have been so good as you have been, from the very first day till now. Everyone knows that. You will find Roger's letters to the Maurons in the writing table drawer in the Lodge. Will you destroy all my papers.

British Library

$$
\text { V. }
$$

Virginia's body was found by some children, a short way down-stream, on 18 April, and an inquest was held next day at Newhaven. The verdict was 'Suicide while the balance of her mind was disturbed'. Her body was cremated at Brighton on 21 April, with only Leonard present, and her ashes were buried under a great elm-tree just outside the garden at Monk's House, with the last words of The Waves as her epitaph, "Against you I will flying myself, unvanquished and unyielding, O Death!".

\footnotetext{
${ }^{27}$ As datas não são precisas, segundo a pesquisa dos editores Nigel Nicolson e Joanne Trautman.
} 
Os trechos marcados mostram o quanto Woolf estava determinada a tirar a própria vida. Parece uma decisão muito pensada e nada nem ninguém a fará retroceder. Ela deixa algumas recomendações e parece agir de forma muito calculada. Uma dessas recomendações é que Leonard destrua seus papéis. Aqui, ela deve estar se referindo aos diários, escritos particulares, rascunho de contos, ensaios e romances e até mesmo às cartas de despedida. Felizmente, a família da escritora não seguiu esse último desejo de Woolf, conservando-os para a posteridade. Foi através das informações contidas nesse material que Cunningham pôde reescrever a obra woolfiana em The Hours.

Há ainda a carta de despedida a Vanessa Bell (talvez ${ }^{28}$ escrita em um domingo, 23 de março de 1941). Esse texto tem um tom mais ameno e Woolf, por vezes, demonstra certa culpa ao falar de Leonard. Ela pede insistentemente à sua irmã que confirme o que ela já escreveu em outras duas cartas: quanto ele foi bom para ela e que tudo o que poderia ser feito ele havia feito. Também fala dos sobrinhos com afeto e termina declarando sua impotência diante da doença.

Dearest,

You cant think how I loved your letter. But I feel that I have gone too far this time to come back again. I am certain now that I am going mad again. It is just as it was the first time, I am always hearing voices, and I know I shant get over it now.

All I want to say is that Leonard has been so astonishingly good, everyday, always; I cant imagine that anyone could have done more for me than he has. We have been perfectly happy until the last few weeks, when this horror began. Will you assure him of this? I feel he has so much to do that he will go on, better without me, and you will help him.

I can hardly think clearly any more. If I could I would tell you what you and the children have meant to $\mathrm{me}^{29}$. I think you know.

I have fought against it, but I cant any longer.

Virginia $^{30}$

Quanto ao estado avançado da doença de Woolf, que àquela altura já a impedia de escrever, Cunningham (nos trechos do prólogo em negrito "voices" e

\footnotetext{
${ }^{28}$ Consta nessa edição que algumas datas são imprecisas por conta do estado mental da escritora.

${ }^{29}$ Virginia sempre nutriu grande carinho pelos sobrinhos, filhos de sua irmã Vanessa Bell.

${ }^{30}$ (1982, p. 485, grifos nossos)
} 
"She has failed, and now the voices are back") pode ter se baseado em algumas queixas que Woolf relatou através de outras duas cartas à amiga Ethel Smyth, em 24 de dezembro de 1940 e $1^{\circ}$ de fevereiro de 1941. Na primeira, ela descreve os primeiros sintomas e, na segunda, já percebemos o avanço da doença, quando Woolf já não conseguia criar, seu maior prazer e distração. Ela diz:

I've been so badgered, that as you see, my hand trembles. Its partly that damned mess of books and things; I cant make a warm hollow for myself; my mind is churned and frothed; and to write one must be a clear vessel. (1982, p. 453)

I read and read like a donkey going round and round a well; pray to God, some idea will flash. I leave it to nature. I can no longer control my brain. (1982, p. 465)

Concluímos que Woolf convoca os temas da doença e da morte para despedir-se e justificar-se aos parentes. É fato que Cunningham pode ter se baseado nessas repetidas menções à doença para ressaltá-la logo no início de The Hours.

\subsection{Insegurança e antipatia em The Hours}

Outro tema compilado por Cunningham através da leitura das cartas de Woolf (1982) está relacionado à insegurança da escritora quanto à qualidade dos seus textos. Um trecho do prólogo apresentado anteriormente consolida essa constatação:

She is not a writer at all, really; she is merely a gifted eccentric. Patches of sky shine in puddles left over from last night's rain. Her shoes sink slightly into the soft earth. She has failed, and now the voices are back (grifo nosso).

Essa observação de Cunningham ("She is not a writer at all, really; she is merely a gifted eccentric") reitera novamente o espírito bastante autocrítico de Woolf 
sobre sua obra. Confirmaremos isso através de algumas passagens dos diários que apresentadas adiante. Também encontramos logo no primeiro capítulo de The Hours intitulado Mrs. Woolf o momento em que Cunningham reapresenta Woolf como personagem (já a havia introduzido ao leitor no prólogo) e ressalta seu estado bastante autocrítico. Ele se refere a algo que Woolf repetia não apenas na época em que escreveu o romance Mrs. Dalloway, mas em vários outros momentos até o final de sua vida: não se considerava grande escritora, embora muitos críticos em vida a tivessem elogiado. O ano é 1923 e o narrador Cunningham fala da insegurança de escritora com relação ao seu próprio ofício e de como ela se percebe instável na carreira e na forma de produzir:

\begin{abstract}
It is an inner faculty that recognizes the animating mysteries of the world because it is made of the same substance, and when she is very fortunate she is able to write directly through that faculty. Writing in that state is the most profound state satisfaction she knows, but her access to it comes and goes without warning. She may pick up her pen and follow it with her hand and it moves across the paper; she may pick up her pen and find that she's merely herself, a woman in housecoat holding a pen, afraid and uncertain, only mildly competent, with no idea where to begin or to write. ${ }^{31}(1998$, p. 35)
\end{abstract}

Outro tema percebido e abordado por Cunningham em The Hours é a implicância de Woolf com relação aos empregados de sua casa, especialmente com a cozinheira Nelly e seu mau humor característico. A seguir, transcrevemos um desses momentos em The Hours:

\footnotetext{
${ }^{31}$ É uma faculdade interior que reconhece os mistérios animados do mundo porque é feita da mesma substância, e, quando está com sorte, Virginia consegue escrever diretamente fazendo uso dessa faculdade. Escrever nesse estado é a satisfação mais profunda que conhece, mas seu acesso a ele vai e vem, sem aviso. Um dia pode apanhar a caneta e segui-lo com a mão que se move pelo papel; num outro, pode pegar a caneta e descobrir que é apenas ela mesma, uma mulher de chambre segurando uma caneta, com medo e incerta, apenas razoavelmente competente, sem a mínima ideia de onde começar ou do que escrever (1999, p. 34).
} 
She turns from the window. If she can remain strong and clear, if she can keep on weighing at least nine and half stone, Leonard will be persuaded to move back to London. The rest cure, these years among the delphinium beds and the red suburban villas, will be pronounced a success, and she will be deemed for the city again. Lunch, yes; she will have lunch. She should have breakfast but she can't bear the interruption it would entail, the contact with Nelly's mood. ${ }^{32}$ (1998, p. 35).

\subsubsection{Insegurança e antipatia de Woolf pelos Diários e Cartas}

Como reconhecida escritora do modernismo inglês, Woolf era bastante exigente quanto às suas próprias narrativas de ficção, conforme podemos ver em uma carta ao editor John Leemann, pedindo que lesse/editasse seu último romance, Between the Acts (1941), por considerá-lo simples demais. Essa carta mostra uma escritora insegura quanto ao próprio trabalho, que já era bastante reconhecido na Inglaterra e em vários países do mundo àquela altura. Mas isso não bastava para ela. A ideia de ver publicado algo que não agradaria o leitor (porque naquele momento já não agradava a ela mesma) enlouquecia Woolf.

Conforme pesquisa no vol. VI das cartas de Woolf (1980, p. 481), Woolf e Leonard haviam encontrado John Lehmann em Londres no dia 14 do mês de março de 1941 (apenas alguns dias antes da morte de Woolf) para pedir que ele fizesse uma revisão crítica da primeira versão do romance Between the Acts (WOOLF, 1941). Alguns dias depois (no dia 20 de março), ela escreve a Leehmann e, já bastante afetada pela depressão, parece insegura quanto à publicação desse romance. Ela pede inclusive que Lehmann decida entre publicá-lo ou não (1980, p. 482).

\footnotetext{
${ }^{32}$ Sai da janela. Se ela conseguir se manter forte, as ideias claras, se conseguir se manter no mínimo com sessenta quilos, Leonard talvez se deixe persuadir a voltar para Londres. A cura pelo descanso, esses anos entre canteiros de esporinhas e casarões de tijolo aparente serão considerados um sucesso e ela estará apta para viver na cidade de novo. Almoço, sim; ela vai almoçar. Devia comer alguma coisa no café da manhã, mas não suporta a interrupção que isso acarretaria, o contato com os humores de Nelly (1999, p. 34).
} 
Dear John,

I've just read my so called novel (Between the Acts) over; and I really dont think it does. Its much too slight and sketchy. Leonard doesnt agree. So we've decided to ask you if you don't mind reading it and give your casting vote? Meanwhile dont take any steps.

I'm sorry to trouble you, but I feel fairly certain it would be a mistake from all points of view to publish it. But as we both differ about this, your opinion would be a great help.

Yours

Virginia

Segundo Woolf, publicar o livro seria um erro, embora no mesmo ano em que foi lançado (1941) o jornal americano The New York Times (STRODE, 1941) tenha publicado uma crítica bastante elogiosa feita pelo professor americano Hudson Strode a esse romance. Cunningham chega a afirmar em entrevista sobre Woolf que o medo relacionado ao lançamento desse último trabalho também pode ter levado a escritora ao suicídio (2011b). Aqui vemos a escritora insegura quanto à sua obra e isso já ocorria desde o momento em que redigia Mrs. Dalloway, entre os anos 1920 e 1924, conforme mostraremos a seguir também com trechos dos diários da escritora (WOOLF, 1980).

Nossa intenção ao mostrar cartas como essa, endereçada a Leehmann, baseia-se na ideia que, embora não elas apareçam transcritas de forma direta em The Hours, elas evidenciam um lado muito frágil da escritora que, acreditamos, Cunningham procurou ressaltar e "adaptar" em seu romance, especialmente nos capítulos em que narra a vida de Woolf. Esse lado frágil se tornou mais evidente certamente por causa do estado mental da escritora nessa época.

Também o segundo volume dos diários (1980), apesar de tratar de anos bem anteriores à morte da escritora - entre 1920 e 1924 -, já revela ao leitor sua insegurança quanto a seus trabalhos e também suas preocupações com a doença, que já a assolava desde muito cedo. No primeiro trecho, transcrito na tabela a seguir, ela se revela desacreditada como escritora e comenta a falta de inspiração 
para começar um novo romance diante dos afazeres do dia a dia. No segundo, Woolf fala em tom crítico a respeito de uma senhora bastante preocupada com as aparências, ao mesmo tempo que diz que não se via assim como uma grande escritora (p. 11-12):

For one thing, I find it difficult to write. I held my pen this morning for two hours \& scarcely made a mark. The marks I did make were mere marks, not rushing into life \& heat as they do on good days. Perhaps Roger was the first cloud; Desmond may have contributed a little; \& then how many silly things I did yesterday, ending by ringing up the Richmonds at their dinner, \& being painfully snubbed by Helena on that account. I should like here to analyse [...] $(1980$, p. 11)

However the pathetic is not her line. She talks it to fill up space; but if I could reproduce her talk of money, royalties, editions, \& reviews, I should think myself a novelist; \& the picture might serve me for a warning. I think one may assume it to be more a product of the 90ties than of our age. Sábado, 24 de janeiro de 1920. (1980, p. 11-12)

Em outro relato, do dia 04 de fevereiro de 1920, ela critica o próprio romance The Voyage Out (1915) e comenta sobre o quanto gosta de criar personagens femininas e explorar suas mentes. Revela ainda como se vê no futuro. Diversas personagens femininas como Mrs. Dalloway sem dúvida imortalizaram a escritora inglesa nesse sentido.

The mornings from 12 to 1 I spend reading the Voyage Out. l've not read it since July 1913. And if you ask me what I think I must reply that I don't know - such a harlequinade as it is - such an assortment of patches - here simple \& severe - here frivolous \& shallow - here like God's truth - here strong \& free flowing as I could wish. What to make of it, Heaven knows. The failures are ghastly enough to make my cheeks burn in a different way. On the whole I like the young womans mind considerably. How gallantly she takes her fences - \& my word, what a gift for pen \& ink! I can do little to amend: \& must go down to posterity the author of cheap witticisms, smart satires \& even, I find, vulgarisms - crudities rather - that will never cease to rankle in the grave. $(1980$, p. 17$)$

Ainda no dia 26 de janeiro de 1920 (1980, p. 13-14), Woolf comenta sobre seu estado mental e a inspiração para começar um novo livro - nesse caso, Mrs. Dalloway. Ela reflete sobre o passar do tempo e o quanto seu processo criativo é 
instável. Woolf relata ainda o trabalho em torno dos contos Kew Gardens ${ }^{33}$ e The Mark on the Wall, ${ }^{34}$ como também de um futuro livro, chamado por enquanto de "unwritten novel". Este último corresponde ao romance Mrs. Dalloway.

The Day after my birthday; in fact I'm 38. Well, I've no doubt I'm a great deal happier than I was at 28; \& happier today than I was yesterday having this afternoon arrived at some idea of a new form for a new novel. Suppose one thing should open out for another - as in An Unwritten Novel - only not for 10 pages but 200 or so - doesnt that give the looseness \& lightness I want: doesnt that get closer \& yet keep form \& speed, \& enclose everything, everything? My doubt is how far it will (include) enclose the human heart - Am I sufficiently mistress of my dialogue to net it here? For I think the approach will be entirely differently this time: no scaffolding; scarcely a brick to be seen; all crepuscular, but the heart, the passion, humour, everything as bright as fire in the mist. Then l'll find room for so much - a gaiety - an inconsequence - a light spirited at my sweet will. Whether I'm sufficiently mistress of things - thats the doubt; but conceive Mark on the wall, K(ew). G(ardens). \& unwritten novel taking hands and dancing in the unity. What the unity shall be I have yet to discover: the theme is a blank to me but I see immense possibilities in the form I hit upon more or less by chance 2 weeks ago.

Em outro momento, Woolf comenta os elogios que seu marido Leonard (L.) faz ao romance Jacob's room, publicado 1922. Ela descreve seu processo criativo e de certa forma aceita o elogio, porém sem levar em consideração algumas observações de Leonard.

On Sunday L. read through Jacob's Room. He thinks it is my best work. But his first remark was that it was amazingly well written. We argued about it. He calls it a work of genius; he thinks it unlike any other novel; he says that the people are ghosts; he says it is very strange. I have no philosophy of life he says; my people are puppets, moved hither \& thither by fate. He doesn't agree that fate works in this way. Thinks I should use my 'method', on one or two characters next time; \& he found it very interesting, \& beautiful, \& without lapse (save perhaps the party) \& quite intelligible. [...] Neither of us knows what the public will think. There's no doubt in my mind that I have found out how to begin (at 40) to say something in my own voice; \& that interests me so that I feel I can go ahead without praise (quarta-feira, 26 de junho de 1922).(1980, p. 186, grifos nossos)

Adiante, Woolf faz uma previsão sobre como seria vista no futuro: uma escritora bem longe do popular, fato que se concretizou. Ocorre que esta tese procura mostrar que as refrações da obra de Woolf anteriores a The Hours também reiteraram esse aspecto. Assim, a obra woolfiana circulava somente nos círculos

\footnotetext{
${ }^{33}$ Publicado originalmente em 1919 e 1921, sua publicação mais ampla se deu na coletânea Monday or Tuesday (WOOLF, 1921). Em português, foi traduzida por Leonardo Fróes na coletânea Contos Completos (WOOLF, 2005).

${ }^{34}$ Idem ao conto anterior, porém publicado pela primeira vez em 1917.
} 
acadêmico e de crítica literária. Em outras palavras, apenas os professional readers (LEFEVERE, 1992a) conheciam Virginia Woolf. Esta tese tenta mostrar ainda que foi Cunningham, através do romance The Hours, quem procurou por uma ampliação dos leitores de Woolf na contemporaneidade para além do meio acadêmico.

Once more my mind is distracted from the thought of death. There was something about the fame I had it in mind to say yesterday - oh I think it was that I have made up my mind that I'm not going to be popular, \& so genuinely that I look upon disregard or abuse as part of my bargain. I'm to write what I like; \& they're to say what they like. My only interest as a writer lies, I begin to see, in some queer individuality: not in strength, or passion, or anything startling; but then I say to myself, is not 'some queer individuality' precisely the quality I respect? (sábado, 18 de fevereiro de 1922). (1980, p. 168)

Os dois exemplos a seguir servirão para confirmar outra prerrogativa da personagem Virginia Woolf em The Hours: seu lado elitista e sua implicância com relação aos empregados, em especial à sua cozinheira Nelly. Essa característica aparece em diversas passagens do romance de Cunningham nos capítulos Mrs. Woolf.

O primeiro trecho foi retirado de uma carta de Woolf à sua irmã, Vanessa Bell, no ano 1921. Nessa passagem, Woolf demonstra sua implicância com relação a Nelly Boxall por não aceitar as reclamações da funcionária, o que alerta o leitor para uma difícil convivência entre as duas. A empregada de Vanessa Bell também se chamava Nelly e Woolf, irritada, imagina uma conspiração formada pelas duas. Ela acredita que a "sua Nelly" planeja deixá-la, para, então, ir trabalhar para Vanessa. No segundo exemplo, uma anotação em diário que data de 15 de setembro de 1920 (1982, p. 64), Woolf se declara bastante elitista. Ela é influenciada pelos amigos intelectuais e aristocratas e, dessa forma, diz abertamente não gostar dos empregados e das classes menos favorecidas. Sua empregada precisou se ausentar para fazer exames e isso deixou Woolf impaciente. 
I looked into my consult about the servants. Angelica is perfectly well and had a very good night. But his morning my Nelly (Boxall) gave me notice on the ground that we had too many people yesterday. I feel pretty certain that the real reason is that she and your Nelly (Brittain) have arranged that she is to offer to come to you. [...] I merely said that she had much better go if she thought the place too hard. V. (1982, p. 498, grifo nosso)

Nelly has now had, I suppose every organ in her body examined, \& is pronounced healthy with the exception of her teeth. So that shot of mine seems true true one; - but I confess I don't look forward to the winter. The fact is the lower classes are detestable. (1982, p. 64, grifo nosso)

Por fim, percebemos que o adaptador Cunningham escolheu grande parte dos temas debatidos em The Hours através de pesquisa realizada especialmente nos diários e cartas de Woolf. Com sua proposta de "apropriação", e de acordo com critérios particulares de preferência, o autor selecionou esses temas e os adaptou para o romance The Hours. Assim, ele forma a personalidade woolfiana de uma forma mais direta nos capítulos intitulados Mrs. Woolf. É uma oportunidade para o leitor comum conhecer a vida privada da escritora inglesa e entender melhor suas personagens e propostas narrativas.

\subsection{Mrs. Dalloway em The Hours}

Mrs. Dalloway said something (what?), and got the flowers herself. It is a suburb of London. It is 1923.

Virginia awakens. This might be another way to begin, certainly; with Clarissa going on an errand on a day in June, instead of soldiers marching off to lay the wreath in Whitehall. But is it the right beginning? Is it a little too ordinary $?^{35}$

O trecho de The Hours citado acima (1998, p. 29) está na primeira página do primeiro capítulo intitulado Mrs. Woolf, dentre aqueles presentes no livro dedicados a descrever o dia a dia de Virginia Woolf à época em que escrevia o romance Mrs.

\footnotetext{
${ }^{35}$ Mrs. Dalloway disse alguma coisa (o quê?) e comprou ela mesma as flores. Estamos nos arredores de Londres. No ano de 1923. Virginia acorda. Talvez essa seja um outro jeito de começar, quem sabe; com Clarissa saindo de casa encarregada de fazer algo, numa manhã de junho, em vez de um batalhão de soldados marchando para depositar uma coroa de flores em Whitehall. Mas seria o começo correto? Não seria um pouco banal demais? (1998, p. 29)
} 
Dalloway, publicado em 1925 pela Hogarth Press, editora do casal Virginia e Leonard Woolf. Essa narrativa mostra um dia na vida da personagem Clarissa Dalloway, protagonista desse romance, também em Londres e no ano de 1923.

Mrs. Dalloway (1925) é uma narrativa complexa em que Woolf prioriza o uso do fluxo de consciência para descrever os pensamentos de suas personagens, o que o levou a ser classificado como moderno à época, um trabalho de vanguarda. Como Woolf prioriza o uso do fluxo de consciência, é fácil conhecer o estado psicológico das personagens durante a narrativa, além de seus pensamentos, aflições e opiniões.

Aliás, são essas reflexões e também as memórias das personagens que dão rumo à história, visto que não há um acontecimento delimitador de clímax. Os poucos eventos dessa história, como a saída de Dalloway para comprar flores e organizar a festa que dará mais tarde, são triviais, à exceção do suicídio da personagem Septimus Smith.

Dalloway se vê em um dia aparentemente comum, mas é nessa ocasião que outras personagens (que com ela se relacionaram) e cenas do passado retornam à sua vida, forçando-a a analisar as escolhas que fez. Há uma alternância constante do passado com o presente em Mrs. Dalloway, algo que Cunningham também procurou adaptar em The Hours ao propor capítulos alternados sobre três personagens, cada uma em uma época diferente. Aliás, Cunningham (2011a), em depoimento sobre Mrs. Dalloway, confirma nossas palavras sobre esse romance ao dizer que ele: 
[...] se enreda e se desenreda. Tem as pontas soltas. Ele é coerente, mas da maneira desordenada como a própria vida é coerente. Como a própria vida, ele tem padrões e temas, mas não é exatamente sobre alguma coisa singular ou facilmente identificável. Ele trata de si mesmo.

Em The Hours, embora em capítulos alternados, ocorre uma inter-relação entre as três personagens principais: Virginia Woolf, que escreve Mrs. Dalloway na Inglaterra dos anos 1920 e sofre de depressão, morrendo nos anos 1940; Laura Brown, que lê um romance de Woolf ainda nos anos 1940, conhece sua história e parece se inspirar com ela; e Clarissa Vaughan, já nos anos 1990, reproduzindo o mesmo mote da personagem Clarissa Dalloway de Woolf e se relacionando com Richard, o filho abandonado de Laura Brown.

Aspectos intrincados de Mrs. Dalloway também tornaram o estilo narrativo de Woolf bastante incomum para a época em questão, despertando grande interesse da crítica literária e do público leitor. A obra é uma incursão na mente da escritora Virginia Woolf e de suas personagens, o que nos convida a uma reflexão sobre os conflitos internos de todos os homens.

A protagonista de Mrs. Dalloway é Clarissa Dalloway, uma mulher elitista que - como Virginia Woolf - também frequenta a alta sociedade inglesa dos anos 1920. Ela tem 52 anos e ama a vida. É uma personagem frívola e que parece confortável em meio a tantas convenções sociais, embora pareça muito preocupada com a imagem que as pessoas têm dela. Seus afazeres, aparentemente fúteis, mostram certo vazio em sua vida e isso a leva a constantes diálogos consigo mesma.

Aliás, Clarissa compartilha de suas reflexões sobre a vida com o leitor em diversos momentos. Primeiro quanto à decisão de casar-se com Richard Dalloway ou com o amigo Peter Walsh. Nesse ponto, começa a questionar o verdadeiro 
sentido da vida, que ora a empolga e ora a amedronta. Ela vive um embate constante entre manter sua privacidade e, ao mesmo tempo, comunicar-se socialmente, o que para ela é uma necessidade. Ela é casada com Richard Dalloway, um homem sempre ocupado com seu trabalho. Os dois têm uma filha de 17 anos chamada Elizabeth. Ocorre que Clarissa, na verdade, nutre uma paixão por Sally Seton, também casada e com quem Clarissa se envolveu nos tempos de juventude, sentimento esse que nunca será concretizado.

Outra personagem importante dessa narrativa é o já citado Septimus Smith, que sofre de uma série de transtornos psicológicos especialmente por sua participação na Primeira Grande Guerra e pela perda do amigo Evans, morto durante a Guerra. Percebemos que a ligação entre os oficiais Smith e Evans ultrapassava a amizade, funcionando na história como outro núcleo gay, além de Clarissa e Sally.

É importante citar que as histórias de Smith e Clarissa Dalloway são contadas em paralelo, até que Dalloway fica sabendo do suicídio de Smith no meio da festa por ela realizada e elogia a coragem dele por isso, revelando naquele momento certa admiração pelo comportamento de Smith. Na verdade Smith e Dalloway nunca se encontram. O único ponto de convergência entre as duas personagens é a ida de Smith ao consultório do Dr. Bradshaw, que já foi psiquiatra de Clarissa no romance.

Smith é chamado de "o duplo de Dalloway", e os dois têm personalidades muito parecidas, à exceção da loucura de Smith e a aparente normalidade e alegria de Dalloway. Ambos são personagens que nos presenteiam com profundas reflexões sobre a angústia entre preservar-se socialmente ou compartilhar dos próprios pensamentos com os outros. Smith, antes bonito e aspirante a poeta, volta 
da Guerra amargo e revoltado com a natureza humana, que agora considera como naturalmente perversa. Ele entra no romance logo depois do reencontro entre Clarissa e Peter Walsh, velho amigo de Clarissa e por ela eternamente apaixonado. Depois desse encontro, Walsh vai para o Regent's Park e lá observa Smith.

Cabe aqui ressaltar a nossa percepeção de que Woolf alterna especialmente o uso de narração onisciente, do discurso indireto livre e do monólogo interior (COHN, 2000) para compartilhar com o leitor os pensamentos de suas personagens. Smith é inclusive uma das personagens que mais reflete sobre sua vida ao longo do romance, o que mostra uma tentativa da escritora Woolf de fazer com que o leitor não julgue a decisão de Smith em suicidar-se.

Assim como fez Woolf em Mrs.Dalloway, também Cunningham escolheu de forma mais preponderante o monólogo interior (COHN, 2000) em The Hours, conforme já discutimos anteriormente, para fazer com que suas personagens se apresentem ao leitor. Dessa forma o leitor será capaz de descrever personalidade, sentimentos e aflições de cada personagem. Em Mrs. Dalloway o narrador inicialmente apresenta Clarissa Dalloway em todos os seus desejos naquele momento de sua vida. No romance de Cunnigham, logo após o prólogo em que Woolf comete suicídio, o leitor é levado a conhecer Clarissa Vaughan no capítulo Mrs. Dalloway. Ela sai de casa em uma manhã do final do século XX (anos 1990) para comprar flores, tal qual fez a Clarissa de Woolf em Mrs. Dalloway. Essas flores serão usadas na decoração de sua casa para a festa que dará logo mais a noite em homenagem ao amigo Richard.

Clarissa Vaughan não é uma socialite, mas leva uma vida confortável, como a Clarissa de Woolf. Ela tem 52 anos, assim como Clarissa Dalloway, é editora de 
livros e mora no bairro de Greenwich Village, em Nova lorque. Clarissa, enfim, sente-se aparentemente feliz em dar uma festa a Richard. Também se considera feliz em viver com sua filha Julia e com Sally, sua esposa. Seu melhor amigo Richard às vezes critica essa felicidade vazia de Vaughan e a vida fútil que ela leva. As palavras de Richard, por vezes, a levam à reflexão. Por essas e outras semelhanças é que percebemos claramente a Clarissa Dalloway de Woolf modernizada na Clarissa Vaughan de Cunningham em The Hours.

É possível que outra apropriação de Cunningham em The Hours seja exatamente a relação entre Clarissa Vaughan e Richard, uma alusão à relação inexistente entre Clarissa Dalloway e Septimus Smith em Mrs. Dalloway. Cunningham promoveu esse encontro pensando no que diria Smith a Dalloway, caso os dois fossem amigos. A própria festa que Dalloway passou o dia organizando em Mrs. Dalloway seria algo a ser criticado por Smith. Assim faz Richard com Clarissa Vaughan em The Hours. Ela planeja dar uma festa naquele dia para homenageá-lo pela premiação recebida pelo seu romance. Ele ironiza a festa e o prêmio, que, segundo ele, foi dado por sua condição terminal (e não pelo mérito da obra). A descrença de Richard no próprio trabalho muitas vezes lembra a de Woolf em seus diários e cartas. Woolf frequentemente se mostrava bastante autocrítica quanto a seus romances e a personagem Virginia Woolf de Cunningham também procurou mostrar esse lado.

Convém relembrar os trabalhos acadêmicos de referência sobre o romance Mrs. Dalloway de Woolf, inclusive publicados no Brasil. No de Carlos Silva (2007), por exemplo, esse autor explica como e porque tanto a adaptação fílmica de 1997, o livro de Cunningham (1998) e o filme homônimo (2002) "reescrevem" apenas a personagem Mrs. Dalloway e o romance de mesmo nome no contexto atual da 
época em que foram lançados. De acordo com Silva, o foco principal desse trabalho foi tentar mostrar o papel do cinema como importante "agente de reescrita" do romance canônico Mrs. Dalloway. Ao final dessa pesquisa, o autor sugere inclusive a ampliação em torno da discussão sobre as reescritas de Woolf, dada a complexidade de seus textos.

Ocorre que também verificamos na obra The Hours grande complexidade com relação à forma como foi elaborada. Mais ainda: de acordo com esta tese, para "reescrever" The Hours, Michael Cunningham fez uso não apenas do romance Mrs. Dalloway, mas também dos diários da escritora, cartas, um ensaio crítico, temas trabalhados em outros romances e dados sobre sua vida pessoal que constam em biografias. Enfim, The Hours é a reescrita da "obra" de Virginia Woolf em um sentido mais amplo.

Dessa forma, o papel significativo dos diários e cartas para a construção de The Hours mereceu uma investigação. Se Silva (2007) procurou ater-se ao diretor da adaptação de Mrs. Dalloway para o cinema (1997) e também de Stephen Daldry, diretor do filme The Hours (2002), como tradutores ou agentes de reescrita do romance canônico Mrs. Dalloway (1925), nós nos dedicamos integralmente à questão literária e a Michael Cunningham, autor/adaptador do romance The Hours, como o principal agente de reescrita da "obra" woolfiana na contemporaneidade.

Pautamos essa pesquisa na área dos Estudos da Tradução e da Adaptação, por isso direcionamos nosso olhar para o mercado editorial de traduções e adaptações literárias, especialmente o do Brasil. Dizemos isso pois Cunningham atuou, de maneira geral, como um agente de apresentação da "obra" de Woolf para novo públicos leitores, não necessariamente estrangeiros. Através de uma proposta 
narrativa ousada, ele dialoga com esses novos leitores, tanto quanto com aqueles chamados professional readers (LEFEVERE, 1992a), mais acostumados à leitura dos trabalhos e refrações de Woolf.

Conforme a pesquisa que apresentaremos adiante sobre as traduções das obras escritas por Virginia Woolf no nosso país, a proposta de Cunningham e as "apropriações" em torno de certos temas, personagens e acontecimentos relacionados à obra woolfiana é o fator mais diretamente responsável por uma ampliação no número de leitores dessa autora inglesa, ao menos no Brasil. Dizemos isso por conta do levantamento que fizemos (CARIBÉ, 2011), através do qual ficou comprovada uma maior frequência na publicação de novas edições das obras de Woolf no Brasil, algo que não se via nos anos anteriores à publicação de As Horas (1999). Isso ocorre pela forma como Cunningham retoma algumas discussões inicialmente propostas por Woolf e também apresenta as suas próprias ao longo de seu romance. Esse fato reforça nossa tese sobre as "apropriações" (SANDERS, 2006) de Cunningham como fator decisivo para a consolidação de The Hours como reescrita da "obra" woolfiana.

O leitor contemporâneo poderá perceber um diálogo entre o escritor Michael Cunningham e a "obra" de Woolf, de acordo com as ideias que o autor selecionou para serem desenvolvidas em seu romance. A presença do escritor é certamente sentida e, assim, a narrativa poderá servir de convite para esses novos leitores conhecerem a "obra" de Woolf.

Percebemos também que uma das estratégias que Cunningham mais utiliza para reescrever de forma mais direta o romance Mrs. Dalloway em The Hours é reproduzir frases retiradas dessa narrativa ou adaptá-las ao novo contexto, como no 
exemplo citado no início desse tópico, retirado do capítulo Mrs. Woolf. Nesse trecho, o leitor é convidado a imaginar que Woolf estava elaborando em sua mente o início do romance Mrs. Dalloway e pensando exatamente na primeira frase desse texto e no que faria a personagem Clarissa Dalloway naquele dia do mês de junho.

Na sequência desse capítulo, o narrador Cunningham intervém de forma mais direta e começa a descrever para o leitor onde está Woolf (em casa, repousando...) e qual momento da história é esse (1923). Ao longo do capítulo, outras informações são acrescidas de forma que os non-professional readers (LEFEVERE, 1992a) poderão certamente compreender o contexto de intertextualidade que envolve a personagem Virginia Woolf e os capítulos Mrs. Woolf de The Hours, sem precisarem conhecer as fontes que os influenciaram.

No primeiro capítulo intitulado Mrs. Woolf (logo após o capítulo Mrs. Dalloway), Cunningham vai aos poucos deixando claro que Virginia Woolf é uma escritora inglesa no ano de 1923 que está angustiada enquanto cria um novo romance. Até aquele momento, Woolf só escreveu que a personagem desse romance se chama Clarissa e que aquele é mais um dia em sua vida. O leitor vai então vai gradualmente fazendo algumas ligações necessárias para uma melhor apreciação da obra - sendo relembrado, por exemplo, que no capítulo anterior, chamado "Mrs. Dalloway", o nome Clarissa já havia surgido pela primeira vez para apresentar outra personagem, a Clarissa Vaughan de Nova lorque.

Aliás, em The Hours há diversos momentos em que as fraseologias de Cunningham lembram muito as de Woolf em Mrs. Dalloway. Sobre isso, mostraremos dois exemplos a seguir. São trechos do primeiro capítulo intitulado Mrs. 
Dalloway de The Hours no qual frases do romance homônimo de Woolf são adaptadas por Cunningham.

\section{THE HOURS, de Cunningham (1998) \\ There are still flowers to buy. Clarissa feigns exasperation (though she loves doing errands like this), leaves Sally cleaning the bathroom, and runs out, promising to be back in half an hour (p. 9 , grifos nossos).}

\section{MRS. DALLOWAY, de Woolf (1925)}

Mrs. Dalloway said she would buy the flowers herself. For Lucy had her work cut out for her. The doors would be taken off their hinges; Rumpelmayer's men were coming. And then, thought Clarissa Dalloway, what a morning fresh as if issued to children on a beach. (p. 5, grifos nossos).

What a lark! What a plunge! For so it had always seemed to her when, with a little squeak of the hinges, which she could hear now, she had burst open the French Windows and plunged at Bourton into the open air (p. 5, grifos nossos).

Mesmo assim, a percepção dessas adaptações pelo leitor comum não comprometem seu entendimento do romance. Elas são uma espécie de prêmio para os leitores profissionais de Woolf, em especial àqueles que, desarmados de qualquer convenção, dedicam-se a apreciar uma narrativa que adapte elementos de narrativas canônicas sem criticá-la por ser mais próxima ou mais distante do textofonte. A leitura de The Hours também poderá ser realizada por leitores comuns, e essa forma de adaptar de Cunningham está de acordo com o que propõe Hutcheon (2006, p. 121) ao dizer que "for an adaptation to be successful in its own right, it must be so for both knowing and unknowing audiences". Em suma: uma boa adaptação é aquela que independe de pré-requisitos para leitura, precisa funcionar como aquele texto que comporta entendimento e explicações em si mesmo, sem necessariamente esperar que o leitor faça as referências textuais imaginadas.

A primeira frase do capítulo Mrs. Woolf, o segundo de The Hours, ("Mrs. Dalloway said something (what?), and got the flowers herself') foi inspirada na conhecida frase também de abertura do romance Mrs. Dalloway (1925): "Mrs. 
Dalloway said she would buy the flowers herself" (p. 5). Essa frase foi repetida outras vezes em The Hours por Laura Brown, como, por exemplo, na abertura do primeiro capítulo Mrs. Brown (terceiro capítulo de The Hours). Essa personagem também cita outros trechos de Mrs. Dalloway durante o romance The Hours. Assim, percebemos ecos de palavras e frases de Mrs. Dalloway em The Hours, especialmente nos capítulos Mrs. Brown e Mrs. Dalloway.

Podemos concluir então que a intenção de Cunningham é, principalmente através de Laura Brown e Clarissa Vaughan, dialogar com o leitor sobre a personagem Clarissa Dalloway do romance Mrs. Dalloway. Podemos conferir esse dado através de uma fala de Cunningham em entrevista sobre o quanto esse romance influenciou sua carreira, conforme podemos conferir a seguir (CUNNINGHAM, 1999):

\begin{abstract}
Virginia Woolf's great novel, "Mrs. Dalloway," is the first great book I ever read. I read it almost by accident when I was in high school, when I was 15 years old. I suspect any serious reader has a first great book, just the way anybody has a first kiss. For me it was this book. It stayed with me in a way no other book ever has. And it felt like something for me to write about very much the way you might write a novel based on the first time you fell in love, the first - your first seminal experience of any kind. This book feels like, I don't know, something that happened to me.
\end{abstract}

Concluímos também que a presença de Mrs. Dalloway em The Hours revela a intenção particular de apropriação do adaptador Cunningham de contar a história do romance Mrs. Dalloway de acordo com suas interpretações. Enfim, não obstante os romances que publicou, Cunningham desejava mesmo narrar a história de Clarissa Dalloway e a vida privada de Woolf.

A publicação de The Hours e o reconhecimento do público e da crítica literária com relação a esse romance revelam que as obras literárias são fonte eterna de 
inspiração e que muitas possibilidades de interpretação (como as adaptações literárias e fílmicas) acontecem cada vez que se refaz uma determinada leitura. Os agentes de reescrita, levando em consideração a já reconhecida carreira do escritor nos anos 1990, patrocinaram a proposta de Cunningham, mesmo sabendo dos perigos de rechaça e crítica que correm os escritores que adaptam textos de escritores canônicos. Esses agentes apostaram que Cunningham seria o escritor ideal para fazer a ponte entre a "obra" de Woolf e a contemporaneidade.

Há também uma frequente correspondência de nomes entre Mrs. Dalloway e The Hours. Aliás, o próprio título The Hours é outro exemplo de "apropriação" feito por Cunningham, segundo Sanders (2006). É que Woolf diz no prefácio de Mrs. Dalloway que The Hours era o título provisório de seu novo romance. Talvez essa apropriação se justifique pelo já mencionado grau de envolvimento do autor Cunningham com o romance Mrs. Dalloway e por sua enorme influência na criação de The Hours. Há outras apropriações de nomes, como a forma como a personagem Richard chama Clarissa Vaughan (Mrs. D ou Mrs. Dalloway).

O caso da apropriação do título por Cunningham em The Hours nos leva a uma discussão que lembra a proposta de Venuti (2004). Esse pesquisador reivindica uma maior visibilidade dos tradutores interlinguais nas traduções publicadas em outros países, que privilegiam na capa, por exemplo, apenas o nome do autor do texto-fonte. Venuti também reivindica uma maior estrangeirização dos textos traduzidos, exatamente para que a presença do tradutor seja mais rememorada a cada página lida.

O caso das adaptações literárias interlinguais ou intralinguais, é um pouco diferente. Normalmente o nome do adaptador é colocado na capa dessas narrativas 
porque, por ser mais conhecido na contemporaneidade, muitas vezes ele é o grande elo com o leitor pretendido (e não o autor do texto-fonte). O nome do autor é que acaba ficando algumas vezes em segundo plano. Isso ocorre porque o leitor contemporâneo muitas vezes desconhece os escritores canônicos.

Porém, para os professional readeres, conhecedores dos textos-fonte, a utilização do título de uma obra canônica em uma adaptação literária negligenciando ou omitindo o nome do autor do texto-fonte é algo inadmissível. É preciso, segundo os professional readers, ressaltar de alguma forma o papel das fontes para que o leitor entenda que o mote daquela narrativa não é original.

Aliás, essa polêmica sobre originalidade na literatura existe desde muito antes do surgimento do romance. O que percebemos é que existe uma espécie de vigília da crítica literária especializada no mundo todo a alguns padrões que jamais poderão ser repetidos. É como se dissessem que, depois da peça de Shakespeare Romeo and Juliet, escrita no final século XVI, jamais alguém poderá escrever uma história que tenha dois jovens apaixonados vindos de famílias inimigas.

Sem fazer apologia ao plágio ou à cópia, não deixaremos de nos manifestar quanto a essa posição da crítica literária, que consideramos equivocada. A literatura reflete a sociedade e é terreno fértil e eterno para conhecimento e interpretação de acontecimentos, temas e personagens. E, exatamente por refletir a sociedade, é que muitas vezes encontraremos correspondência de obras literárias do passado em outras da atualidade. Por isso mesmo é que não entendemos porque uma personagem de obra canônica não possa ser adaptada em novo contexto, como propõem muitas adaptações literárias e fílmicas. 
Podemos conferir a seguir três trechos do segundo volume dos diários (1980) de Woolf, que abrange os anos entre 1920 e 1924, em que Woolf faz algumas menções ao romance Mrs. Dalloway com o nome provisório The Hours. Ela se mostrava indecisa quanto a isso, ora se referindo ao romance como Mrs. Dalloway, ora como The Hours.

$\mathrm{Na}$ primeira passagem, de 19 de junho de 1923, Woolf questiona seu processo de criação e tudo o que gostaria de escrever naquela obra. Comenta ainda a crítica de Arnold Bennet a seu respeito e o quanto isso repercute nesse processo criativo (quase nada, segundo ela). Woolf prefere que os leitores escolham o destino que suas obras e personagens vão tomar na posteridade e explica exatamente o que deseja fazer e descrever em Mrs. Dalloway.

But now what do I feel about my writing? - this book, that is, The Hours, if thats its name? One must write from deep feeling, said Dostoevsky. And do I? Or do I fabricate with words, loving them as I do? No I think not. In this book I have almost too many ideas. I want to give life \& death, sanity \& insanity; I want to criticise the social system, \& to show it at work, as its most intense - But here I may be posing [...]. Am I writing The Hours from deep emotion? Of course the mad part tries me so much, makes my mind squint so badly that I can hardly face spending the next weeks at it. Its a question though of these characters. People, like Arnold Bennet, say I cant create, or didn't in J's $\boldsymbol{R}^{36}$ characters that survive. My answer is - but I leave that to the Nation: its only the old argument that character is dissipated into shreds now: the old post-Dostoevsky argument. I daresay its true, however, that I haven't that 'reality' gift. [...] Neverthless, I think it most important in this book to go for the central things, even though they dont submit, as they should however, to beautification in language. [...] I foresee, to return to The Hours, that this is going to be the devil of a struggle. The design is so queer \& so masterful. I'm always having to wrench my substance to fit it. The design is certainly original, \& interests me hugely. I should like to write away \& away at it, very quick and fierce. Needless to say, I cant. In three weeks from today I shall be dried up. (1980, p. 248-9)

Em outra passagem - um sábado, 29 de agosto de 1923 -, Woolf revela a angústia que enfrentou em alguns momentos relacionados ao processo de criação de Mrs. Dalloway. Ela declara ser esse seu livro mais provocante e subversivo. Também critica algumas partes do romance, mas sente que precisa finalizá-lo para então emitir novas opiniões a respeito.

\footnotetext{
${ }^{36}$ Jacob's Room, romance de Woolf publicado em 1922.
} 
I've been battling for ever so long with 'The Hours', which is proving one of my most tantalizing \& refractory of books. Parts are so bad, parts are so good; l'm much interested; can't stop making it up yet - yet. What is the matter with it? But I want to freshen myself, so will say no more. Only I must note this odd symptom; a conviction that I shall go on, see it through, because it interests me to write it. (1980, p. 262)

Já no sábado do dia 09 de fevereiro de 1924, ela se mostra mais otimista com o andamento do romance e o rumo que ele tomou. Revela ainda seu prazer pela escrita e o quanto a fala de Edward Morgan a impulsionou a continuar escrevendo da forma como vinha fazendo. Ela pretende na verdade explorar o lado psicológico das personagens, como fez em Jacob's room (1922).

I'm working at The Hours, \& think it a very interesting attempt; I may have found my mine this time I think. I may get all my gold out. The great thing is never to feel bored with one's own writing. That is the signal for a change - never mind what, so long as it brings interest. And my vein of gold lies so deep, in such bent channels. To get it I must forge ahead, stoop \& grope. But it is gold of a kind I think. Morgan ${ }^{37}$ said I had got further into the soul in Jacob's Room than any other novelist. (1980, p. 292)

Já em uma segunda-feira, do dia 05 de maio de 1924, Woolf planeja o término da obra, mas se mostra confusa quanto a isso. Ela contabiliza o número de palavras escritas até então e planeja chegar até as 80 mil. Para Woolf, Londres é o cenário ideal para isso. Essa cidade a inspira e a tira da estagnação.

But my mind is full of The Hours. I am now saying that I will write at it for 4 months, June, July, August \& September, \& then it will be done, \& I shall put it away for three months, during which I shall finish my essays; \& then that will be - October, November, December - January: \& I shall revise it January February March April; \& in April my essays will come out; \& in May my novel. Such is my programme. [...] Reading it remains. I aim at 80,000 words this time. And I like London for writing it, partly because, as I say, life upholds one; \& with my squirrel cage mind, it's a great thing to be stopped circling. Then to see human beings freely \& quickly is an infinite gain to me. And I can dart in \& out \& refresh my stagnancy. (1980, p. 301)

Essas passagens também demonstram o quanto Woolf passou por diversos estágios durante a escrita do romance Mrs. Dalloway nos anos 1920. Essa angústia, percebida por Cunningham, foi diretamente retratada em The Hours, como podemos ver em dois trechos dos capítulos Mrs. Woolf que apresentaremos a seguir. O

\footnotetext{
${ }^{37}$ Edward Morgan Foster (1879-1970) foi outro grande novelista dos anos 1920. Suas observações quanto à obra de Woolf eram quase sempre elogiosas, sendo muito respeitadas pela autora.
} 
primeiro trecho é parte de um diálogo entre Woolf e sua irmã, Vanessa, que estava em visita à casa de Woolf. Vanessa comenta de um casaco que gostaria de comprar para sua filha, Angélica. Nesse ínterim, Woolf começa a pensar no destino da personagem Clarissa Dalloway. O trecho mostra que, segundo Cunningham, Woolf cogitou que Dalloway cometeria suicídio, mas considerando-a fraca demais para tomar essa atitude, optou por Smith, que possui uma "greater mind".

Virginia nods. At the moment, she can't seem to speak. There is so much in the world. There are coats at Harrods; there are children who will be angry and disappointed no matter what one does. There is Vanessa's plump hand on her cup and there is thrush outside, so beautiful on its pyre; so like millinery.

There is this hour, now, in the kitchen.

Clarissa will not die, not by her own hand. How could she bear to leave all this?

Virginia prepares to offer some wisdom about children. She scant idea what she'll say, but she will say something.

She would like to say, It is enough. The teacups and the thrush outside, the question of children's coats. It is enough.

Someone else will die. It should be a greater mind than Clarissa's; it should be someone with sorrow and genius enough to turn away from the seductions of the world, its cups and coats. (1998, p. 154)

Em outra passagem, Cunningham, baseado nos diários e cartas, fala das coisas que inspiram Woolf a escrever e do quanto está determinada a concluir Mrs.

Dalloway.

She will go to the theater and concert halls. She will go to parties. She will haunt the streets, see everything, fill herself up with stories.

...life; London...

She will write and write. She will finish this book, then write another. She will remain sane and she will live as she was meant to live, richly and deeply, among others of her kind, in full possession and command of her gifts (1998, p. 209).

Concluímos inclusive que é mérito de uma obra canônica ser escolhida para ser adaptada, prova que seu autor foi assertivo quanto aos acontecimentos, temas e personagens que escolheu. Entendemos que as grandes histórias merecem serem recontadas por muitos anos e por muitas gerações, por isso, o valor das adaptações. 
Alguns textos canônicos ficam de fora das discussões contemporâneas e se tornam textos datados por conta dos temas restritos a determinado grupo de leitores, acostumados a assuntos que não interessam tanto do ponto de vista comercial do mercado editorial. Não são por isso textos inferiores, mas sua leitura é restrita a certos grupos.

Mesmo assim, o que percebemos é certo receio da crítica literária com relação às adaptações. Parece que a crítica muitas vezes não aceita que uma obra canônica seja reescrita para preservá-la sob seu domínio e o desse grupo de leitores. Isso nos lembra, inclusive, o romance O nome da Rosa, de Umberto Eco (2009), coincidentemente outra narrativa que utilizou elementos adaptados. Nessa história, uma biblioteca que ficava dentro de uma abadia na Idade Média era protegida do público por membros da igreja. Isso acontecia porque algumas obras dessa biblioteca eram consideradas perigosas para o destino da própria igreja católica e, mais ainda, do grande público. É como se a mensagem interpretada fosse: o conhecimento pode trazer consequências terríveis e por isso vamos fazer essa seleção do que pode e do que não pode ser conhecido pelo mundo. Esse pensamento medieval parece tolher qualquer direito à interpretação do público leitor.

Talvez a crítica não acredite ou não concorde com as releituras de obras canônicas (adaptações) por julgar que ninguém, exceto ela, poderia extrair a interpretação correta daquela obra, embora sabendo que as interpretações de uma obra literária são diversas. Defendemos a citação correta das fontes em obras adaptadas, inclusive para preservar as questões jurídicas relacionadas ao mercado editorial, mesmo no caso de adaptações que usaram argumento de obras em domínio público. Não consideramos um problema o autor (ou autores) do(s) texto(s)fonte não figurar(em) na capa do livro, desde que se façam presentes de forma 
declarada em alguma parte da obra. Agora, quanto a escolher o que pode ou não pode ser interpretado por adaptadores contemporâneos é considerado por nós uma verdadeira ditadura da crítica literária, muitas vezes tão elitista quanto a própria posição de Virginia Woolf diante de alguns assuntos.

Outros nomes, como o Evans de Mrs. Dalloway, também foram adaptados por Cunningham. Temos em The Hours o Evan, marido de Walter Hardy, amigo de Clarissa Vaughan que ela encontra no trajeto até a floricultura. Cunningham aproveita a descrição dessa personagem para fazer outra apropriação: criticar a obsessão de muitos gays com relação à jovialidade e a forma física, outro tema bastante político e contemporâneo.

Outro fato que atualiza a obra é a menção ao estado de saúde de Evan, que também está com AIDS. Ele se sente melhor por causa do novo coquetel de medicamentos que estava tomando. Aqui Cunningham aproveita para mostrar a possibilidade de reconstrução de uma vida diante de problemas graves. Existem três possibilidades em The Hours: o desistir e fugir (Laura Brown), o desistir e matar-se (Virginia Woolf e Richard) e o lutar enquanto é possível (Evan).

As intertextualidades não param por aí: o ano 1923 (em que se passa Mrs. Dalloway de Virginia Woolf) aparece em The Hours de Cunningham. É o ano em que a hisória de Woolf é retratada pelo autor americano. Até o mês do ano (junho) é compilado: em Mrs. Dalloway a história de Dalloway se passa em "this moment of June" (p. 6) e em The Hours Cunningham, ao falar de Vaughan nos anos 1990, diz "What a thrill, what a shock, to be alive on a morning in June" (1998, p. 10) grifo nosso). As datas, portanto, também interessam a Michael Cunningham a ponto de 
serem reproduzidas em The Hours. Essas reproduções mostram uma tentativa de propor maior a interação com a obra woolfiana.

A personagem Mrs. Dalloway de Woolf (1925) é reconfigurada em Laura Brown e Clarissa Vaughan. O primeiro capítulo de The Hours "Mrs. Dalloway" é um capítulo de apresentação da personagem Clarissa Vaughan, cujas intenções nos remetem à Mrs. Dalloway de Woolf. Em Mrs. Dalloway (1925) o narrador, falando de Clarissa Dalloway, diz "she, too, was going that very night to kindle and iluminate; to give her party" (p. 7). Acontece que a Mrs. Dalloway de Cunningham (Clarissa Vaughan), também vai dar uma festa, conforme podemos ver a seguir:

Tonight she will give her party. She will fill the rooms of her apartment with food and flowers, with people of wit and influence. She will shepherd Richard through it, see that he doesn't overtire, and then she will Escort him uptown to receive his prize (1998, p. 13).

O trecho acima também introduz o personagem Richard em The Hours, com quem Clarissa Vaughn compartilha uma amizade e uma história de amor do passado. Richard é o nome do marido de Clarissa Dalloway em Mrs. Dalloway. Em The Hours, temos ainda Sally, agora representando a esposa de Clarissa Vaughan.

Mas Cunningham inovou também através de suas próprias ideologias trabalhadas em The Hours. O leitor contemporâneo desse romance, longe das discussões sobre obra adaptada ou original, aceitou essas apropriações e as recebeu muito bem. Isso ocorre, conforme podemos concluir pelo aspecto de ineditismo. Além de citações diretas de trechos de Mrs. Dalloway nos capítulos intitulados Mrs. Brown, percebemos ainda adaptações de outros personagens e incidentes em vários momentos da obra. A personagem Laura Brown está lendo o romance Mrs. Dalloway e, em diversos momentos, cita trechos dessa narrativa e 
reflete sobre ela. Parece ainda dialogar com uma espécie de prefácio da obra ao se referir com frequência ao suicídio de Woolf. Chega mesmo a se inspirar na ideia e tenta dar fim à própria vida, talvez pelo personagem Septimus Smith de Mrs. Dalloway, talvez pela própria Woolf.

O estudo de Sanders (2006, p. 115-9) sobre as adaptações e apropriações de Cunningham em torno do romance Mrs. Dalloway configura uma boa gama de exemplos que refletem o processo de criação do escritor a partir da leitura dessa obra. Ela reitera a ideia de que Cunningham repete frases de Mrs. Dalloway em The Hours como uma espécie de refrão (riff) para continuamente lembrar o leitor do quanto esse romance importa para as personagens apresentadas, em especial a Laura Brown.

Também, conforme já afirmamos, imita o fluxo de consciência woolfiano através da proposta de capítulos alternados, sendo a maior parte deles dedicada a Clarissa Vaughan (quatro capítulos, de um total de doze) e Laura Brown (três capítulos, de doze). Reproduz ainda o suicídio do personagem Septimus Smith através do suicídio de Richard.

Sobre isso, a pesquisadora Sanders destaca um dado importante: The Hours começa com o suicídio de Woolf e termina com o de Richard, o que nos remete a um movimento circular ou de repetição e aproximação com a obra de Woolf. Sanders (2006, p. 118) confirma esse aspecto:

Cunningham updates Woolf' novel in successive movements through his triptych of characters in the temporal, geographical, and cultural manner which we have already identified as a common factor to these 'movements of proximation. 
Há outras adaptações desse tipo: Clarissa se casa com Richard em Mrs. Dalloway e com Sally em The Hours, o que também faz alusão ao relacionamento entre Vita Sackville-West e a própria Woolf ou entre Clarissa e Sally Seton. O estudo de Sanders prossegue explicando, de forma mais analítica, a proposta principal de apropriação de Cunningham diante da obra woolfiana: usar um tema de grande repercussão na atualidade. Em Mrs. Dalloway, Woolf falou da Primeira Grande Guerra e, no último volume de suas Cartas (1982) da Segunda Grande Guerra. Em ambos os casos, ela fala sobre quantas vidas são perdidas, do quanto esses acontecimentos provocam dor e desestabilizam a mente dos homens. Em The Hours, o tema provocante escolhido por Cunningham é a AIDS, sabendo que, pelo menos até os anos 1990, tanto as Guerras quanto essa doença mataram em grande quantidade. O personagem de Cunningham de nome Richard é gay e está com AIDS nos anos 1990. Sanders acrescenta (p. 117) à esse respeito:

Cunningham's personal sexual politics, as well as his obvious feminist sympathies, inform his particular appropriation of Mrs. Dalloway. This is an appropriation informed as much by late twentieth century queer politics and theory as it is by its feminist and postmodern counterparts.

A intenção de Cunningham ao discutir uma temática tão impactante quanto a da AIDS mostra o grau de comprometimento desse escritor com a proposta de adaptação de uma escritora canônica que também se referiu a um tema importante de sua época (a Guerra). Essa escolha também serve para o autor rememorar o cenário em que escreveu e publicou seu próprio trabalho (anos 1990), visto que essa foi a década em que muitos homens se descobriram doentes de AIDS, mas também foi o período em que a ciência fez muitas descobertas com relação à doença. 
O mundo acompanhou de perto a depressão nos anos 1990 causada pelo sofrimento, dor e morte de diversas personalidades tanto famosas quanto comuns que sofreram de AIDS. Muitas delas se sentiam impotentes diante da doença. Isso aconteceu na sociedade num todo, e na medicina, em particular, embora de forma velada. Acreditamos que, especialmente nos anos 1990, havia uma catarse social quase que generalizada de pessimismo com relação à AIDS. A sociedade tratava seus pacientes como incuráveis e fadados a morrerem. Os doentes, então, ficavam frequentemente deprimidos pela falta esperança de uma sobrevida maior, acelerando a progressão da doença.

Esse pressuposto lembra muito bem a forma como a personagem Richard de Cunningham vê a doença. Richard acaba deprimido por não ver esperança de cura ou melhora e opta pelo suicídio. Surgem nessa época os primeiros coquetéis, fato que não foi ignorado por Cunningham em The Hours, porém muitos anos ainda seriam necessários para que as pessoas do mundo todo parassem de olhar a AIDS como uma doença fatal e acreditassem na força dos remédios e tratamentos para o seu controle.

O comportamento de Richard diante da AIDS e dos médicos lembra ainda a forma como Woolf e a medicina tratavam seus transtornos mentais desde os anos 1920 até a década de 1940, quando veio a falecer. Woolf passou pelos melhores médicos da Inglaterra, mas não acreditava que algum deles poderia salvá-la. As visões, vozes, dores de cabeça, a depressão e os pensamentos de morte a acompanharam até o dia de sua morte. Não houve remédio ou terapia que a curasse de tudo isso. Aliás, muitos médicos não levavam a doença de Woolf a sério, assim como fez o Dr. Holmes com relação aos problemas psicológicos de Septimus Smith em Mrs. Dalloway. 
Smith também não acredita que os médicos pudessem curá-lo de seus problemas psicológicos. Em The Hours, Richard age da mesma forma. Esses personagens refletem na verdade a descrença da própria escritora inglesa quanto ao avanço da medicina nesse campo particular: tratar os problemas de uma mente inquieta, entediada, infeliz e angustiada com a vida que leva, seja por um problema de saúde, seja pela Guerra. É como se Cunningham quisesse resgatar essa discussão inicialmente proposta por Woolf: como conter ou curar os problemas da mente? Como aquietar os próprios pensamentos? Interrogações que valem para a contemporaneidade, visto que não há um consenso de cura total e definitiva para desordens relacionadas à mente humana. Atualmente fala-se no máximo em controle e isso deve ser feito por um longo período ou por prazo indeterminado.

Por fim, utilizar a temática da AIDS foi a forma encontrada por Cunningham para chamar a atenção do leitor contemporâneo para discutir assuntos tratados como grandes tragédias em seu tempo, como as Guerras foram no tempo de Woolf. Utilizando acontecimentos mais recentes, Cunningham imagina fazer com que o leitor contemporâneo conclua que em cada época há males de naturezas diversas que afligem a mente do ser humano e causam grandes repercussões.

\subsection{Homossexualidade em The Hours, nos Diários e nas Cartas}

Acreditamos que, de forma mais direta, foram as Cartas (1982) - em especial, as de amor para Vita Sackville-West - e depoimentos nos Diários (1980) que inspiraram a proposta de trabalhar o desejo homossexual particular da personagem Virginia Woolf de forma mais aberta em The Hours, o que nos remete novamente ao conceito de "apropriação" de Sanders (2006). 
Woolf tratou dessas questões de forma sutil em alguns de seus romances através de personagens, em Mrs. Dalloway: a paixão de Clarissa Dalloway por Sally Seton e de Septimus Smith pelo amigo Evans. O próprio Cunningham, em entrevista sobre a influência do trabalho dessa escritora para sua carreira (2011a), ressalta esse aspecto. Não há qualquer interação sexual entre personagens dos trabalhos de Woolf e apenas duas cenas de beijo, sendo uma delas em Mrs. Dalloway (1925). Mas, o que importa é que em seus romances e contos, Woolf jamais se referiu à própria sexualidade ou ao desejo homossexual da forma como Cunningham a apresentou em The Hours.

Então, como forma de revelar esse aspecto particular da escritora, Cunningham criou uma passagem em The Hours em que Woolf beija a própria irmã, Vanessa Bell, na boca. Tudo acontece em uma tarde em que Woolf havia convidado a irmã e os sobrinhos para uma visita em sua casa. Vanessa se antecipa no horário marcado, e Virginia a recebe com surpresa por ainda não estar pronta para sua chagada. Mesmo assim, ela demonstra alegria ao vê-la. Embora a sequência da narrativa não mostre qualquer susto ou retaliação por conta desse ato encabeçado por Woolf (as duas depois conversam sobre outros assuntos), pode certamente revelar ao leitor um desejo oprimido da personagem Woolf, não pela irmã, mas pelas mulheres. Apresentamos esse trecho de The Hours (1998, p. 114) para conferência:

\footnotetext{
Vanessa is her ship, her strip of green coastline where bees hum among the grapes.

She kisses Vanessa, chastely, on the mouth.

'Darling', says Virginia, holding her sister's shoulders in her hands. "If I tell you I'm enchanted to see you now, I'm sure you can imagine how ecstatic l'd have been to see you at the hour you were actually expected".

Vanessa laughs. $[\ldots]^{38}$
}

\footnotetext{
${ }^{38}$ Vanessa é seu navio, sua faixa de litoral verdejante, onde as abelhas zumbem entre as uvas.

Ela beija Vanessa, castamente, na boca.

"Querida", diz Virginia, segurando a irmã pelos ombros. "Se eu lhe disser que estou encantada em vêla agora, tenho certeza de que há de imaginar o quão extática eu ficaria em vê-la na hora marcada."
} 
Também percebemos que a fala de Cunningham nessa mesma entrevista (2011a) o direcionou a criar uma segunda cena de intimidade entre personagens femininas em The Hours e, assim, repetir a mesma marca de Woolf em toda sua obra, como ele mesmo afirmou. Baseando-se na mesma temática, a do desejo por pessoas do mesmo sexo, ele também confere à personagem Laura Brown um momento de carência, atração ou misto de sentimentos que culmina em um quase beijo gay com sua vizinha Kitty. Isso ocorre em um dos capítulos intitulados Mrs. Brown em que Laura conversa com Kitty, ouvindo-a e consolando-a, atenta à sua tristeza e apreensão por conta de uma cirurgia que fará em breve. No entanto, Kitty demonstra certo desconforto com esse ato e se afasta. Mesmo assim, o trecho mostra que o desejo das personagens naquele momento era recíproco (1998, p. 110):

Kitty nods against Laura's breasts. The question has been silently asked and silently answered, it seems. They are both afflicted and blessed, full of shred secrets, striving every moment. They are each impersonating someone. They are weary and beleaguered; they have taken on such enormous work.

Kitty lifts her face, and their lips touch. They both know what they are doing. They rest their mouths, each on the other. They touch their lips together, but do not kiss.

It is Kitty who pulls away.

'You're sweet,' she says.

Laura releases Kitty. She steps back. ${ }^{39}$

\footnotetext{
Vanessa ri. (1999, p. 95)

${ }^{39}$ Kitty faz que sim, a cabeça encostada nos seios de Laura. A pergunta foi silenciosamente feita e silenciosamente respondida, ao que parece. São ambas mulheres atormentadas e abençoadas, cheias de segredos partilhados, empenhando-se sempre. Uma e outra fazendo-se passar por alguém. Estão extenuadas e cercadas; assumiram uma tarefa tão imensa.

Kitty ergue o rosto e seus lábios se tocam. Sabem ambas o que estão fazendo. Descansam a boca, uma na outra. Os lábios se tocam, mas não chegam a se beijar.

É Kitty quem se afasta.

"Você é um amor", ela diz.

Laura solta Kitty. Recua. (1999, p. 92)
} 
Esse apelo homossexual feminino constante em The Hours certamente se baseou na biografia de Woolf e em seu possível desejo/relacionamento com Vita Sackville-West. Cunningham, como escritor contemporâneo e, nesse caso, leitor de biografias sobre Woolf, não ignorou em The Hours um constante debate: o da homossexualidade da escritora e de seus possíveis amantes. Ele por vezes reforça a natureza gay e infiel de Woolf em passagens que jamais apareceram em seus romances, mas que ficam muito claras em The Hours, nos Diários (1980) e nas Cartas (1982). Vejamos como exemplo uma das cartas a endereçadas Vita Sackville-West, dessa vez em 30 de agosto de 1940. Vita é apontada em biografias como as de Lee (1997) como uma amante de Woolf.

l've just stopped talking to you. It seems so strange. Its perfectly peaceful here - theyre playing bowls - l'd just put flowers in your room. And there you sit with the bombs falling round you. What can one say - except that I love you and I've got to live through this strange quiet evening thinking of you sitting there alone.

Dearest - let me have a line - let us meet next week. But one can scarcely bear it. Only we must. Yr loving V.

You have given me such happiness. (1982, p. 434)

Em outra passagem, agora do seu diário (1980, p. 313) do dia 15 de setembro de 1924 (segunda-feira), Woolf volta a confessar que gosta de Vita e que sua presença lhe faz bem.

Here I am, peering across Vita at my blessed Mrs. Dalloway; \& can't stop, of a night, thinking of the next scene, \& how l'm to wind up. Vita, to attempt a return, is like an over ripe grape in features, moustached, pouting, will be a little heavy; meanwhile, she strides on fine legs, in a well curt skirt, \& tough embarrassing at breakfast, has a manly good sense \& simplicity about her which both L. \& I find satisfactory. Oh yes, I like her; could tack her on to my equipage for all time; \& suppose if life allowed, this might be a friendship of a sort.

Concluímos que a inspiração de Cunningham para caracterizar a personagem Woolf em The Hours passou pela leitura das cartas de Woolf a seus amantes, em especial a Vita Sackville-West. As personagens principais que vivenciam experiências gays de The Hours - Virginia Woolf, Clarissa Vaughan e Laura Brown 
(em maior ou menor intensidade) - são na verdade "refrações" da própria Virginia Woolf segundo a interpretação de Cunningham. Sobre Laura Brown, segundo nossa conclusão, imaginamos inclusive ela que possa ter realizado as experiências amorosas com mulheres as quais ficaram reprimidas enquanto era casada em Los Angeles nos anos 1940. Ela foge, abandonando o filho Richie (Richard) para viver no Canadá e volta ao final da narrativa para seu velório. Nada é relatado sobre sua vida pessoal no período entre os anos 1940 até e seu encontro com Clarissa Vaughan. Inferimos que essa fuga possa ter servido a esse propósito. Clarissa Vaughan também concretiza os desejos de Woolf ao se casar com Sally.

Por fim, percebemos que em The Hours Cunningham dispensa o mesmo tratamento romântico a essas três personagens. Novamente, não há cenas de sexo. Contudo, há momentos de desejo, certas atitudes, pensamentos e cenas de beijo (envolvendo algumas dessas personagens) que evidenciam de forma mais clara 0 desejo homossexual que povoa de forma constante esse romance. 


\section{CAPÍTULO 3 - A REESCRITA DA OBRA DE VIRGINIA WOOLF NO BRASIL}

Levando em conta a repercussão que The Hours (1998 e 2002) ${ }^{40}$ causaram no mercado editorial de vários países (entre agentes literários e público leitor), chamamos a atenção para a valorização da literatura woolfiana no Brasil. Nesse ponto, "refrações" de The Hours, como a tradução feita por Beth Vieira, publicada em 1999 pela Companhia das Letras, apenas um ano após o lançamento do original, e também a veiculação do filme em circuito nacional, a partir do ano de 2002 , merecem destaque. Foi a partir desse momento que verificamos uma constância nas reedições de romances e contos de Woolf, bem como a publicação de alguns trabalhos inéditos, além de biografias e trabalhos correrlatos nunca antes vista. A partir de então, a publicação de obras de Woolf recebeu no Brasil maior atenção por parte das editoras no período que sucedeu o lançamento da tradução "As Horas" (1999) - e do filme homônimo (2002) -, afirmação essa feita com base em pesquisa de nossa autoria (CARIBÉ, 2011).

Contudo, a maior pesquisa antológica sobre as traduções de Woolf no Brasil está no blog da tradutora Denise Bottmann (2013) e no romance de Antonio Bivar (2005). O blog de Bottmann traz inclusive dados sobre a publicação dos contos e ensaios de Woolf no Brasil, que aconteceu de maneira bastante inexpressiva e sazonal em coletâneas até, pelo menos, 1999. A publicação dos romances de Woolf no Brasil até 1999 seguiu o mesmo padrão da publicação de seus contos. Esse pouco interesse prévio à publicação de As Horas e do lançamento do filme homônimo se constituiu no "gatilho" para as algumas das conclusões que apresentamos nesta pesquisa.

\footnotetext{
${ }^{40}$ Livro e filme, respectivamente.
} 
O romance de Bivar relata as experiências do escritor paulista Antônio Bivar, membro da The Virginia Woolf Societty of Great Britain (2014), com viagens para a Inglaterra, a leitura da "obra" de Woolf, as pesquisas sobre o Bloombury Group, as cartas trocadas com Quentin Bell (1910-1996) ${ }^{41}$ e os festivais literários que participou, tenho inclusive assistido palestras de Michael Cunningham sobre a obra woolfiana. Bivar é referência no assunto, tendo inclusive escrito prefácios e pósfacios para algumas edições de romances de Woolf publicados na atualidade, como é o caso de Noite e dia (2011), reedição publicada pela editora Novo Século.

Os dados que ora apresentamos foram compilados dessas duas fontes que tomamos como referência pela credibilidade de seus autores no mercado da tradução e da literatura no Brasil. Interessa-nos particularmente a primeira edição de cada romance de Woolf publicado em língua portuguesa. Assim, as datas que apresentamos se referem ao ano em que aquele romance de Woolf foi editado no Brasil pela primeira vez. Citaremos também as reedições mais importantes, especialmente aquelas publicadas nos períodos anterior e posterior a 1999, ano da publicação de As Horas, tradução do romance de Michael Cunningham.

As primeiras traduções dos romances de Woolf no Brasil só foram publicadas nos anos 1940, período que chamaremos de Primeira Fase de traduções. Seu primeiro romance a ser publicado em língua portuguesa foi exatamente Mrs. Dalloway, traduzido em 1946 pelo já reconhecido escritor gaúcho Mario Quintana para a Editora Globo (antes dela, houve apenas a publicação de um conto, em 1942). Essa tradução foi republicada pela editora Nova Fronteira em 1980 e em 2006. A primeira fase de lançamento dos romances de Woolf no Brasil continua em 1946, quando foi publicado As Ondas pela editora Revista dos Tribunais, com

\footnotetext{
${ }^{41}$ Sobrinho de Virginia Woolf, casado com a editora dos diários de Woolf, Anne Olivier Bell.
} 
tradução de Sylvia Azevedo. Em seguida, em 1948, foi publicado Orlando pela Editora Globo, com tradução de Cecília Meireles, encerrando a primeira fase de publicação dos romances woolfianos no Brasil. Vejamos um resumo dessas informações na tabela a seguir.

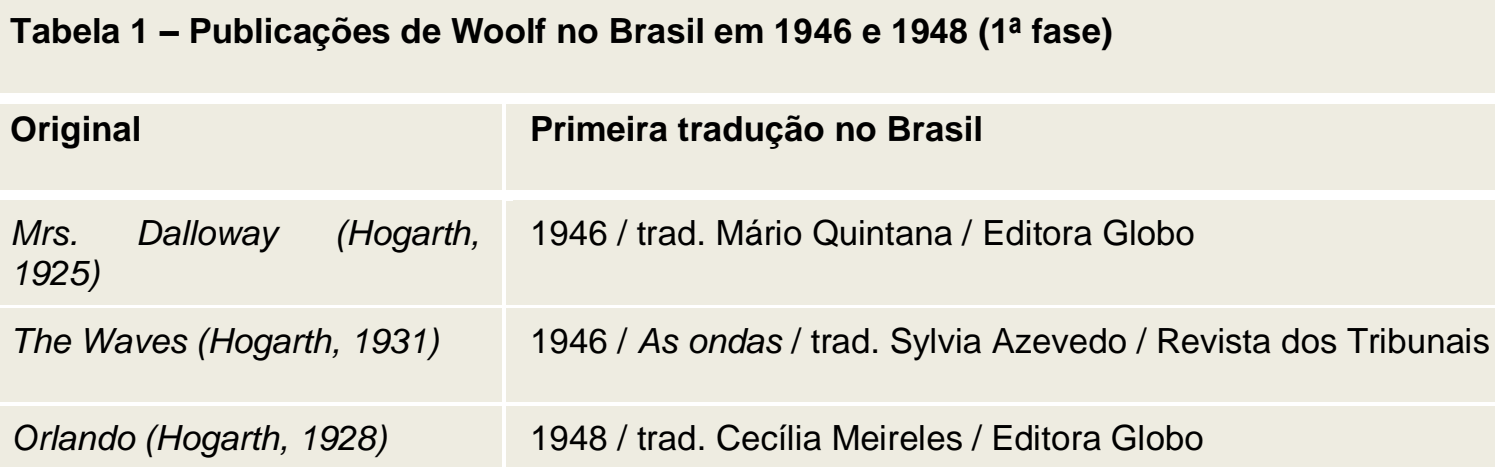

Nessa primeira fase (e também na segunda) era comum para as editoras nacionais contratarem escritores brasileiros já reconhecidos no mercado nacional por seus romances e poemas. Assim, Quintana e Meireles foram convidados para apresentarem as primeiras obras de Woolf em língua portuguesa. Isso ocorreu por vários motivos, mas o principal deles é que, segundo Halewell (2005), a maior parte dos romances canônicos das literaturas inglesa, norte-americana e francesa só foi traduzida e publicada em língua portuguesa pela primeira vez a partir dos anos 1940. Então esses escritores canônicos estrangeiros precisavam ser inicialmente apresentandos ao grande público leitor do Brasil. O papel de Meireles e Quintana foi, dessa forma, fundamental. Os lançamentos de Mrs. Dalloway (1946) e de As Ondas (1946) também serviram como teste para mensurar o grau de aceitação do público para com a literatura woolfiana no Brasil.

Outro ponto que nos chama a atenção sobre as traduções de Woolf diz respeito ao nome dado ao romance Mrs. Dalloway no Brasil. Aqui, o livro foi batizado 
desde sua primeira edição com o mesmo nome da edição inglesa, mantendo o pronome de tratamento Mrs. do título original (quando poderia ter sido traduzido como Senhora Dalloway), sendo sua personagem principal tratada dessa forma durante todo o enredo. Entendemos que essa foi uma forma de "apropriação" (SANDERS, 2006) do nome original, pois certamente a editora levou em conta todos os aspectos que permeiam uma obra reconhecida mundo afora por críticos literários e pelo público. Assim, ela provavelmente julgou que não seria conveniente traduzir ou adaptar também o título para a língua portuguesa. Cunningham (1998) seguiu a mesma tendência de "apropriação", batizou seu romance com o título que Woolf daria a Mrs. Dalloway: The Hours.

Um segundo momento de traduções compreende a publicação de todos os outros romances de Woolf em Língua Portuguesa. Esse período vai de 1968, ano em que foi publicada a primeira edição de $O$ farol, traduzido por Luiza Lobo e publicado pela Gráfica Record, até 1993, quando foi publicado $A$ viagem, traduzido por Lya Luft para a editora Siciliano. Luft traduziu também O quarto de Jacob (1980) e Entre os atos (1981), ambos publicados pela Nova Fronteira, mesma editora que publicaria as traduções de Raul de Sá Barbosa para os livros Noite e dia (1979) e Os anos (1982). Luft também já era uma escritora reconhecida no mercado brasileiro. Seus romances são biográficos e ela com frequência reproduz o fluxo de consciência woolfiano em obras como Perdas e ganhos (LUFT, 2004). Certa vez, Luft declarou em entrevista (2008) que se sentia honrada por ter traduzido alguns dos principais romances de Woolf para a língua portuguesa, mas que aquela foi uma tarefa das mais desafiadoras. Ela é até hoje a escritora brasileira que mais traduziu os romances de Virginia Woolf, somando três no total. Apresentamos uma tabela onde constam os principais dados desse período: 
Tabela 2 - Publicações de Woolf no Brasil de 1976 a 1993 (2a fase)

Original

To the Lighthouse (Hogarth, 1927)

Night and Day (Duckworth, 1919)

Jacob's room (Hogarth, 1922)

Between the acts (Hogarth, 1941)

The years (Hogarth, 1937)

The voyage out (Duckworth, 1915)

Nessa segunda fase, também começam as reedições de algumas obras de Woolf. Em 1976, temos o lançamento de Passeio ao farol (1976) pela editora Labor com tradução de Oscar Mendes. Depois, temos a primeira reedição de Mrs. Dalloway, feita em 1980 pela Nova Fronteira, e duas reedições de Orlando (1978 e 1994). Apresentamos tabela ilustrativa sobre as primeiras reedições de Woolf.

\section{Tabela 3 - Reedições de Woolf no Brasil de 1976 a 1993 (2ª fase)}

\section{Original}

To the Lighthouse (Hogarth 1927)

Orlando (Hogarth, 1928)

Mrs. Dalloway (Hogarth, 1925)

The Waves (Hogarth, 1931)

Orlando (Hogarth, 1928)

\section{Reedições}

1976 (reedição) / Passeio ao farol / trad. Oscar Mendes (Labor) 1978 (reedição) / Orlando / trad. Cecília Meireles / Nova Fronteira

1980 (reedição) / Mrs. Dalloway / trad. Mário Quintana / Nova Fronteira 1980 (reedição) / As Ondas / trad. Lya Luft / Nova Fronteira 1994 (reedição) / Orlando / trad. Laura Alves / Ediouro 
Além do que apresentamos na tabela anterior, verificamos que foi publicada a edição já citada de Os diários de Virginia Woolf (1989) pela Companhia das Letras, com tradução e edição de José Antonio Arantes. Outras biografias importantes de Woolf, como a de John Lehmann (1989), também foram lançadas nessa mesma época no Brasil.

A partir da terceira fase fica clara a influência da publicação de As Horas (1999) no mercado editorial brasileiro. Ressaltamos a publicação da coletânea Contos Completos (2005), pela editora Cosac Naify. Podemos conferir esses dados na tabela que apresentamos logo abaixo.

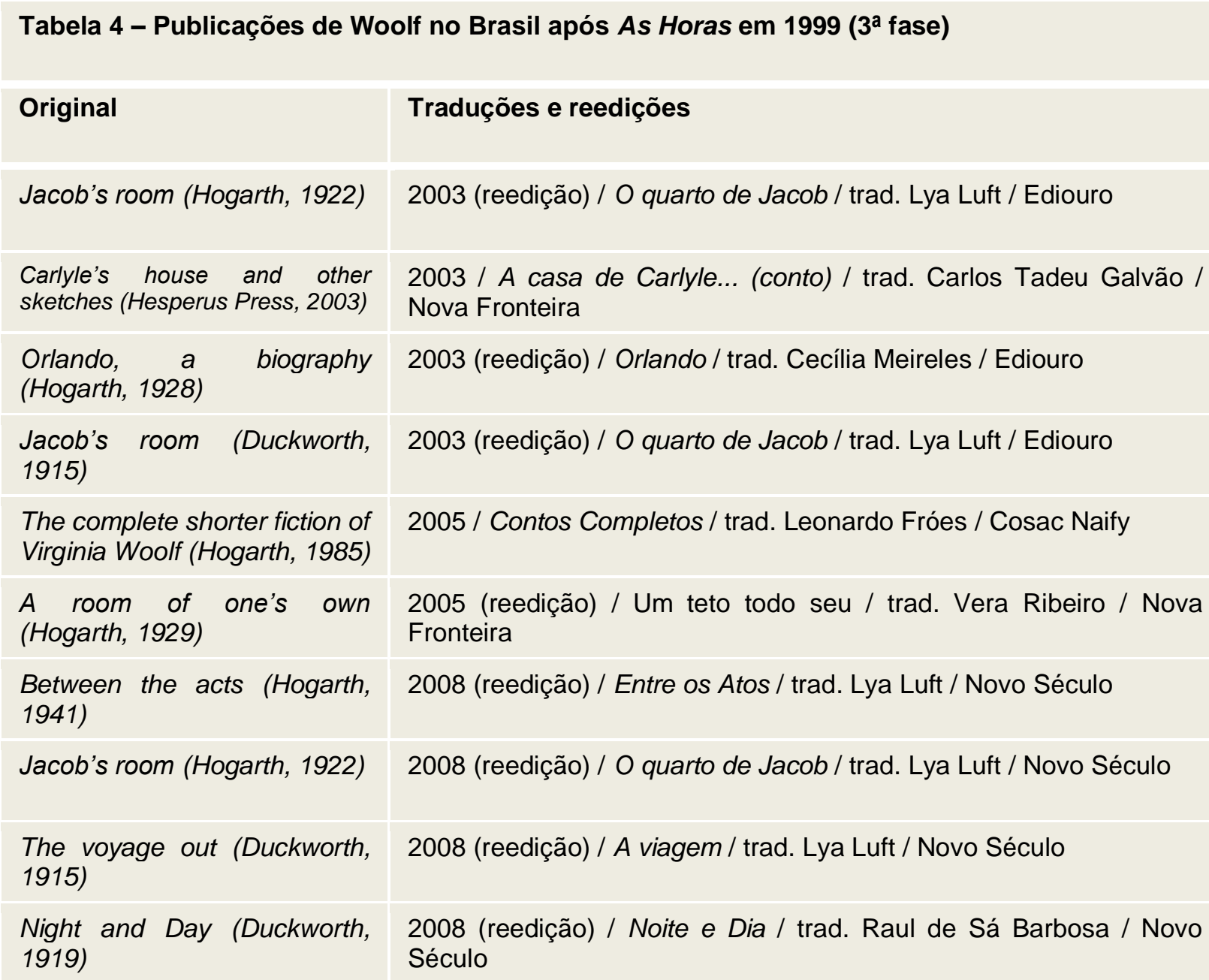


Sabemos que, além do que mostrou a tabela anterior, tivemos o lançamento de várias biografias, a realização de diversos estudos acadêmicos e jornalísticos sobre Woolf, e, por fim, a reedição de todos os grandes romances e contos de Woolf no Brasil. No exterior, aconteceu ainda a reedição dos Diários e Cartas.

Antes da publicação de As Horas no Brasil, em 1999, apenas algumas coletâneas de contos da literatura universal (que continham um ou mais contos de Woolf) foram publicadas em períodos distintos, mas nada muito representativo. $\mathrm{O}$ trabalho de tradução de todos os contos de Woolf nessa terceira fase ficou a cargo do poeta e tradutor carioca Leonardo Fróes. Ele comentou essa experiência em um evento de tradução que aconteceu em 2009, no SESC Pompeia, em São Paulo. Nesse evento, Fróes, que costuma ser bastante reservado, recitou trechos dos contos e revelou sua predileção por Woolf e pelo uso do fluxo de consciência, que ele traduziu de forma bastante coerente, segundo nossa opinião. Esse dado também pode ser conferido pelo novo convite feito a ele em 2011 pela editora Cosacnaify para traduzir outra biografia de Woolf recém-lançada à época (MARDER, 2011). Sua tradução foi inclusive bastante elogiada por Bivar (2011) em resenha da obra publicada na época de seu lançamento no suplemento Sabático do Jornal O Estado de S. Paulo.

Ocorre que, depois do aniversário de 70 anos da morte de Woolf, em 28 de março de 2011, outras três editoras também publicaram Mrs. Dalloway em novas traduções no ano de 2012, uma vez configurado o domínio público de toda a obra de ficção da escritora. A editora Cosacnaify, situada na capital paulista, publicou Mrs. Dalloway traduzido por Claudio Alves Marcondes. Essa edição em particular foi recomendada pelo jornalista e crítico literário Vinicius Jatobá em resenha publicada no Jornal O Estado de São Paulo (2012). Nesse mesmo ano, a editora gaúcha 
L\&PM lançou outra tradução feita pela tradutora Denise Bottmann, que relata essa experiência de tradução em seu blog (BOTTMANN, 2013). Tivemos ainda a Atlântica (editora carioca), que lançou uma terceira tradução realizada por Tomaz Tadeu. Vejamos uma última tabela que reúne esses dados.

\begin{tabular}{|c|c|}
\hline Original & Reedições \\
\hline The Waves (Hogarth, 1931) & 2011 (reedição) / As Ondas / trad. Lya Luft / Novo Século \\
\hline The years (Hogarth, 1937) & 2011 (reedição) / Os Anos / trad. Raul de Sá Barbosa / Novo Século \\
\hline $\begin{array}{l}\text { Mrs. Dalloway (Hogarth, } \\
\text { 1925) }\end{array}$ & $\begin{array}{l}2012 \text { (reedições) / Mrs. Dalloway / Cosacnaify (Claudio Marcondes), } \\
\text { L \& PM (Denise Bottmann) e Atlântica (Tomaz Tadeu) }\end{array}$ \\
\hline $\begin{array}{l}\text { To the Lighthouse (Hogarth, } \\
\text { 1927) }\end{array}$ & $\begin{array}{l}2013 \text { (reedições) / Ao farol / trad. Tomaz Tadeu (Autêntica), Doris } \\
\text { Goettems (Landmark) e Denise Bottmann (L\&PM) }\end{array}$ \\
\hline $\begin{array}{l}\text { Orlando, } \quad \begin{array}{l}\text { a } \\
\text { (Hogarth, 1928) }\end{array} \\
\text { (Hography }\end{array}$ & $\begin{array}{l}2014 \text { (reedição) / Orlando / trad. Jorio Dauster / Penguin/Companhia } \\
\text { das Letras. }\end{array}$ \\
\hline
\end{tabular}

Talvez, motivadas pela configuração do domínio público sobre a obra de Woolf, editoras como Novo Século, L\&PM, Autêntica, Atlântica, Landmark e Penguin/Companhia das Letras passaram a publicar os principais trabalhos de Woolf. Algumas delas publicaram também ensaios feministas, como foi o caso da L\&PM (2012) e outros textos ainda inéditos em língua portuguesa.

Podemos concluir que, especialmente as reedições das traduções dos principais romances de Woolf lançadas no período posterior a 1999, revelam que o romance de Michael Cunningham, As Horas, influenciou de forma considerável o merdado editorial brasileiro quanto à obra woolfiana, por meio dos seus agentes de reescrita. Ao conhecerem o referido romance de Cunningham, esses agentes providenciaram a reedição dos trabalhos mais importantes de Woolf (seus romances), bem como de refrações diversas, como as traduções dos contos 
completos (2005) e até ensaios crtíticos (2012), além de biografias diversas que poderiam atrair novos leitores, especialmente os non-professional readers brasileiros.

As Horas reescreveu a obra de Woolf especialmente no mercado editorial brasileiro, conforme podemos conferir através dos dados apresentados. Todas as refrações dos trabalhos da escritora inglesa publicadas em anos posteriores a esse romance (traduções e adaptações diversas) foram lançadas com o objetivo de fidelizar o leitor brasileiro ao estilo woolfiano e aproveitando a nova visibilidade proporcionada pelo trabalho adaptativo e apropriativo de Cunningham. Esse trabalho, sem dúvida, resgata Woolf para alguns leitores brasileiros e a apresenta para tantos outros, inclusive para aqueles que buscam sua literatura após terem tomado contato com ela através de sua adaptação fílmica. Assim, afirmamos que o filme The Hours (2002) também reescreve a obra woolfiana aproveitando a transmidialidade entre literatura e cinema que influencia o mercado editorial há vários anos. 


\section{CONCLUSÃO}

Nesta pesquisa, trabalhamos com o conceito de "reescrita" de Lefevere (1999a) para falar de um processo que recomeçou em 1998 nos Estados Unidos, com a publicação do romance contemporâneo The Hours de Michael Cunningham e culminou com o lançamento do filme de mesmo nome em 2002. A obra ficcional de Woolf continuou circulando nos diversos "sistemas literários" (EVEN-ZOHAR, 1978, 1990) do mundo desde $1941,{ }^{42}$ ano de sua morte, até 1998 . Porém, isso só aconteceu graças a algumas tentativas de uma reescrita dessa obra em momentos pontuais e em determinados países/contextos por diversos agentes de reescrita, com vistas a promover um encontro dos romances e contos da escritora inglesa com o leitor contemporâneo.

Ocorre que, a partir do nosso entendimento desse conceito formulado por Lefevere como um processo contínuo e maior de reelaboração dos trabalhos de um escritor canônico para um cenário diverso daquele em que fora primeiramente editado - inclusive abarcando outros públicos leitores que não apenas os leitores profissionais -, arriscamos dizer que esses ciclos de reescrita anteriores a The Hours não resgataram de fato a obra de Woolf. Entendemos a reescrita dos livros de um escritor canônico no atual contexto editorial como algo que tenha necessariamente que possuir alcance global, sendo que Woolf passou alguns intervalos nos quais sua obra foi pouco explorada nesse exigente mercado editorial.

Sendo assim, cada vez que um livro de Woolf era reeditado, inscrevia-se uma nova tentativa de realocar a autora no cenário contemporâneo. Todas as "refrações" (LEFEVERE, 1982a e 1982b) de suas obras publicadas/veiculadas até 1998 - as

\footnotetext{
${ }^{42}$ Este também foi o ano da publicação do seu último romance, Between the acts.
} 
traduções dos seus romances e contos em outras línguas, suas reedições, os prefácios de algumas edições, as críticas em periódicos internacionais para esses trabalhos, a publicação de seus diários e cartas, algumas adaptações fílmicas, como Orlando (1992) e Mrs. Dalloway (1997), as biografias, os verbetes em antologias literárias sobre Woolf, as resenhas críticas de seus livros, etc. - também não foram suficientemente marcantes em termos de importância literária para promover o que consideramos ser de fato um processo de "reescrita" compatível com a obra de um escritor canônico. Ou ainda: essas refrações talvez não chegassem ao leitor contemporâneo. Era como se a obra ficcional da escritora inglesa, que circulava no mercado editorial até então, viesse sempre antes das refrações citadas e, de alguma maneira, isso não funcionou.

Não desmerecemos o trabalho desses profissionais da refração: tradutores dos romances de Woolf para outras línguas, os editores de suas cartas e diários (publicados durante os anos 1970 e 1980), diretores e roteiristas de filmes baseados em seus romances, biógrafos, críticos de literatura, tradutores, jornalistas, acadêmicos, etc., mas talvez durante esses os quase 60 anos desde sua morte até The Hours, seus romances ainda procurassem ser conhecidos de forma mais contextual com cada década. E isso não queria dizer tornar Woolf popular entre leitores profissionais e não profissionais (LEFEVERE, 1992a), mas sim, apenas torná-la atual, reconhecida, com a mesma força de fenômeno literário que teve durante o modernismo inglês. Entendemos que isso era possível, pois ela havia em seus escritos falado de muitos assuntos que dialogam com outros tantos até hoje (as Guerras, o papel da mulher na sociedade, o desequilíbrio emocional, etc.).

Inferimos que, nesse caso, pode ter havido divergência na forma de promover o encontro de Woolf com os mais variados leitores contemporâneos. O cenário cult 
evidenciado pelo grupo de intelectuais do Bloomsbury Group, do qual Woolf fazia parte, somado ao peso dos próprios ensaios críticos de Woolf sobre o modernismo inglês (2000a) e de sua proposta literária de se diferenciar com relação às formas narrativas, temas e discussões dos escritores de períodos anteriores (além da utilização do fluxo de consciência em seus romances e contos) foram fatores que, a nosso ver, talvez encaminharam a obra de Woolf para ser discutida sob uma visão intelectual, restrita a discussões acadêmicas e/ou jornalísticas. É como se essas "refrações" dialogassem somente com os leitores profissionais a quem Lefevere se referiu (1992a), excluindo os demais, leitores comuns, mesmo sendo esse grupo a grande maioria de leitores do mundo. Esses são os leitores que chegaram à obra de um escritor canônico, não através de vias acadêmicas, mas pela afinidade pela obra criada através do contato com suas refrações. O leitor comum ou o leitor da atualidade é atento às refrações de clássicos, sendo que muitos deles possuem apenas essas informações. Então, nesse caso, podemos afirmar que nenhuma das refrações citadas obteve ampla atenção do grande público, tampouco promovendo um amplo encontro com a obra ficcional primeira de Woolf.

O ano de 1998 marca a entrada de Michael Cunningham nesse cenário. Com certeza, tivemos, sim, todo o grupo de refrações relacionadas a Woolf citadas ao longo desta tese, e todos os profissionais que elaboraram essas releituras. Mas, quando falamos em um romance que seja uma proposta exclusivamente literária de reescrita do texto woolfiano em si - uma obra editorial ousada que se propusesse a isso - podemos afirmar que The Hours é um caso singular, a narrativa literária a de fato reescrever não apenas Mrs. Dalloway (1925), mas toda a obra de Virginia Woolf no contexto da atualidade. 
A partir da leitura de diversos textos de ficção e não ficção de ou sobre Woolf - e com apoio editorial e acadêmico para tanto - Cunningham elabora esse romance que dialoga com a sua imagem como escritora, com seu processo de criação e com a angústia de seus personagens, em suas fraquezas e imperfeições. Isso de fato "reescreve" a obra de Wolf no cenário literário internacional.

Conforme já apontamos, Cunningham já gozava de certo prestígio no cenário editorial americano, especialmente pelo reconhecimento de público e crítica ${ }^{43}$ de seus romances anteriores a The Hours - A home at the End of the World (1990) e Flesh and Blood (1995) -, conforme podemos conferir em diversos excertos citados nas páginas desses livros, no website do próprio escritor (WEBSITE DE MICHAEL CUNNINGHAM, 2014) e nas reedições desses romances no Brasil que permanecem até 2014 , o que já constata uma boa recepção pelo público leitor ${ }^{44}$. Nesse contexto, oferece The Hours para publicação pela mesma editora com que publicou esses trabalhos anteriores. Esse fato reverbera a ideia de "patronagem" de Lefevere (1992b). Esse conceito fala dos agentes envolvidos no processo de publicação de uma determinada obra e no quanto suas ideologias influenciam, por exemplo, as traduções. Vimos que Cunningham só pulicou The Hours porque obteve apoio de um determinado grupo editorial e também pela confiança dos críticos literários nos trabalhos anteriores desse autor/adaptador. Isso, sem dúvida, promoveu o encontro desse romance com o cenário literário internacional de forma incisiva e ampla, ou seja, bem diferente da forma como ocorreu em anos anteriores com as refrações citadas. Em suma, acreditamos que as indústrias literária e cinematográfica

\footnotetext{
${ }^{43}$ Reconhecimento que não pode ser comparado, logicamente, ao que o escritor obteve após o lançamento de The Hours (1998).

${ }^{44}$ Essa constatação reflete uma praxe das editoras: só se reedita uma obra literária quando ela tem boa circulação. Em outras palavras, apenas se uma certa quantidade de público estimada pela editora procura a obra é que ela é selecionada para reimpressão.
} 
americanas julgaram rentável e pertinente comercializar o livro The Hours e lançar o filme homônimo alguns anos depois.

Contudo, falando de forma particular do mercado editorial, concluímos que isso só aconteceu quando determinados patronos envolvidos no caso de uma reescrita da obra de Woolf perceberam o grau de influência das adaptações literárias no mercado contemporâneo dos anos 2010. Dizemos mais: a qualidade da obra adaptada que esperavam nesse caso precisaria se sobrepor à controversa classificação das editoras para um romance enquanto adaptação literária e, ao mesmo tempo, promover um diálogo com outros temas mais atuais.

Entendemos que especialmente o conceito de "apropriação" seja essencial nesse caso e no contexto literário internacional. Esse conceito é tratado com certo cuidado pela própria autora (SANDERS, 2006) ao se referir tanto aos textos-fonte citados em outros trabalhos de forma não convencional, quanto para as situações de uma narrativa que dá voz a personagens ou a temas que aparentemente não haviam sido explorados nesse texto, tudo isso baseado na interpretação e intervenção direta do adaptador contemporâneo. Michael Cunningham é um exemplo desse caso, que se apropriou de temas que lhes são particulares, como o homossexualismo, o feminismo e a crítica a determinadas atitudes sociais com relação ao comportamento das mulheres nos Estados Unidos do final dos anos 1940 e 1990, além da própria imagem da escritora inglesa Virginia Woolf nos anos1920 até sua morte.

São de fato as "apropriações" dentro de adaptações literárias ou em obras que apenas adaptam elementos de narrativas canônicas que dialogam com o leitor contemporâneo de forma incisiva e, de fato, reescrevem a obra de um autor 
canônico no cenário literário atual. Afirmamos isso porque, além de reelaborar as tendências vanguardistas dos escritores clássicos para formas narrativas e enredos mais pertinentes ao período literário em que são publicados, as apropriações introduzem o pensamento de um escritor contemporâneo que, identificado e apresentado ao leitor previamente (como foi o caso de Cunningham), atua como agente promotor de um diálogo entre o leitor e a obra. Esse fato mostra como um texto tido como canônico pode ser manipulado de forma a acolher ideias e contextos diferentes. Ele não é, portanto, findo, nem intocável, ao contrário, se interrelaciona com novos pensamentos, bastando que haja espaço para tanto. Podemos dizer que a qualidade de Cunnigham foi, em princípio, o fato dele ter aplicado o uso da intertextualidade em The Hours sem qualquer receio.

A proposta de apropriação desse autor foi delineada principalmente pelo cenário americano, no qual se passam as histórias de duas de suas personagens: Laura Brown (Los Angeles, anos 1940) e Clarissa Vaugham (Nova lorque, anos 1990). A história se passa em épocas nas quais as mulheres enfrentaram (e ainda enfrentam) inúmeras dificuldades com relação à livre expressão dos seus próprios desejos, não apenas os sexuais, mas todos aqueles que tocam a possibilidade de de realização de uma vida social, profissional e familiar da maneira que elas entendem com sendo a melhor para si.

A ponte usada por Cunningham para ligar essas duas personagens é a própria vida real de Virginia Woolf, mulher e escritora vivendo entre os anos 1920 e os 1940 na Inglaterra. Essa autora também trabalhou de forma introdutória assuntos como os citados acima em seus trabalhos de ficção e não ficção, questionando algumas posições machistas da sociedade inglesa em sua época. A identificação 
com as ideias da escritora sentida por Laura Brown, personagem que lê Virginia Woolf em The Hours, é um exemplo dessa ponte criada pelo autor.

De acordo com nossa leitura, que coincide com a de grande parte da crítica literária internacional, o romance The Hours se configura de forma a tornar personagens e temas woolfianos universais. Há uma clara tentativa do "adaptador" e "apropriador" Cunningham no sentido de trazer essa discussão para o cenário americano, seu contexto social e literário. $\mathrm{O}$ autor retrabalha a crítica à sociedade inglesa feita por Woolf através da escolha de um país estrangeiro (Canadá) como local para onde, ao final da obra, descobre-se que Laura Brown fugiu ao se recusar levar a vida que não a fazia feliz na América. Não deixamos de reconhecer e apontar traços de apropriação como este como responsáveis pelo que chamamos de boa recepção ao romance.

Outro ponto que consideramos de "apropriação" (SANDERS, 2006) é o da forma como a questão da sexualidade feminina é abordada por Cunningham em The Hours. O escritor trabalha a temática gay feminina de forma não velada em diversos momentos do romance. Primeiro, percebemos traços de um desejo ou carinho homossexual entre Virginia Woolf e sua irmã Vanessa Bell nos capítulos Mrs. Woolf, Com uma cena dentro desses capítulos terminando, inclusive, em um beijo entre as duas irmãs.

Cabe ressaltar que, apesar das evidências especialmente encontradas nas cartas a Vita Sackville-West, a escritora nunca declarou abertamente sua homossexualidade, tampouco mencionou qualquer desejo por sua própria irmã. Percebemos ainda em The Hours a vontade da escritora em fazer da personagem 
do romance Mrs. Dalloway - que escrevia à época - uma personagem com um desejo gay (o que de fato foi feito).

Em um segundo momento, Cunningham mostra Laura Brown e sua vizinha Kitty em outra cena de beijo. Para completar esse cenário de personagens gays femininas encontramos ainda Clarissa Vaugham, casada com Sally Seton, e a filha gay de Clarissa Vaughan, Julia, a qual, inclusive, adota um visual masculinizado, o que magoa sua mãe e desperta discussões relacionadas a esse tema. Temos ainda a namorada de Julia, Mary Krull, uma militante da causa gay.

Em suma, o desejo feminino gay parece tratado de forma livre. É como se a autocrítica de Cunningham, escritor pós-moderno e engajado com a causa gay, o direcionasse a essa abordagem, recorrente em trabalhos anteriores e posteriores a The Hours.

A predileção de Cunningham pela temática gay faz com que suas obras sejam amplamente discutidas também no âmbito da crítica literária feminista ou das teorias literária, lésbica e queer, assim como grande parte da obra de Woolf foi e ainda é. Thomas Bonnici (2007), em obra nacional de referência para a área das teorias feministas, é um dos pesquisadores a apresentar a escritora inglesa sob essa perspectiva. Internacionalmente, temos o trabalho de William Turner (2000), que discute abordagens feministas da crítica literária através de obras diversas, inclusive através das de Woolf.

Michael Cunningham, embora com publicações mais recentes, também está inserido no hall dos escritores que frequentemente discutem a temática gay. Trabalhos acadêmicos, literários e jornalísticos de caráter antológico, como os de Reed Woodhouse (Comtemporary Gay American Novelists, 1993), analisando 
trabalhos de Cunningham anteriores a The Hours já identificavam esse autor como representante desse grupo. Há ainda o importante trabalho de outro pesquisador americano Philip Gambone (Something Inside: Conversations with Gay Fiction Writers,1999). Tanto Woodhouse quanto Gambone colhem as opiniões do autor americano sobre seus próprios trabalhos à luz de algumas teorias gays e feministas de crítica literária com a intenção de problematizar essa discussão literária para uma repercussão no atual cenário social-político-ideológico gay da contemporaneidade.

Temos ainda o "Stonewall Book Award" - ou, como é mais conhecido nos Estados Unidos, "Gay, Lesbian, Bisexual and Transgendered Book Award" premiando The Hours na categoria ficção em 1999. Esse é um reconhecido prêmio internacional de literatura de temática LGBT. A premiação de The Hours nesse sentido só vem a confirmar o caráter ousado e, ao mesmo tempo, inovador da obra, por tratar da questão homossexual, inclusive envolvendo uma escritora canônica como personagem gay.

Cunningham aceitou esse prêmio, é claro, mas deixamos bem claro que em uma das edições pesquisadas - aquela impressa em 2002 -, há refrações importantes a serem discutidas nesse sentido. A refração que mais nos chamou a atenção é o fato da editora informar ao leitor dessa edição logo na capa que a obra ganhou o "Pulitzer Prize for fiction" em 1999 e na contra capa que a mesma obra também foi premiada com o "Pen/Falkner Award for fiction", dois prêmios de literatura reconhecidos mundialmente e de grande importância para o público leitor e também para a crítica literária especializada, porém aparentemente sem vinculação com nenhum segmento político. Nenhum desses prêmios categoriza a obra por seu conteúdo: apenas por sua qualidade como obra de excelência e que merece ser apreciada. Esses prêmios talvez sejam responsáveis por fomentar o jargão 
acadêmico/social/intelectual tão amplamente utilizado, qual seja "a boa literatura". Percebemos, porém, que não há qualquer referência impressa nessa edição ao "Gay, Lesbian, Bisexual and Transgendered Book Award". A partir desse fato concluímos que, no caso de The Hours, houve uma preocupação dos patronos editoriais e/ou de Cunningham de não rotular a obra ou de não direcionar a proposta de adaptação literária para um único cenário de discussão: a do enfoque gay.

A capa da edição de 2002 traz ainda uma fotografia relacionada ao filme The Hours (2002): as atrizes Merryl Streep, Juliane Moore e Nicole Kidman lado a lado, caracterizadas de Clarissa Vaughan, Laura Brown e Virginia Woolf, respectivamente. Essa refração é bastante utilizada comercialmente na literatura desde os anos 1990 do século $X X$ até a contemporaneidade, o que mostra que na há um canal de comunicação cíclico cada vez maior entre romances e adaptações fílmicas. A literatura hoje forma uma relação mercadológica com o cinema, gerando um constante movimento tanto de leitores que procuram os livros depois de assistirem suas adaptações para o cinema, como também de espectadores que procuram as livrarias depois de terem assistido a filmes adaptados de romances.

A utilização de fotografias de um filme nas edições literárias constitui, portanto, uma refração assertiva no âmbito da literatura pós-moderna. Essa relação de intercâmbio da literatura com outros meios e também de outros meios com a literatura na contemporaneidade é o que Hattnher (2013) chama de transmidialidade. Das relações entre a literatura e outros meios nascem adaptações de naturezas diversas.

No caso de The Hours o filme homônimo teve um papel fundamental. Segundo nosso entendimento o prestígio desse filme promoveu a reescrita da obra 
da autora canônica da forma como defendemos. Assim, o lançamento desse romance elogiado e premiado pelo mercado editorial e do filme foram fatores importantes para o processo de reescrita da obra de Woolf.

Reiteramos ainda outro elemento de apropriação em The Hours: a presença de personagens masculinos gays, como Richard e seu ex-amante, Louis W. A relação dessas personagens é explicada ao leitor em um dos capítulos dedicados a Clarissa Vaugham (capítulos intitulados Mrs. Dalloway). Esse núcleo gay do romance, formado por Clarissa, Sally, Julia, Mary, Richard e Louis forma um cenário de sexualidade gay tratada com mais abertura que parece advir da mesma proposta com que o autor tratou a sexualidade de Woolf e Laura Brown nos capítulos direcionados a essas personagens.

$\mathrm{Na}$ verdade, a linha narrativa de Cunningham parece ser sempre essa em The Hours: apresentar a trajetória de personagens que oscilam entre a hetero e a homossexualidade de forma natural, defendendo uma sexualidade não definida de forma a tornar as situações familiares e amorosas mais simples, mais comuns e mais importantes para o enredo. Essa naturalidade transparece inclusive na figura de Julia, filha de Clarissa Vaughan, em três exemplos: sua boa relação com Sally, sua madrasta, sua reação ao ser apresentada ao próprio Louis, ou ainda, na forma como ela se refere a Richard, amigo e ex-amante de sua mãe. Clarissa, embora não entenda o visual masculino de sua filha gay e tenha divergências ideológicas com Mary Krull, as respeita e, em princípio, parecem viver (mãe e filha) em considerável harmonia.

Assim, são as relações amorosas do passado e do presente desse núcleo que não são discutidas como relações gays por Cunningham, mas simplesmente 
como familiares, ora conflituosas, ora resolvidas, mas sem o peso de assim estarem/serem pelo fato de serem relações gays ou hétero. Então as adaptações literárias que incluem apropriações podem ampliar diretamente as discussões mais atuais nesse sentido através da influência direta dos seus autores.

Ocorre que Cunningham, homossexual assumido, por vezes declara não querer ou não se considerar um escritor de temática gay, ou exclusivamente gay (GAMES, 2002), sendo esse pensamento coerente com a linha que adota em seus romances. Temos ainda outra forte marca de apropriação do escritor Cunningham em The Hours: a presença do tema da AIDS, doença que levou o personagem Richard ao suicídio. Esse é um assunto que certamente conduz a discussão do romance para dentro das pretensões de Cunningham. A doença, surgida no início dos anos 1980, ainda fazia muitas vítimas quase vinte anos depois, sendo os homossexuais masculinos, durante muitos anos, as principais.

Até 1998, a literatura e o cinema já haviam retratado diversas histórias relacionadas à temática dessa grave doença. Contudo, Cunningham parece querer mostrar algo inédito. Ao resgatar a história de Woolf dentro da mesma narrativa, sendo ela vítima de depressão, dentre outros distúrbios psicológicos, o autor parece querer mostrar que em cada época existe um mal que aflige a humanidade. A depressão era ainda pouco estudada e compreendida pela própria medicina até os anos 1940, tanto na Inglaterra quanto em outras partes do mundo. Woolf, muitas vezes chamada de louca, se via desesperada pela forma como a doença dominava sua lucidez, seu humor e sua sanidade, conforme vimos em trechos de seus Diários (1980) e Cartas (1982). Ela então trabalhou a temática da depressão e da Primeira Grande Guerra através da personagem Septimus Smith em Mrs. Dalloway. 
Deprimido, especialmente no pós-Guerra, Septimus comete suicídio. Assim também o fizeram Richard, personagem em The Hours e Woolf, na vida real.

Hoje, nos anos 2010, a depressão é amplamente discutida no cenário médico internacional e há várias formas de tratamento. O número de casos também aumentou, mas existem normativas que auxiliam uma possível prevenção. Ocorre que o reconhecimento da doença de Woolf naquele tempo foi um fator social limitador para a escritora, para sua família e para o círculo social e intelectual que frequentava. O desconhecimento do problema fazia com que ela fosse taxada de louca. Esses transtornos ainda levam nos dias de hoje muitos de seus pacientes ao suicídio, como aconteceu com Woolf, em 1941.

Também ressaltamos um fator importante que diferencia a estratégia narrativa de Cunningham em The Hours: a depressão não foi descoberta pela medicina ou rotulada pela sociedade como uma doença gay, como erroneamente aconteceu no início da AIDS. Talvez, nesse aspecto, Cunningham tenha realmente preferido dialogar de forma mais direta com o leitor gay contemporâneo. Contudo, ele também falou ao heterossexual para que ao menos pensasse a respeito de uma situação ainda bastante comum ao final dos anos 1990 - a morte de milhares de pessoas, independetemente se sua orientação sexual, que ainda aconteciam pelo mundo todo. Dessa forma, concluímos, que a abordagem feita pelo autor sobre uma doença como a AIDS em The Hours parecia tão assertiva quanto o foram para Woolf a temática da depressão e da Guerra em Mrs. Dalloway (1925).

Em conjunto com essa apropriação (SANDERS, 2006), Cunningham segue resgatando Woolf em sua vida pessoal ao propor o mesmo destino da escritora inglesa ao personagem Richard: o suicídio. Esse aspecto do romance mostra, 
dialogando com muitos textos woolfianos, que uma mente aflita por causas diversas pode levar o indivíduo a desistir da própria vida. Com dito anteriormente, Richard funciona como adaptação do personagem Septimus Smith no romance Mrs. Dalloway (1925) trazida para The Hours.

Uma última passagem também reforça a temática do poder perturbador da mente nesse sentido: a tentativa de suicídio de Laura Brown, que aparentemente não sofria de doença alguma, a não ser de uma total insatisfação e angústia com a vida que ela vivia até então. Nesse caso, Brown, que desiste da ideia, mostra uma possibilidade de reconciliação com a vida. Ela abandona a família e foge em busca de sua libertação. O resultado disso é o fantasma criado na cabeça de Richard, seu filho, que cresceu com a presença/ausência perturbadora da mãe. Ele nunca se sentiu plenamente feliz com suas escolhas, porque sofria permanentemente com a ausência da mãe.

Brown também reaparece ao final da história, logo após o suicídio do filho, como alguém cheia de remorso. O destino dos personagens Brown e Richard parece mostrar ao leitor que toda ação resultante de uma mente inquieta, deprimida ou mesmo neurótica tem consequências terríveis para todos os lados, para o deprimido e para os que o cercam. Brown poupou sua vida, mas não conseguiu salvar a vida do filho. Sendo assim, Cunningham reitera a tese, também já proposta por Woolf em Mrs. Dalloway (1925), de que nossos pensamentos e atitudes, nossas ideias, sãs ou perturbadoras, são as geradoras de todos os nossos problemas.

Entendemos, por fim, que a intenção apropriadora de Cunningham não é levantar bandeiras em seus romances, mas apresentar histórias que conheceu e outras que ele criou em um cenário que ele acreditava estar se formando nos 
Estados Unidos dos anos 1990 e em muitos lugares do mundo: uma convivência literária mais aberta com as relações amorosas, sociais e familiares das pessoas, independente do gênero. Talvez Cunningham prevesse uma América ou um mundo com menos estereótipos e rótulos. Essa proposta em The Hours parte das relações vividas por uma escritora inglesa canônica e chega ao cenário contemporâneo pelas relações das personagens americanas Laura Brown e Clarissa Vaugham com outras personagens da narrativa.

Finalmente, enfatizamos que é urgente que a academia, a crítica literária e a indústria editorial revejam as adaptações literárias esob um olhar mais amplo e despido de preconceitos. Essas são narrativas que não podem mais ser citadas como inferiores ou de segunda mão em nenhuma dessas esferas de discussão. Afirmamos isso, pois, a adaptação literária como processo de composição ou como produto final não teria sobrevivido à Idade Média, passando pelo auge do romantismo inglês até a contemporaneidade com tamanha receptividade pelo público sem ter um valor próprio à parte da obra à qual ela se baseou. Reconhecer também o trabalho de adaptadores literários canônicos, como Chaucer e Shakespeare, e contemporâneos, como Cunningham, é entender que a literatura trabalha com adaptações de maneira natural. Adaptar é o caminho natural das narrativas, não a exceção.

Sanders (2006, p. 24) nos relembra ainda que o mais importante de tudo nessa discussão - para os críticos literários e acadêmicos - deveria ser o entendimento sobre o princípio do prazer na criação de adaptações. Nesse aspecto, os agentes literários deveriam entender que obras adaptadas prolongam o prazer conectado à memória, porque muitos leitores recorrem à boa memória de um texto anterior para apreciá-lo em uma nova proposta. Então, os processos de adaptação e 
apropriação na criação de obras literárias contemporâneas também precisam ser mais discutidos, pois são fundamentais e influenciam a literatura de modo positivo.

O romance The Hours reescreve a obra de Woolf no contexto atual porque encena principalmente o conceito pertinente de apropriação, indispensável para a apreciação de formas narrativas que trabalham com a ideia de adaptação. O leitor contemporâneo entende e aprecia as adaptações, intertextualidades, suplementações, alusões e reconhecimentos de outros textos anteriores, porém busca na ideologia do escritor-adaptador seu entendimento particular e propostas atuais para esse diálogo. 


\section{REFERÊNCIAS BIBLIOGRÁFICAS}

ADAPTATION, revista acadêmica. Disponível em: $<$ http://adaptation.oxfordjournals.org >. Acesso em 23 jun. 2014.

ALLEN, Graham. Intertextuality. Londres e Nova lorque: Routledge, 2000.

ALTMAN, Janet Gurkin. Epistolarity: approaches to a form. Columbus (E.U.A): Ohio State University Press, 1982.

ALENIUS, Marianne. The Letter: a genre for women. Artigo do website The History of Nordic Women's Literature, 2012. Disponível em: $<$ http://nordicwomensliterature.net/article/letter-\%E2\%80\%93-genre-women>.

Acesso em 22 abr. 2014.

AMORIM, Lauro Maia. Tradução e Adaptação: encruzilhadas da textualidade em Alice no país das maravilhas, de Lewis Carrol, e Kim, de Rudyard Kipling. São Paulo: UNESP, 2005.

ARAGAY, M. (ed.). Books in Motion: Adaptation, Intertextuality, Authorship. Amsterdam: Rodopi, 2006.

AZERÊDO, Genilda. Literatura e Cinema: As Horas de Mrs. Dalloway. Letra Viva (UFPB), João Pessoa, v. 6, n.1, 2005, p. 25-36.

BELLOW, Saul. Letters. Ed. Benjamin Taylor. Nova lorque: Viking Adult (Penguin Books), 2010.

BARBOSA, Heloísa Gonçalves. Procedimentos técnicos da tradução: uma nova proposta. Campinas (SP): Pontes, 1990.

BAKER, Mona (org.). Routledge encyclopedia of translation studies. Londres: Routledge, 1998, p. 5-9.

BASSNETT, Susan. Translation Studies. 3. ed. Londres e Nova lorque: Routledge, 2002.

BELL, Michael Davitt. The Development of American Romance. In: MCKEON, Michael (ed.). Theory of the Novel: a Historical Approach. Baltimore (E.U.A.) e Londres: The Johns Hopkins University Press, 2000, p. 632-56.

BIVAR, Antonio. Bivar na corte de Bloomsburry. São Paulo: A Girafa, 2005.

BONNICl, Thomas. Teoria e crítica literária feminista: conceitos e tendências. Maringá: Eduem, 2007. 
BOTTMANN, Denise. Virginia Woolf traduzida no Brasil. Blog Não Gosto de Plágio. Atualizado em 27 jan. 2013. Disponível em: $<$ naogostodeplagio.blogspot.com.br/2011/08/woolf-no-brasil.html>. Acesso em 12 set. 2013.

BRADBURY, Malcolm. O romance americano moderno. Trad. Bárbara Eliodora. Rio de Janeiro: Jorge Zahar, 1991.

CABRAL, André da Costa; MORAES, Marcos Antonio de. Posta restante: Por falar em cartas... Teresa: revista de literatura brasileira, São Paulo, v.8/9, 2008, p. 430-35.

CAMÕES, Luiz Vaz de. Os Lusíadas (domínio público), 1572. Disponível em $<$ http://lusiadas.gertrudes.com>. Acesso em 12 abr. 2009.

São Paulo: Scipione, 1987.

. Os Lusíadas (domínio público), 1572. Adapt. por Rubem Braga et al.

CARIBÉ, Yuri Jivago Amorim. Panorama da obra de Virginia Woolf no Brasil: traduções e adaptações. Anais do Simpósio Profissão Tradutor, v. 1, n. 1, out. 2011.

CARTMELL, D.; WHELEHAN, I. (eds.) Adaptations: from text to screen, screen to text. Londres: Routledge, 1999.

CHATMAN, S. What novels can do that films can't (and vice-versa). Critical Inquiry, v. 7, n. 1, p. 121-40, 1980.

COHN, Dorrit. Transparent Minds: Narrative Modes for Presenting Consciousness in Fiction. In: MCKEON, Michael (ed.). Theory of the Novel: a Historical Approach. Baltimore (E.U.A.) e Londres: The Johns Hopkins University Press, 2000, p. 493-514.

COMPANHIA DAS LETRAS. 2014. Website. Disponível em: $<$ http://www.companhiadasletras.com.br/autor.php?codigo $=00597$ \#none $>$. Acesso em 15 mai. 2014.

DAVID, Alfred; SIMPSON, James. The Middle Ages. In: The Norton Anthology of English Literature. 8. ed. v. 1. Nova lorque e Londres: W. W. Norton Company, 2006, p. 213-318.

DEFOE, Daniel. Robinson Crusoe. Londres: W. Taylor, 1719. Disponível em: <http://www.planetpublish.com/wp-content/uploads/2011/11/Robinson Crusoe BT.pdf>. Acesso em 22/05/2014.

DINIZ, Thais Flores Nogueira. Literatura e cinema: da semiótica à tradução cultural. Ouro Preto: Editora UFOP, 1999. 
. Literatura e Cinema: tradução, hipertextualidade, reciclagem. Belo Horizonte: Faculdade de Letras da UFMG, 2005.

EAGLESTONE, Robert. Levinas, translation, and ethics. In: BERMAN, Sandra; WOOD, Michael (eds). Nation, Languages and the Ethics of Translation. Princeton and Oxford: Princeton University Press, 2005.

EAGLETON, Terry. The illusions of Post Modernism. Oxford: Blackwell Publishing, 1997.

ECO, Umberto. Quase a mesma coisa: experiências de tradução. Trad. Eliana Aguiar. Rio de Janeiro: Record, 2007.

. O nome da rosa. Trad. Aurora Fornoni Bernardini e Homero Freitas de Andrade. Rio de Janeiro: Record, 2009.

EVEN-ZOHAR, Itamar. The position of tranlated literature within the literary polysystem. In: VENUTI, Lawrence (ed.). The Translation Studies Reader. Nova lorque: Routledge, 2000, p. 192-7.

FAULKNER, William. The sound and the fury. Londres: Jonathan Cape, 1929.

FIELDING, Henry. The History of Tom Jones: a founding. Londres: Andrew Milar, 1749. Disponível em: <http://www.bartleby.com/ebook/adobe/301.pdf>. Disponível em: < Acesso em 22/05/2014.

GALVÃO, W. N.; GOTLIB, N. B. (orgs.) Prezado senhor, prezada senhora: estudos sobre cartas. São Paulo: Companhia das Letras, 2000.

GAMBONE, Philip. Something Inside: Conversations with Gay Fiction Writers. Madison (E.U.A.): University of Wisconsin Press, 1999.

HATTNHER, Álvaro. Literatura, Cinema e outras Arquiteturas Textuais: Algumas Observações sobre Teorias da Adaptação. Itinerários, Araraquara, n. 36, p.35-44, jan./jun. 2013.

HALLEWELL, Laurence. O livro no Brasil: sua história. 2. ed. rev. e am. Trad. Maria da Penha Villalobos et al. São Paulo: EDUSP, 2005.

HUTCHEON, Linda. A poetic of Postmodernism: History, Theory, Fiction. In: MCKEON, Michael (ed.). Theory of the Novel: a Historical Approach. Baltimore (E.U.A.) e Londres: The Johns Hopkins University Press, 2000, p. 830-49.

A theory of adaptation. Londres: Routledge, 2006. 
JAKOBSON, Roman. On linguistic Aspects of Translation (1959). In: VENUTI, Lawrence (ed.). The Translation Studies Reader. Nova lorque: Routledge, 2000, p. 113-25.

JOURNAL OF ADAPTATION IN FILM AND PERFORMANCE. Disponível em: < http://www.intellectbooks.co.uk/journals/view-Journal,id=153>. Acesso em 14 mai. 2014.

JOYCE, James. Ulysses. Paris: Sylvia Beach, 1922.

KRISTEVA, Julia. Desire in Language: a Semiotic Approach to Literature and Art. Trad. Thomas Gora e Alice Jardine. Nova lorque: Columbia University Press, 1980, p. 33-63.

LAMB, Charles e Mary. Lamb’s Tales from Shakespeare. Londres: Longman, 1933. . More tales from Shakespeare. Londres: Longman, 1956.

LEE, Hermione. Virginia Woolf. Londres: Vintage, 1997.

LEFEVERE, André. Literary Theory and Translated Literature. In: Dispositio, v. VII, n. 19-20, 1982a, p. 3-22.

- Mother Courage's Cucumbers: text, system and refraction in a theory of literature (1982b). In: VENUTI, Lawrence (ed.). The Translation Studies Reader. Nova lorque: Routledge, 2000, p. 233-249.

lorque: Routledge, 1992a.

Translation rewriting and the manipulation of literary fame. Nova (ed.). Translation, History, Culture: a sourcebook (1992b). Londres: Routledge, 2003.

LEHMANN, John. Virginia Woolf. Trad. Isabel do Prado. São Paulo: Jorge Zahar, 1989.

LEVY, Heather. The Servants of Desire in Virginia Woolf's Shorter Fiction. Nova lorque: Peter Lang, 2010.

LITERATURE WALES. 2014. Disponível em: <http://www.literaturewales.org/writersof-wales/i/130044/desc/mcneillie-andrew/>. Acesso em 26 mar. 2014.

LUFT, Lya. Perdas e ganhos. Rio de Janeiro: Record, 2004.

LUKÁCS, G. Teoria do Romance. Trad. José M. M. de Macedo. São Paulo: Editora 34, 2000. 
MARCONI, Marina e LAKATOS, Eva Maria. Fundamentos de Metodologia Científica. São Paulo: Atlas, 2007.

MARDER, Herbert. Virginia Woolf: a medida da vida. Trad. Leonardo Fróes. São Paulo: Cosac Naify, 2011.

MCHALE, Brian. Constructing Postmodernism. Londres e Nova lorque: Routledge, 1992.

MCKEON, Michael. The Origins of the English Novel: 1600-1740. Baltimore (E.U.A.): The Johns Hopkins University Press, 1987.

The Colonial and Postcolonial Novel. In: MCKEON, Michael (ed.). Theory of the Novel: a Historical Approach. Baltimore (E.U.A.) e Londres: The Johns Hopkins University Press, 2000, p. 851-8.

MERRY, Bruce. The Literary Diary as a Genre. Revista The Maynooth Review/ Revieú Mhá Nuad. v. 05, n. 01, mai. 1979, p. 03-19. Maynooth (Irlanda): Faculty of Arts, Celtic Studies and Philosophy da National University of Ireland, Maynooth, (NUIM). Disponível em: <http://www.jstor.org/stable/20556925>. Acesso em 22 abr. 2014.

MILTON, J. The Translation of Classic Fiction for Mass Markets: The Case of a Brazilian Book Club, the Clube do Livro. The Translator, v. 7, n. 1, 2001, p. 43-69.

. Between the Cat and the Devil: Adaptation Studies and Translation Studies. Journal of Adaptation in Film and Performance, v. 2, n. 1, 2009, p. 47-64.

Adaptation. In: GAMBIER, Yves; DOORSLAER, Luc van. (Org.). Handbook of Translation Studies. 1 ed. v. 1. Amsterdam: John Benjamins, 2010, p. 3-6.

MONUMENTS MEN FOUNDATION For the Preservation of Art. 2014. Disponível em: $\quad<$ http://www.monumentsmenfoundation.org/the-heroes/the-monumentsmen/popham-anne>. Acesso em 23 dez. 2013.

MORAES, Marcos Antonio de. Epistolografia e crítica genética. Ciência e Cultura (SBPC), v. 1, 2007, p. 30-2.

NEWMARK, Peter (1988). A textbook of translation. Nova lorque: Prentice Hall, 1988.

O'SULLIVAN, Emer. Does Pinocchio have an Italian passport? What is specifically national and what is international about classics fo children's literature? In: LATHEY, G. (ed.). The translation of children's literature: a reader. Clevedon (Inglaterra): Multilingual Matters, 2006. 
ORWELL, George. A life in letters. Londres: Harvill Secker, 2010.

PLATÃO. República. Trad. Pietro Nasseti. São Paulo: Martin Claret, 2005.

PYM, Anthony. The Return to Ethics in Translation Studies. PYM, Anthony (ed.). The Return to Ethics. Special issue. The Translator, n. 7, p. 129-138. Manchester: St Jerome Publishing, 2001.

. Exploring Translation Theories. Nova lorque: Routledge, 2010.

RICHARDSON, Samuel. Pamela. Londres: Mssrs Rivington \& Osborn, 1740. Disponível em: <http://www.gutenberg.org/files/6124/6124-h/6124-h.htm>. Acesso em 22/05/2014.

SANDERS, Julie. Adaptation and apropriation. New York: Routledge, 2006.

SANTOS, Zeloi A. M. dos S. A arte de escrever cartas: a experiência com as fontes. Anais do ANPUH - XXV SIMPÓSIO NACIONAL DE HISTÓRIA - Fortaleza, 2009, pp. 01-08.

SPROLES, Karyn Z. Desiring Women: the partnership of Virginia Woolf and Vita Sackville-West. Toronto: University of Toronto Press, 2006.

SILVA, Carlos Augusto Viana da. Mrs. Dalloway e a reescritura de Virginia Woolf na literatura e no cinema. Salvador (BA), 2007. $242 \mathrm{f}$. Tese de Doutorado defendida no Programa de Pós-graduação em Letras e Linguística - Instituto de Letras, Universidade Federal da Bahia, Salvador, 2007.

STAM, R. Literature and Film: A Guide to Theory and Practice of Film Adaptation. Oxford: Blackwell, 2004.

THE CAMBRIDGE DICTIONARY OF PHILOSOPHY. Ed. Robert Audi. 2. ed. Cambridge: The Cambridge University Press, 1999.

TODD III, William Mills. The Familiar Letter as a Literary Genre in the Age of Pushkin. Evanston (E.U.A): Northwestern University Press, 1999.

TOURY, Gildeon. Descriptive translation studies and beyond. Amsterdam/Filadélfia: John Benjamins, 1995.

. The Nature and Role of Norms in Literary Translation. In: VENUTI, Lawrence (ed.). The Translation Studies Reader. Nova lorque: Routledge, 2000, p. 198-211.

TURNER, William B. A genealogy of Queer Theory. Filadélfia: Temple University Press, 2000. 
VÁSQUEZ-AYORA, Gerardo. Introducción a la tradutologia: curso básico de traducción. Washington: Washington Georgetown University, 1977.

VENUTI, Lawrence. The Translator Invisibility: A History of Translation. Londres: Routledge, 2004.

Adaptation, Translation, Critique. Journal of Visual Culture, abr. 2007, v. 6, n. 1, p. 25-43.

VINAY, J. P. e DARBELNET, J. Stylistique comparée Du français et de l'anglais: Méthode de traduction. ed. rev. e corrigida. Paris: Didier, 1977.

WATT, lan. A ascensão do romance: Estudos sobre Defoe, Richardson e Fielding. Trad. Hildegard Feist. 2 reimp. São Paulo: Companhia das Letras, 1996.

WELLEK, René e WARREN, Austin. Teoria da Literatura. 2. ed. Trad. José Palla e Carmo. São Paulo: Europa-América, 1962.

WOODHOUSE, Reed. Michael Cunningham. Contemporary Gay American Novelists: A Bio-Bibliographical Critical Sourcebook. Ed. Emmanuel S. Nelson. Westport (E.UA.): Greenwood Press, 1993. p. 83-8.

\section{Textos analisados:}

CUNNINGHAM, Michael. The Hours. Nova lorque: Farrar, Straus and Giroux, 1998.

CUNNINGHAM, Michael. As Horas. Trad. Beth Vieira. São Paulo: Companhia das Letras, 1999.

WOOLF, Virginia. Mrs. Dalloway. Londres: Hogarth Press, 1925.

- The Diary of Virginia Woolf. Ed. Anne Olivier Bell e Andrew Mcneillie. v. II; 1920-1924. Londres: Harcourt Brace \& Company, 1980.

- The Letters of Virginia Woolf. Ed. Nigel Nicolson e Joanne

Trautmann. v. VI; 1936-1941. Londres: Harcourt Brace \& Company, 1982. 


\section{Romances de Virginia Woolf citados:}

. The Voyage Out. Londres: Duckworth, 1915.

. Night and day. Londres: Duckworth, 1919.

. Jacob's room. Londres: Hogarth Press, 1922.

. To the lighthouse. Londres: Hogarth Press, 1927.

. Orlando. Londres: Hogarth Press, 1928.

. The Waves. Londres: Hogarth Press, 1931.

. The Years. Londres: Hogarth Press, 1937.

. Between the acts. Londres: Hogarth Press, 1941.

\section{Contos, diários e ensaios críticos de Virginia Woolf:}

. Kew Gardens; Mark on the wall; Modern Fiction. In: Monday or Tuesday. Londres: Hogarth Press, 1921.

. The common reader. v. 1. Londres: Hogarth Press, 1925.

. Orlando: a biograhy. Londres: Hogarth Press, 1928.

. A room of one's own. Londres: Hogarth Press, 1929.

. The common reader. v. 2. Londres: Hogarth Press, 1932.

. Flush: a biography. Londres: Hogarth Press, 1933.

Roger Fry: a biography. Londres: Hogarth Press, 1940.

. The Complete Shorter Fiction of Virginia Woolf. Londres: Hogarth

Press, 1985.

. Mr. Bennet and Mrs. Brown. Série The Hogarth Essays. Londres: Hogarth Press, 1924. In: MCKEON, Michael (ed.). Theory of the Novel: a Historical Approach. Baltimore (E.U.A.) e Londres: The Johns Hopkins University Press, 2000, pp. 745-58. 
2003.

. Carlyle's House and Other Sketches. Londres: Hesperus Press,

\section{Traduções de Virginia Woolf citadas:}

Nova Fronteira, 1980, 2006.

. Mrs. Dalloway. Trad. Mário Quintana. Rio de Janeiro: Globo, 1946; . Mrs. Dalloway. Trad. Claudio Alves Marcondes. São Paulo: Cosac Naify, 2012.

. Mrs. Dalloway. Trad. Denise Bottmann. Porto Alegre: L\&PM, 2012.

. Mrs. Dalloway. Trad. Tomaz Tadeu. Rio de Janeiro: Atlântica,2012.

Fronteira, 2005.

. Um teto todo seu. Trad. Vera Ribeiro. Rio de Janeiro: Nova

. O quarto de Jacob. Trad. Lya Luft. Rio de Janeiro: Nova Fronteira, 1980; São Paulo: Ediouro, 2003; São Paulo: Novo Século, 2008.

de Janeiro: Nova Fronteira, 1978.

- Orlando. Trad. Cecília Meireles. Rio de Janeiro: Globo, 1948; Rio . Orlando. Trad. Laura Alves. São Paulo: Ediouro, 1994.

- Orlando. Trad. Jorio Dauster. São Paulo: Penguin Companhia, 2014.

. O farol. Trad. Luiza Lobo. Rio de Janeiro: Gráfica Record, 1968.

- Passeio ao farol. Trad. Oscar Mendes. Rio de Janeiro: Labor, 1976.

Ao farol. Trad. Denise Bottmann. Porto Alegre: L \& PM, 2013.

Ao farol. Trad. Tomaz Tadeu. São Paulo: Autêntica, 2013.

. Ao farol. Trad. Doris Goettems. São Paulo: Landmark, 2013.

- Noite e dia. Trad. Raul de Sá Barbosa. Rio de Janeiro: Nova Fronteira, 1979; São Paulo: Novo Século, 2008.

Os Diários de Virginia Woolf. Trad. José Antônio Arantes. São

Paulo: Companhia das Letras, 1989. 
Traibunais, 1946.

As Ondas. Trad. Sylvia Azevedo. Rio de Janeiro: Revista dos . As Ondas. Trad. Lya Luft. São Paulo: Novo Século, 2011.

A viagem. Trad. Lya Luft. Rio de Janeiro: Siciliano, 1993; São Paulo: Novo Século, 2011.

. As Ondas. Trad. Lya Luft. Rio de Janeiro: Nova Fronteira, 2004; São Paulo: Novo Século, 2011.

. Entre os atos. Trad. Lya Luft. Rio de Janeiro: Nova Fronteira, 1981; São Paulo: Novo Século, 2008.

- Os anos. Trad. Raul de Sá Barbosa. Rio de Janeiro: Nova Fronteira: 1982, São Paulo: Novo Século, 2011.

A casa de Carlyle e outros esboços. Trad. Carlos tadeu Galvão. Rio de Janeiro: Nova Fronteira, 2003.

2005.

. Contos completos. Trad. Leonardo Fróes, São Paulo: Cosac Naify, . Profissões para mulheres e outros artigos. Trad. Denise Bottmann. Porto Alegre: L\&PM, 2012.

\section{Obras de Michael Cunningham citadas:}

CUNNINGHAM, Michael. $A$ home at the end of the World: a novel. Nova lorque:

Farrar, Straus and Giroux, 1990.

. Flesh and blood. Nova lorque: Farrar, Straus and Giroux, 1995.

\section{Filmes:}

ORLANDO. Filme dirigido e roteirizado por Sally Potter, 1992.

MRS. DALLOWAY. Filme dirigido por Marleen Gorris e roteirizado por Eileen Atkins, 1997.

THE HOURS. Filme da Miramax e Paramount Pictures, dirigido por Stephen Daldry e roteirizado por David Hare, 2002.

Entrevistas, reportagens, depoimentos, resenhas e outros: 
BIVAR, Antonio. Rumo ao final ou a cerimônia do adeus. O Estado de São Paulo, São Paulo, 12 nov. 2011. Sabático, Resenhas, p. S6.

CUNNINGHAM, Michael. Online Newshour, 20 abr. 1999. Entrevistador: Elizabeth Farnsworth. Disponível em: <http://www.pbs.org/newshour/bb/entertainment/janjune99/pulitzer 4-13.html>. Acesso em 12 dez. 2010.

First Love. Pen American Journal, 08 jan. 2007. Depoimento. Disponível em: < http://www.pen.org/nonfiction-essay/first-love $>$. Acesso em 12 dez. 2010.

Em busca da jornada épica das vidas comuns. Depoimento. Trad. Celso M. Paciornik. O Estado de São Paulo, São Paulo, 26 mar. 2011a. Sabático, p. S4-S5. Disponível em: <http://cultura.estadao.com.br/noticias/geral,em-busca-dajornada-epica-das-vidas-comuns-imp-,697458>. Acesso em 10 dez. 2012.

É difícil escapar da influência dela. Entrevistador Rinaldo Gama. Col. Lúcia Guimarães. O Estado de São Paulo, São Paulo, 26 mar. 2011b. Sabático, p. S5. Disponível em: < http://cultura.estadao.com.br/noticias/geral,e-dificil-escaparda-influencia-dela-imp-,697459>. Acesso em 22 mar. 2014.

- Frente a frente com o inaudito. Entrevistador Antonio Gonçalves Filho. O Estado de São Paulo, São Paulo, 20 ago. 2011c. Sabático, p. S4. Disponível em: <http://cultura.estadao.com.br/noticias/geral,frente-a-frente-com-oinaudito-imp-,761203>. Acesso em 10 dez. 2012.

LUFT, Lya. Felicidade é sentir-se bem na própria pele e ter uma relativa serenidade. Entrevista. Revista Vila Cultural, abril, 2008, ed. 47, pp. 4-5.

JATOBÁ, Vinicius. Subterrâneos do universo do desejo. O Estado de São Paulo, São Paulo, 21 abr. 2012. Sabático, p. S5. Disponível em: $<$ http://cultura.estadao.com.br/noticias/geral,subterraneos-do-universo-do-desejoimp-,863770>. Acesso em 22 jan. 2013.

PALESTRA DE LEONARDO FRÓES (em vídeo). Evento Tertúlia Tradutores, São Paulo (SP), SESC Pompéia, 14 dez. 2009. Disponível em < http://www.youtube.com/ watch?v=9m05Gwchjbk> Acesso em 14 set. 2012.

STRODE, Hudson. The Genius of Virginia Woolf: In Her Last Book the English Novelist Again Says the Unsayable. The New York Times, 05 out. 1941. Books. Resenha do romance Between the acts, de Virginia Woolf. Disponível em: $<$ http://www.nytimes.com/books/97/06/08/reviews/woolf-acts.html>. Acesso em 25 mai. 2014.

THE VIRGINIA WOOLF SOCIETY OF GREAT BRITAIN. Disponível em $<$ http://www.virginiawoolfsociety.co.uk>. Acesso em 23 jun. 2014. 
WEBSITE DE MICHAEL CUNNINGHAM. Disponível em: $<$ http://www.michaelcunninghamwriter.com/books/home at the end $>$. Acesso em 24 jun. 2014. 
ANEXO 1 - Fotos de Virginia e Leonard Woolf
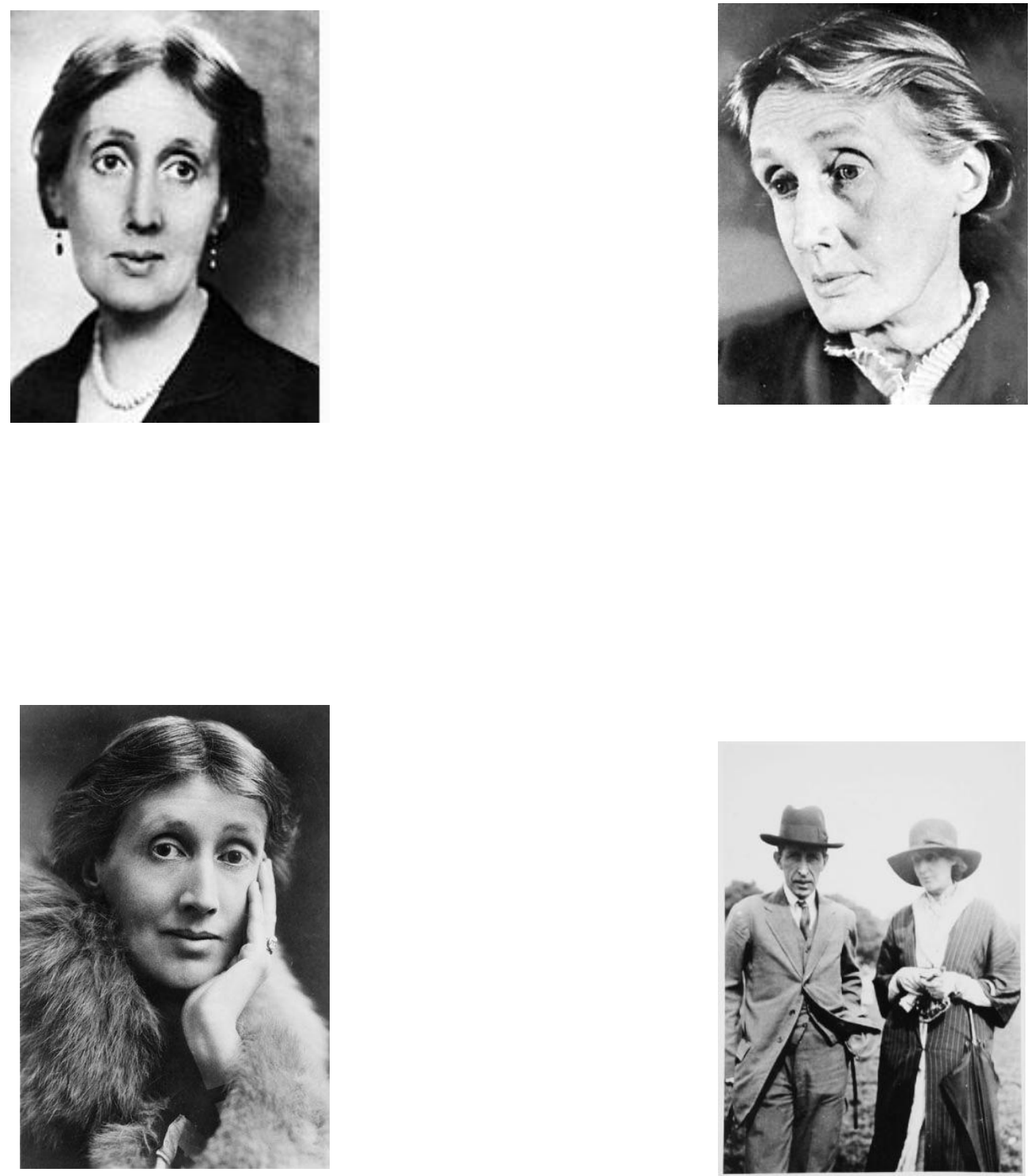
ANEXO 2 - Capas de textos de Virginia Woolf
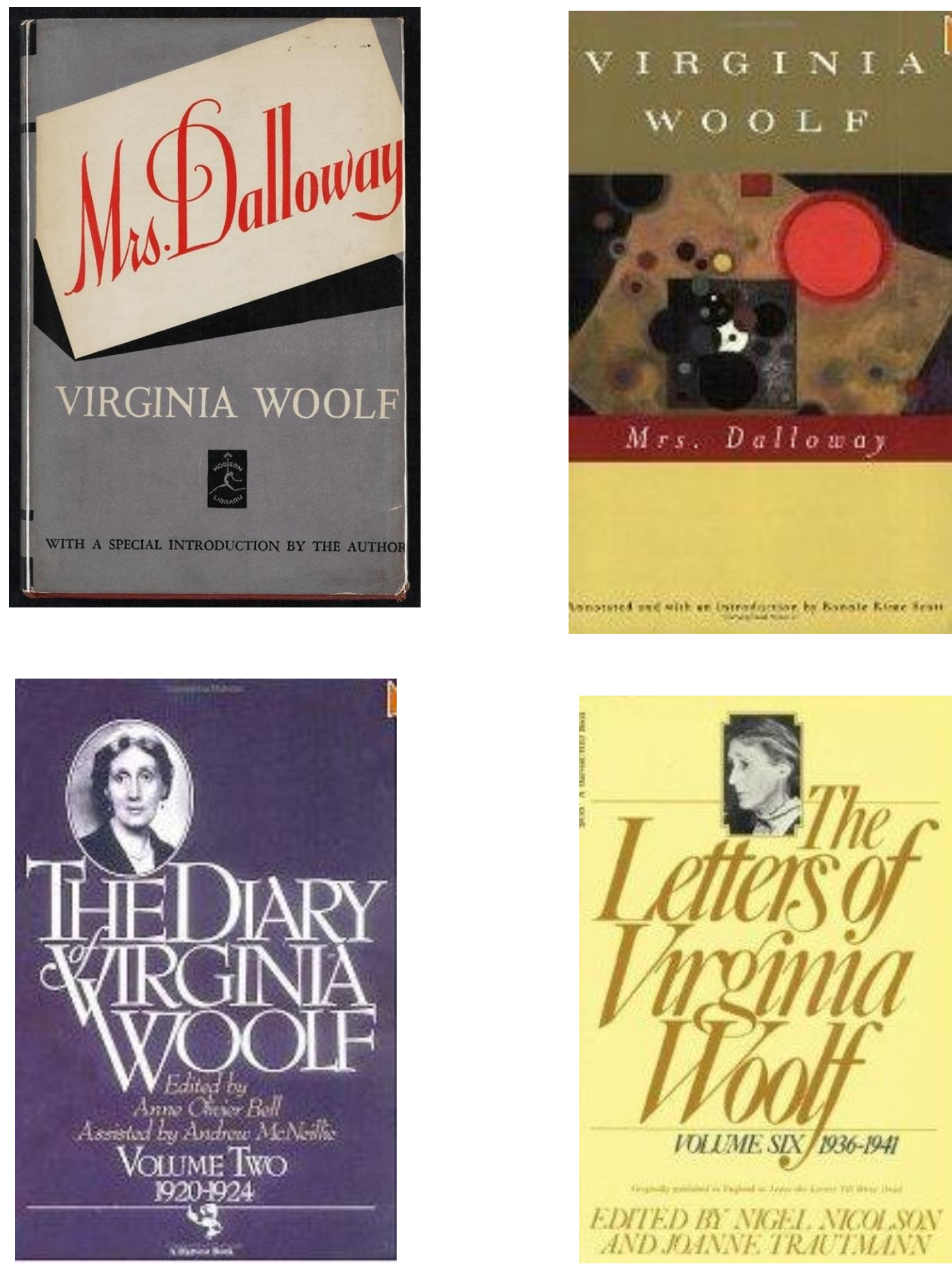
ANEXO 3 - Cunningham e capas de The Hours $(1998,2002)$
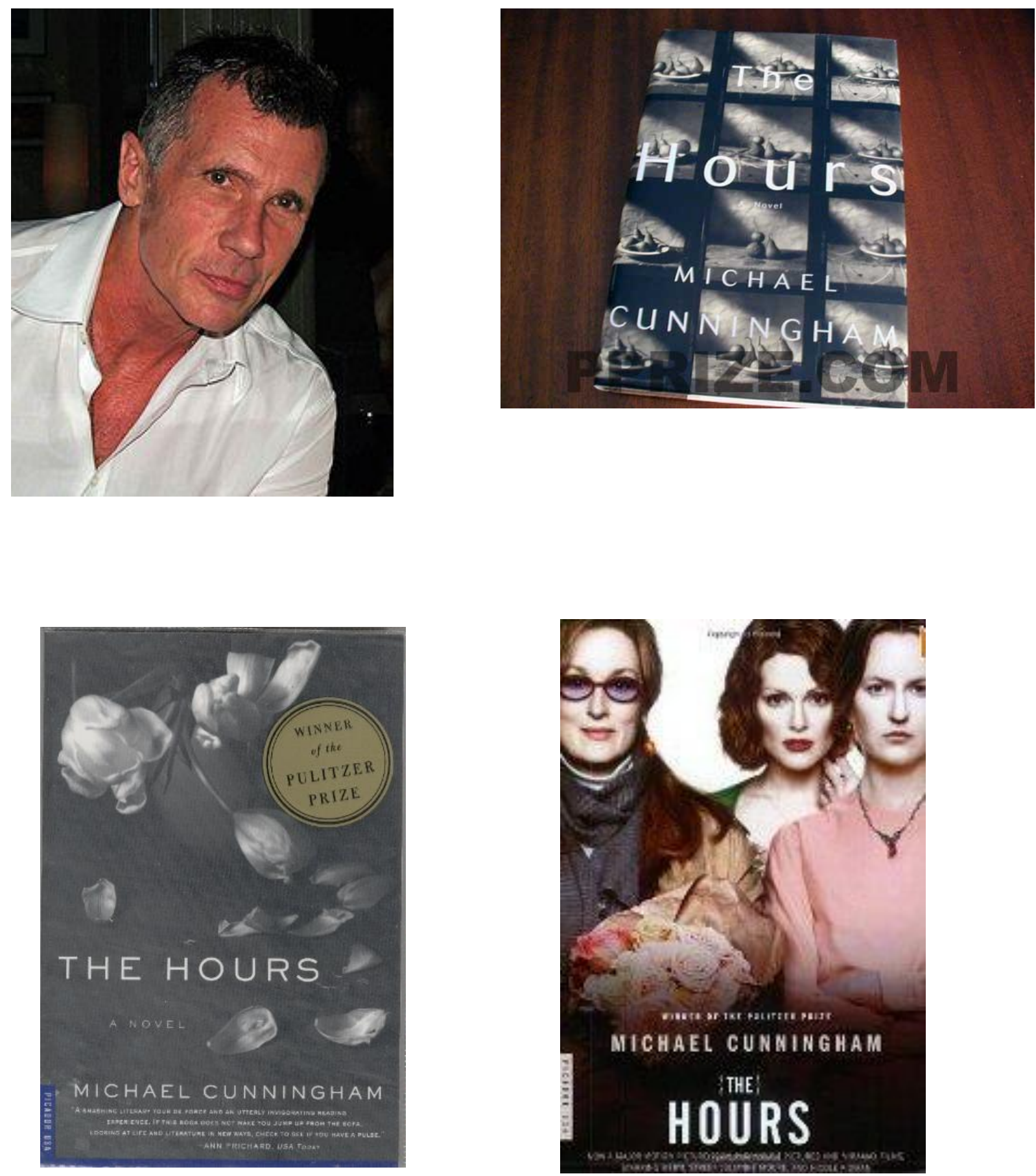